Alma Mater Studiorum - Università di Bologna DEPARTMENT OF ECONOMICS

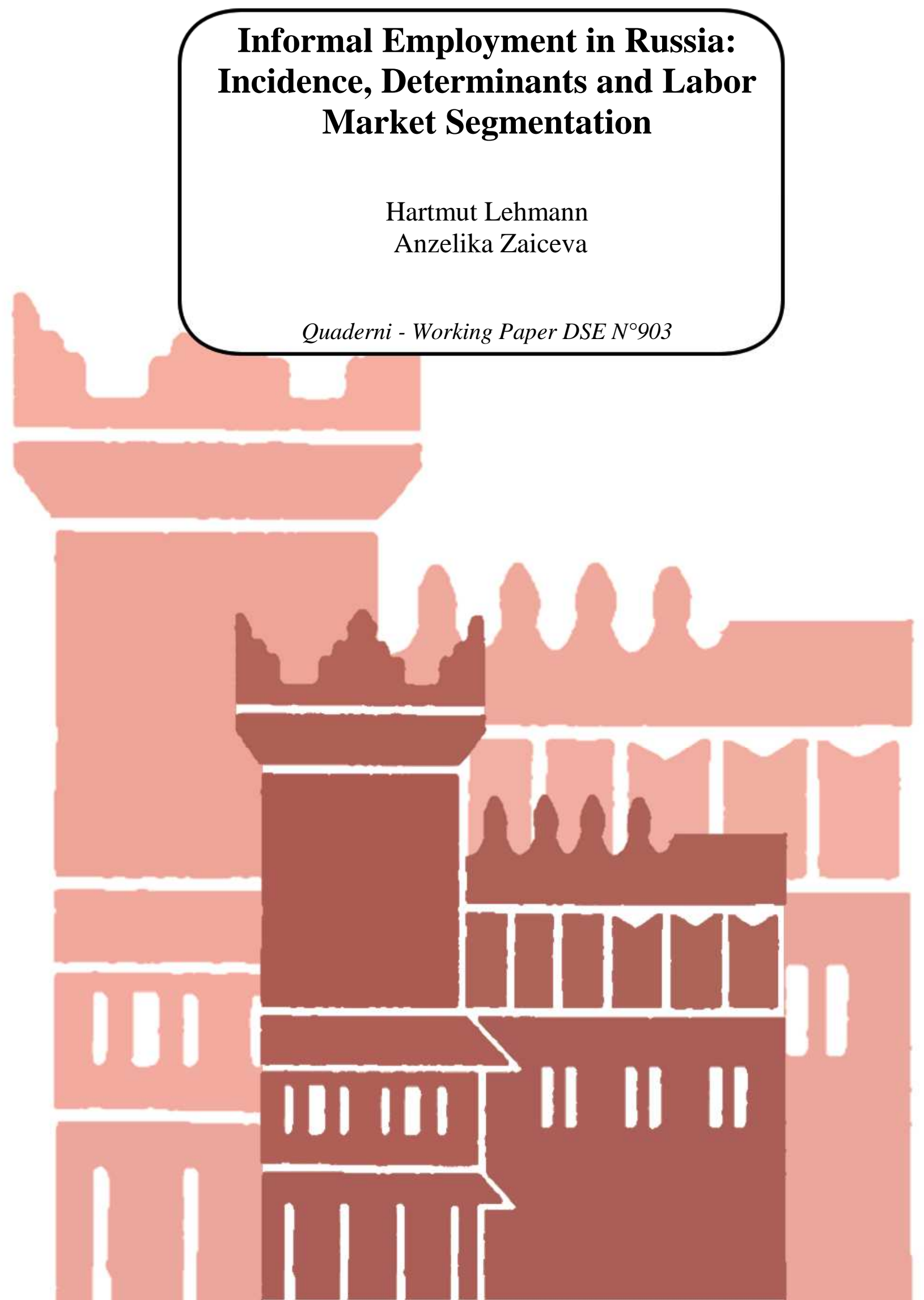




\title{
Informal Employment in Russia: \\ Incidence, Determinants and Labor Market Segmentation*
}

\author{
Hartmut Lehmann (University of Bologna and IZA) \\ Anzelika Zaiceva (University of Modena and Reggio Emilia and IZA)
}

\begin{abstract}
This paper takes stock of informal employment in Russia analyzing its incidence and determinants. Using the regular waves and an informality supplement of the Russian Longitudinal Monitoring Survey (RLMS) it develops several measures of informal employment and demonstrates that the incidence varies widely across the different definitions. We also show that the determinants of informal employment are roughly stable across the different measures: workers who are males, relatively young, unskilled and employed in construction and trade and related services have a higher likelihood to have an informal job. We also take a look at the issue of labor market segmentation along the informal-formal divide by estimating an informal-formal wage gap at the means and across the entire wage distributions. We find only weak evidence for labor market segmentation in Russia when estimating an informal-formal wage gap for salaried workers at the mean. The results of quantile regressions show a wage penalty in the lower half of the distribution and no gap in the upper half for informal employees. In contrast, informal self-employed and entrepreneurs have conditional mean wages that are higher than the mean wages for the formally employed. Across the entire wage distribution, however, we find a negative wage gap in the lowest quartile and a strongly positive wage gap in the highest quartile, pointing to a segmented informal sector with a lower free entry tier and an upper rationed tier.
\end{abstract}

\section{September 2013}

JEL Classification: J31, J40, P23

Key words: Informal employment, transition economies, labor market segmentation, Russia

*The orginal version of this study was a technical background paper for the OECD country report on Russia. The opinions expressed in the paper are those of the authors and should not be attributed to the OECD or to the organizations, with which the authors are affiliated. Comments by participants of the IZA/World Bank conference in Bonn in August 20013 and of the DEEM workshop at the University of Reading in September 2013 were helpful in improving the paper. The authors are also grateful to the Fritz Thyssen Foundation and to the MacArthur Foundation for additional financial support. 


\section{Introduction}

Informality and informal employment pose a major challenge to policy makers in all parts of the world. In this paper we focus on informal employment in Russia. While it is difficult to precisely estimate the size of informality and informal employment, there can be no doubt that in this important transition and emerging economy a substantial part of economic activity is not registered or only partially registered and that many workers enter employment relationships that provide only partial or no protection against unemployment, illness and old age (see Slonimczyk 2012, Gimpelson and Zudina 2011, Kapeliushnikov, 2012). Table 1, based on official Rossstat data, shows the distribution of informal employment relationships across main and secondary jobs and across regions for the years 2003 and 2010. The figures point to a wide variation in the incidence across Russia’s macro-regions. While according to these official data the average share of informal jobs is about 16 percent, this share can be in the low single digits in the high growth and diversified regions of Moscow and Sankt-Petersburg, while it reached 23 percent in 2010 in the relatively poor Southern Region and roughly 38 percent in the North-Caucasus region. At any rate, table 1 demonstrates that informal employment is a wide-spread phenomenon in the Russian labor market.

Informality and informal employment are an important policy issue since there exist equity and efficiency considerations that point to a strong need to vigorously pursue policies that increase the shares of formal economic activity and employment (Lehmann and Tatsiramos 2012).

It is certainly inequitable if part of the workforce and some firms do not pay their taxes since this implies that those who are formal, whether workers or entrepreneurs, have to bear a disproportionate burden in the financing of public goods that are also of benefit to those being economically active without registration. If the informal part of the economy becomes more substantial this can also mean that governments have to raise taxes and contributions on the formal part and thus have to increase the costs of being formal, which in the final analysis can result in 
even more informality and a reduced tax base. Furthermore, often workers in informal jobs are severely exploited and are working under conditions that can be hazardous to their health.

Turning to efficiency, most economists maintain that employment in the formal sector is associated with a greater use of physical capital that requires human capital acquisition on the part of the employed workers, while the informally employed often work with little or no physical capital. Since physical and human capital are very important ingredients of growth, an economy with a relatively large formal sector will, ceteris paribus, grow at a more rapid pace than an economy with a smaller formal sector. In the medium run, policies combating informality and informal employment are thus vital for raising income and welfare of low and middle income countries.

Before one can devise policies to combat informal employment one needs to establish the incidence and the determinants of informal employment and whether we find labor market segmentation across the formal-informal divide. Since all these dimensions might depend on how informal employment is measured, the paper attempts to provide a complete picture of the phenomenon by employing those competing measures of informal employment that are most commonly used in the literature. The paper has the following structure. The next section gives a selective survey of the literature on informal employment in Russia, followed by section III that describes the data and the various measures of informal employment We then discuss the incidence and the determinants of informal employment by estimating probit, linear probability fixed effects and multinomial logit models. Finally, in section $\mathrm{V}$ we analyze the question of labor market segmentation by testing the existence of an informal-formal wage gap in the Russian labor market. 


\section{Pertinent Literature}

The study by Gimpelson and Zudina (2011a) discusses the general trends of informal employment in Russia, emphasizing the difference between employment in the informal sector and informal employment, covering the years 1999 to 2009. Their analysis uses Russian Labor Force Survey (RLFS) data collected by Rossstat and employs a productivity-based definition of informality. They find a clear upward trend in informal employment in the reported period from roughly 8 million in 1999 to about 12 million in 2008, i.e. from roughly 13 to approximately 18 percent of total employment (while when using a definition based on the difference between the overall employment and employment according to enterprise accounting they arrive at a figure of more than 30 percent, Gimpelson and Zudina, 2011b). The authors perform an analysis at the individual and at the regional level. Using multinomial regressions they describe the main determinants of the probability to be informally employed: males, workers with low educational attainment and workers who are employed in construction, retail trade and the hotel and restaurant business are particularly affected. Estimated distributions of the share of informal employment by region point to a rightward shift and a widening of the distributions between 2000 and 2008. Results of fixed effects models that use regional panel data show that in regions with higher GDP per capita but also with a higher unemployment rate the share of dependent informal workers is larger. The first result points to the fact that much of the growth of economic activity that we observe in this period is linked to the growth of informal jobs. The co-movement of the unemployment rate and the share of informal employment can be interpreted that regions with relatively loose labor markets are also characterized by a disproportionally high share of bad jobs. The authors also find that regions with disproportionally high shares of tertiary education, of young and older workers have lower shares of informal employment. While the first finding is very intuitive, the impact of the age structure of the workforce according to the authors can only be explained by the fact that dependent informal employment is heavily concentrated among workers of middle age. As far as the share of informal 
self-employment is concerned, the regional fixed effects regressions only find a positive relationship between this share and the unemployment rate and the share of young workers. The first result points to a complementary relationship between unemployment and informal selfemployment. The second finding seems to imply that informal self-employment is especially widespread among young workers.

Karabchuk and Nikitina (2011) employ the RLMS data to describe informal and occasional employment and define as informally employed those who work in firms with less than 5 employees, those who report not working in an enterprise/organization as well as those who work in an enterprise but do not have an official contract. They report that informal employment has increased somewhat over 2003-2009, reaching its peak in 2004 with $17.6 \%$ and slightly tapering off to $17.2 \%$ in 2009 , when the overall number can be broken down as follows: $3.3 \%$ working in small firms, $8 \%$ not working in an enterprise/organization and 5.5\% working without an official contract. Among the informally employed they find roughly equal shares of female and male workers (although females are more likely to dominate in firms with less than 5 employees while men - to work without a contract or to be self-employed), a higher proportion of workers 26-35 years old, among dependent employees a higher proportion of those 15-25 years old, and a higher share of married persons and service workers (see also Karabchuk, 2012).

The paper by Kapeliushnikov (2012) uses the 2009 supplement to the Russian Longitudinal Monitoring Survey (RLMS) on informality. This supplement contains information that allows the assessment of informality employing various definitions. Kapeliushnikov finds that depending on its definition the incidence of informal employment can vary between slightly more than 10 and almost 25 percent in the Russian labor market and that the social and demographic profile of informal workers dramatically changes when using different definitions. In addition, his econometric exercises demonstrate that the determinants of informality also crucially depend on the definition on which the dependent variable, informal employment, is based. He thus moots that 
estimates of informal employment and its determinants are hardly robust in the Russian case. Our paper discusses varying measures and definitions of informal employment as one of its focal points. However, our paper goes beyond Kapeliushnikov's study in that we do not only use the 2009 supplement on informality but also panel data from the main RLMS survey and retrospective panel data from the 2008 supplement on worker displacement that contains questions on the nature of the employment relationship that workers enter between 2003 and 2008. Hence, we cover more than a cross section and are also able to use models that take into account unobserved heterogeneity in the econometric models. In addition, we also distinguish between the voluntary or involuntary nature of the informal employment relations, which can be done using the main RLMS questionnaire, and analyze determinants of both.

The literature that we have discussed thus far is "static", essentially looking at stocks of employed workers. The papers by Lehmann, Razzolini and Zaiceva (2012) and by Lehmann, Muravyev, Razzolini and Zaiceva (2013) in contrast have a dynamic dimension as they also look at the impact of worker flows on informal employment. Both studies find that those who separate from jobs, whether voluntarily or involuntarily, have a higher probability of finding a subsequent job that is informal or where part of the wage consists of "envelope payments", that is, of undeclared wages. This probability is particularly high for workers who separated involuntarily, i.e. who were displaced, and who have low human capital. The study by Lehmann, Razzolini and Zaiceva (2012) in addition establishes that "informality breeds informality", that is, that workers who separated from an informal job have a far higher likelihood to find a subsequent job that is informal than workers who separated from a formal job.

Slonimczyk (2013) analyzes mobility across different forms of formal and informal employment using transition matrices and a dynamic multinomial logit model employing the RLMS data over the period 2002-2011. He considers as informal entrepreneurs and employees those workers who do not work in firms or organizations, those working at firms without a contract as 
well as those who report undertaking irregular activities. Consistent with the above studies, the authors finds little evidence of entry barriers to the formal sector (with the exception of irregular activities) and concludes that while informal entrepreneurship acts as a stepping-stone toward formal entrepreneurship, informal employees are not more likely than the unemployed to get a formal position. Finally, earnings regressions show a significant gap between formal entrepreneurship which is the best paid option, and other forms of employment.

Informal employment is positively associated with the level of taxation as shown by the macroeconometric evidence in Lehmann and Muravyev (2013) who use country-level panel data in their estimations. Thus lowering the tax wedge might combat informality and the empirical question is about the extent to which tax reforms can relax the disincentives to operate in the formal sector. Slonimczyk (2012) investigates empirically the effect of tax reforms on the incidence of informal employment in Russia using the Russian Longitudinal Monitoring Survey, covering the period 1998-2009. Exploiting the Russian 2001 flat tax reform, which reduced the average tax rates for the personal income tax and the payroll tax affecting mostly individuals in higher income brackets, he estimates the effect of the reform using a differences-in-differences approach. His findings show that the tax reform reduced significantly the incidence of informal employment. The largest reduction is observed on the prevalence of informal irregular activities and for the individuals in the top income brackets who benefited the most from the reform. These results imply that informal employment relationships in the main job and informal self-employment were not really affected in the Russian labor market when the tax wedge was substantially lowered.

Our paper contributes to the literature on informal employment in Russia at least in three ways. First, using unique data we paint a more complete picture of informal employment in the Russian labor market than previously done. Second, as already mentioned, we extend the work of Kapeliushnikov (2012) when establishing the determinants of informal employment by using panel data and taking account of time-invariant unobserved heterogeneity. Third, and most importantly, 
we provide refined evidence of an informal-formal wage gap across the entire wage distributions by employing measures related to salaried workers and measures related to the total of salaried workers, the self-employed and entrepreneurs. This third contribution furnishes value added to the general literature on informal employment since it provides strong empirical evidence for the position of Fields (2004) who stresses the existence of a segmented informal sector, with a free entry lower tier and a rationed upper tier.

\section{Data, Various Measures of Informal Employment and Descriptive Analysis}

\section{III.1 Data}

The analysis uses a database that consists of the panel data of the Russian Longitudinal Monitoring Survey (RLMS) for the years 2003 to 2011 and one special supplement. The supplement is on informality and was administered to the 18th round of the RLMS between September and December 2009. We use the main RLMS panel data of the years 2003 to 2011 and combine them with the new and unique data from the supplement on informality. The supplement focuses on the main job of workers, which in the case of multiple job holding is either the job providing the largest income or the job where the worker deposits his or her labor book. ${ }^{1}$

We also distinguish in our analysis between dependent employees and the self-employed and entrepreneurs. Following Slonimczyk (2012), we consider respondents as selfemployed/entrepreneurs if they report to undertake entrepreneurial activities and to be either owners of firms or self-employed individuals who work on their own account with or without employees.

\footnotetext{
${ }^{1}$ Respondents in the main RLMS and in the displacement supplement are asked to discuss the job that they themselves consider their main job. This can be understood by the respondents in the two ways mentioned in the text.
} 
The final sample, based on the main survey data and the data from the supplement, includes individuals between 15 and 64 years of age, who are not on military duties.

Defining informal employment is a complex issue (see, e.g., Perry et al. 2007). We predominantly focus on the "legalistic" perspective to determine informal employment in this paper, which considers an employment relationship informal if the employer does not register the job in order to avoid the payment of taxes and social security contributions. The Russian labor code stipulates that all employees must sign a written contract and provide their "labor book" to the employer. Oral agreements are explicitly prohibited. Employing the "legalistic" definition, we first formulate a narrow measure of informal employment by focusing on the main job of dependent employees. A broader measure that we also formulate in this study adds second job-holders as well as informal self-employed to dependent informal main job holders.

We also use one variant of the "productive" definition of informal employment, that is, workers being employed in firms with 5 or less employees (10 or less employees) are all considered informal. Also interesting, and thus far little pursued in the literature is informality that arises from “envelope payments”, where workers who are formally employed get at least part of their income as undeclared wages.

The main RLMS data survey instrument contains questions that allow the identification of workers who have informal employment relationships. Dependent employees are asked whether they are officially registered at their job, i.e. whether they are on a "work roster, work agreement or contract?” A positive response to this question is interpreted as a formal employment relationship. Those workers who say no to this question are considered to be in an informal employment relationship. For those who are determined to be in such a relationship we can also establish 
whether they entered it involuntarily or voluntarily. ${ }^{2}$ A broader measure adds second job-holders (employees without a formal contract/agreement) as well as informal self-employed. As in Slonimczyk (2012) self-employed are considered informal if their activity is not registered with the authorities (i.e. report to not working in an enterprise/organization) or if they respond that they are not covered officially by a work agreement or contract. From the main data set we can also recover the percentage of a worker's salary that is paid officially, that is on which taxes and contributions are paid, thus indirectly establishing the incidence and extent of unofficial wage payments or socalled “envelope payments.” In addition, we also define informal as those who are either informal dependent employees because they have no work contract and those who reply that they do not work in an enterprise/organization, without additional restrictions regarding self-employment. Finally, in the RLMS there is a list of 11 benefits that are provided to a worker. The absence of the mandatory three benefits, i.e., paid vacations, paid sick leave and maternity leave, is considered an indicator of informality. This information is available for dependent employees only and for both the main and the second job.

The 2009 supplement on informality allows us to establish dependent workers who have an oral contract in 2009, which we take as an additional measure of an informal employment relationship. The informality supplement also allows us to get at the issue of informal employment from many additional angles, which we discuss in the next section.

\footnotetext{
${ }^{2}$ Respondents are asked whether (1) the employer did not want a registration of the job, (2) the respondent did not want to register, or (3) both employer and respondent did not want to register. Respondents giving answers (2) or (3) are deemed to be voluntarily in informal jobs.
} 


\section{III.2 Various Measures of Informal Employment}

Figures 1-4 plot the incidence of informal employment and the non-employment rate ${ }^{3}$ for the period 2003 to 2011, relying on measures derived from the main RLMS data. Until 2008, the year of the financial crisis, non-employment shows a clear downward trend from 38 to roughly 33 percent, with a reversal after the crisis year and a slight rise to about 34 percent in 2011. Using non-registration (no contract) in the main job (panel a of figure 1) and non-registration of main or secondary job or informal self-employment (panel b of figure 1) as our measures of informal employment, informal employment rises between 2003 and 2006 and falls between 2009 and 2011. Thus for most of the period informal employment and non-employment are substitutes and not complements. This seems also to be the case for the most part of the informality definition based on dependent employment and not working in an enterprise/organization either in the main job (panel a of figure 2) or the main or the secondary job (panel b of figure 2).

When we use firm size as our criterion for informal employment, for most years informal employment tracks non-employment. This is especially so for firm size less than 5 as inspection of panel a of figure 3 shows. Thus when firm size underlies our measure of informal employment, this labor market state seems to behave complementary to non-employment. Finally, figure 4 shows one additional measure of informality based on benefits. In the RLMS there is a list of 11 benefits that are provided to a worker. The absence of the three mandatory benefits, i.e., paid vacations, paid sick leave and maternity leave, is an additional indicator of informality that we contrast with nonemployment. This information is available for dependent employees only and for both the main job (panel a of figure 4) and the second job (panel b of figure 4). As with firm size, this informality measure seems to be complementary to non-employment.

\footnotetext{
3 Since the border between unemployment and inactivity is rather blurred in the Russian labor market and unemployment benefits are below the subsistence minimum if available at all, we report the non-employment rate and not the unemployment rate.
} 
Table 2 presents different measures of informal employment overall and with the data sliced by gender, education and immigrant status. The first measure is narrow and comprises only informal dependent employment at the main job, while the second measure is more general, including informal employees as main job holders, informal workers in a secondary job and all informal self-employed. The third measure takes firm size as the defining criterion. The fourth measure is the share of all workers who receive all or part of their wages as "envelope payments", that is where all or part of their wages are not taxed. Many of the workers with "envelope payments” can work in the formal sector and can have a formal contract. The fifth definition of informal employment included employees without a contract and those who do not work in an enterprise/organization in the main or secondary job. The final definition is based on the nonavailability of the three mandatory benefits.

Overall, as expected, using different measures of informality has different quantitative implications for its incidence. While the lowest number is given by dependent employees without a work/contract agreement (around 6 percent in 2011 relative to all employees), the highest numbers emerge if we use definitions based on envelope payments (around 19 percent in 2011) and the broadest employment-based definition that includes informal employees as well as those who do not work in an enterprise/organization (around 17 percent in 2011). Another interesting fact that emerges both form Table 2 and figures 1-4 is that for all measures apart for the one based on benefits, informality is larger in the end of the period than in the beginning (in some cases the difference is rather small though), which is consistent with a growth of informal employment during the 2000s reported by other studies. Finally, as figures 1-4 show there are important dynamics throughout the whole period, since informality has been increasing in the beginning of the period, mostly decreasing thereafter until 2008, the year of the economic crisis, increasing again right after, and there seems to be some downward tendency most recently for some of the measures. Overall, our broad definition of informality that includes both informal employees and those who report not 
working in an enterprise or organization suggests that the post-2008 level of informality is larger than the pre-2008 one.

Looking across gender, educational attainment and migration status, we see a clear ranking of the measures of informal employment. Workers with "envelope payments" and informal employees together with those not working in an enterprise/organization have clearly the highest incidence, followed by the broad measure based on informal employment and on benefits . The definition using firm size produces the next highest incidence of informal employment for the most part, although at times this measure gives a lower share of informal workers than the measure of informal main job holders (dependent employees) who in general have the lowest incidence.

In the years 2007 and 2011 female workers have a statistically significant lower incidence of informal employment. So, like in other transition economies (see Lehmann and Pignatti 2007) and unlike in developing countries (see, e.g., Perry et al. 2007) female workers are less likely to have an informal job than men. However, when the criterion of firm size is used women seem to have a higher incidence of informal employment. Of course, one can interpret this last result simply as pointing to the fact that the employment of female workers tends to be concentrated in smaller firms. Thus when one contrasts this result with the lower incidence of informal employment for women using the other three measures the potential weakness of the firm size measure becomes apparent.

Educational attainment has a significant impact on the rate of informal employment as the central panels of table 2 demonstrate. In 2011 apart from the measure based on firm size workers with secondary education have a lower rate than workers with only primary education. In addition, in all years workers with higher education have a statistically significant lower incidence of informal employment than workers with secondary education no matter which measure of informal employment is used. Migrant status, on the other hand, is particularly relevant in 2011: as the last panel of table 2 shows, migrants are more involved in informal employment relationships independent of the underlying measure. 
When slicing the data by gender, educational attainment and migration status, in general statistically significant difference between the groups with the expected signs are valid for all measures used. The one measure where this not always holds is firm size. The correlations between the different informality measures, calculated over the years 2003 to 2011 (Table 3a) and 20092011, for which the wage measure is available (Table 3b), confirm this weak correspondence of the firm size measure with the other measures. While other measures are highly correlated, the measure with firm size less than 5 employees has a very low correlation with the other measures. Since researchers sometimes use firm size equal to or less than 10 employees as a measure of informal employment we have included this measure in the table. It is only highly correlated with the other firm size measure. Among informally employed individuals classified by the above four definitions, more than 20 percent work in firms with less than 5 employees and over 12 percent have an informal wage share. In the descriptive and econometric analysis that we undertake in the paper we rely above all on the first two measures and include the firm size measures only for comparative purpose since they show the lowest correlations and are thus covering rather different subsets of workers.

Before we turn to the descriptive analysis we discuss the wide variation in the incidence of informal employment that we can additionally elicit from the rich information contained in the 2009 main data set of the RLMS and its 2009 informality supplement. The first panel of table 4 presents measures of informal employment based on responses extracted from the main questionnaire. The first cell shows the lowest incidence in the entire table, which relates to dependent employees without a work agreement or contract among all dependent employees. The next entry in the first panel puts together all dependent employees in the main or secondary job without contract as well as informal self-employed; this group reaches an incidence of about 10 percent relative to the employed population. Finally informal employees defined as workers receiving all or part of their wages as "envelope payments” amount to about 18 percent in 2009. Among the self-employed, a 
whopping 73 percent are informal according to the most encompassing definition of informal selfemployment.

Extracting information about contract type from responses in the supplement, we use an oral agreement of dependent workers as an indication of informal employment. In this case, the incidence of informal employment among dependent workers is about 4 percentage points higher relative to the measure that uses lack of an official contract elicited from the main questionnaire (cf. $11.17 \%$ in panel 2 to $6.91 \%$ in panel 1). Dependent employees in the main and secondary jobs with an oral agreement plus non-registered self-employed make up a slightly higher share than the corresponding measure from the main questionnaire. Questions on whether employers or the selfemployed pay social security contributions on the wage allow us to arrive at an additional definition of informal employment. ${ }^{4}$ Thus defined, as the entries in the next cells of the central panel indicate, slightly less than 20 percent of all dependent employees are informal. If we consider dependent employees and firm-owners who do not pay social security contributions, this definition also implies that roughly 20 percent of overall employment is informal. However, the definition from the supplement (business is not registered) gives a much lower estimate of informal selfemployment among all self-employed than the definition from the main data (cf. $44.77 \%$ to 73.02\%), while a bit more than half of all self-employed do not pay contributions.

We develop a final and non-standard definition of informal dependent employment by taking into consideration the attitudes of employers versus labor laws and work agreements available in the 2009 supplement. Not respecting labor laws and work agreements one hundred percent will affect the security of jobs to some degree and can introduce an element of informality into jobs. On the measure of not respecting one hundred percent labor laws we arrive at a share of informal dependent employment of roughly 45 percent, while the informality rate based on not respecting one hundred percent work agreements reaches about 40 percent. While we will not

\footnotetext{
${ }^{4}$ We define employment as informal if the employer or the self-employed does not pay, at least in part, the social security contributions commensurate with an employee's or a self-employed person's wage.
} 
pursue this definition of informal employment any more in the paper, we find it worthwhile to highlight the two statistics based on this non-standard definition as they can demonstrate the multifaceted nature of informal employment relationships in the Russian labor market.

In Table 5 we present correlations between some of the more standard measures of informal employment coming from the main data set and from the supplementary data in 2009. What is particularly important is the high correlation between measures that rely on non-registration of the job, on one hand, and on oral type of contract, on the other hand. The high correlation between "job without contract” and "oral contract” thus implies that it is legitimate to use these two measures of informal employment interchangeably. It is also noteworthy that only the measure of informality based on "envelope payments" has a relatively low correlation with the other measures while the measure derived from responses regarding the unwillingness of employer to pay social security contributions shows a relatively high correlation with all other measures.

\section{III.3 Descriptive analysis}

We slice the data by sector and occupation and show the shares of informal employment using three "legalistic" definitions in figures 5 and 6, and the firm size definitions in figures 7 and 8. ${ }^{5}$ Figure 5 demonstrates the large variation in the incidence of informal employment by sector, with construction and trade and related services showing by far the largest shares of informal employment. In addition, in light and food industry, transport, agriculture and in other sector we also find a relatively large incidence of informal employment (panels b and c of figure 5). Service workers, workers in crafts and related trades as well as unskilled workers have far higher shares of informal employment in the main job than other occupations (panel a of figure 6). When we add non-registered secondary jobs and self-employment, skilled agricultural and fishery workers as well as legislators, senior managers and officials are additional occupational categories with a high

\footnotetext{
${ }^{5}$ The figures showing occupations need to be interpreted with caution, since the number of observations for some occupations is very small .
} 
incidence of informal employment, as panel b of figure 6 attests. Thus, these two groups seem to be particularly involved in unofficial work when they have a secondary job or are self-employed. When we use the answer "not in an enterprise/organization at the main or second job" to get at informal self-employment and entrepreneurship (panel c) we get the same dominant occupations as in panel $b$.

The sector trade and related services has by far the highest incidence of informal employment when we use firm size as our measure (see panels a and b of figure 7). Apart from other sector we now also find public administration and science and culture exhibiting relatively high shares of informal employment. These relative magnitudes strike us as an indication that firm size might not be a good measure for informal employment. What the bottom panel of figure 7 (firm size equal to 10 or less) seems to indicate is that some workers in public administration and science and culture are employed in small work units. It is strikes us as rather unlikely that, e.g., 25 percent of workers in public administration are informally employed. The same caveat seems to apply when we look at informal employment by occupation using firm size as our criterion (see figure 8). While we find it reasonable that service workers and skilled agricultural and fishery workers have a high incidence of informal employment, it is hard to believe that legislators, senior managers and officials have an incidence that is twice as large as that of unskilled workers (see panel b of figure 8). Hence, while the measure using firm size less than 5 might be acceptable when trying to capture a large chunk of informal employment, the measure based on firm size less than 10 strikes us in the final analysis as inappropriate. Consequently, our econometric work is confined to the smaller metric of firm size whenever this criterion is chosen to define informal employment.

We conclude our descriptive analysis by showing the distributions along the informal-formal divide of age, gender, marital status, regional location, educational attainment, migration status, occupation and industry for the years 2003 and 2011 (table A1 in the appendix). For the first four characteristics we have a different number of non-empty cells than for educational attainment, 
which in turn has a different number of non-empty cells than migrations status. There is also a different number of empty cells for occupation and industry. We thus indicate the number of observations for each category and these five groups of characteristics separately. In addition, we indicate significance when the characteristic with informal employment has a significantly different share from the same characteristic that prevails with formal employment. Informal employment in this table refers to dependent employees without a work contract or agreement.

In both years young workers have a particularly high incidence of informal employment, while those above 40 years of age are less likely to be informally employed by a wide margin. Among the informally employed we find a majority of male workers. This larger share is statistically significant and in line with findings about other transition countries as already mentioned. While the majority of both formally and informally employed workers is married, this share is substantially lower when the job is informal. Workers in Moscow and St. Petersburg and in the Eastern region have a higher, workers in Central Volga and Southern regions a substantially lower incidence of dependent informal employment according to this definition. Residing in a regional center increases the likelihood of being informally employed whilst this likelihood is significantly lower when one resides in a village.

Unsurprisingly, workers with only primary education have a higher, workers with higher education a substantially lower share of informal jobs. Looking at all immigrants in 2003, we find a significantly lower incidence of informal employment. When disaggregating immigrants by region of origin, we establish that in 2011 immigrants from the Caucasus and Central Asia have a higher probability of being in an informal job than their non-migrant counterparts. Overall, though, immigration does not seem to be strongly correlated with informal employment in the Russian labor market.

In both years, service workers, workers in crafts and related trades and unskilled workers are far more represented in informal employment than in formal work. Occupations that require 
high skills are, on the other hand, relatively scarce among the informally employed. Turning to sectors, the very high shares of workers informally employed in construction and trade and related services are striking, whilst virtually all other sectors have only tiny shares of informally employed.

\section{Determinants of informal employment}

\section{IV.1 Determinants of overall informal employment using various measures}

Which factors are the main determinants of informal employment? Are the identified determinants stable across a spectrum of different definitions of informal employment? Table 6 that summarizes

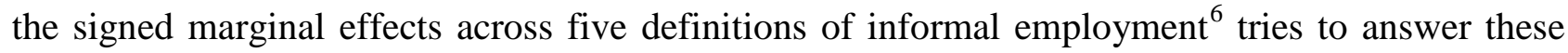
questions. The first 5 demographic factors show some interesting patterns. Informal employment decreases in age when we take the four "legalistic" measures, but increases in age when we use the firm-size measure. On this last measure male workers are less likely to be informally employed, while we find a higher probability of informal employment for male workers in the case of the first four measures. Being married and more educated decreases the likelihood of being informally employed no matter which measure of informal employment is used.

As far as location is concerned it is noteworthy that apart from the East dependent employees in Moscow and St. Petersburg have a higher probability to be informal than their counterparts in the rest of the country. When we extend the measure to informal self-employed and entrepreneurs the relative incidence is reversed for virtually all regions. It is also striking that residing in a village lowers the probability of being informally employed for the first four measures while this probability is increased if we use the criterion of firm size instead.

Industry affiliation and occupation show the same relative patterns that were shown in figures 5-8. Holding other observable factors constant, relative to workers being employed in light

\footnotetext{
${ }^{6}$ Table 6 is based on the complete results of probit regressions shown in tables A2-A6 in the appendix.
} 
and food industry workers employed in the industries construction and trade and related services as well as other industry have a higher incidence of informality no matter which measure is used. When we use the most encompassing measure of informal employees and selfemployed/entrepreneurs (measure 3) transport and communication becomes an industry with a higher incidence of informality. Relative to unskilled workers most other occupations have a lower incidence of informal employment as long as the first four measures are used. This does not hold for legislators, senior managers, officials when secondary jobs are included (measure 2) which points to informal work in secondary jobs for this group of professionals. Also, skilled agricultural and fishery workers are more involved in informal secondary jobs and as self-employed. Using the most encompassing measure (measure 3), service workers have a higher incidence of informal employment than unskilled workers.

When we compare the marginal effects of occupation using the first four measures and the firm size measure it becomes clear why firm size might not be a good criterion when defining informal employment. Using firm size, virtually all occupations have a higher incidence of informal employment than unskilled workers. This result might be explained by the fact that in an emerging transition economy like Russia's the majority of unskilled workers in case they are employed have jobs in large firms. At least when it comes to occupations firm size is not a criterion that allows us to tell anything about the distribution of formal and informal jobs.

An important upshot of the results presented in table 6 is that the affirmation by Kapeliushnikov (2012) of a non-robust picture regarding the determinants of informal employment needs to be qualified. While the measure based on firm size does indeed produce a different set of determinants than the other measures, when we concentrate on the first four measures we find for the most part a broad congruence regarding the drivers of informal employment; thus one can speak of a roughly robust picture with respect to the determination of informal employment when considering these first four measures. 


\section{IV.2 Determinants of informal employment by employment state}

In most labor markets, there are some workers who are forced to take an informal job, while there are others who deliberately choose to take such a job (for Latin American labor markets, see Perry et al. 2007). It is, therefore, insightful to divide informal employment into two states, involuntary and voluntary informal employment and estimate their determinants. In table 7 we combine dependent employees and the self-employed and assume that a self-employed who has an informal job has taken it on voluntarily. When dependent employees (alone or together with the employer) do not want to register their job we also assume that they choose this job voluntarily. So, these two groups of workers make up the state of voluntary informal employment. In contrast, when only the employer does not want to register the job, workers are involuntary informal. We thus have three employment states in table 7, involuntary informal, voluntary informal and formal employment, and three specifications, one without immigrant, one with immigrants in general and one with immigrants grouped according to their regions of origin.

We focus our discussion on columns $7-9$, that is on the specification with immigrants identified by region of origin, since the marginal effects with the more parsimonious models are virtually identical and the marginal effects of the immigrants are particularly insightful when estimated for different groups of immigrants. ${ }^{7}$ Age affects informal employment negatively, whether involuntary or voluntary, although this effect is rather small. Also, male workers have a third of a percentage point higher probability to be in either an involuntary or voluntary informal job, while being married depresses this probability by roughly the same small amount. Particularly noteworthy is the different impact of higher education on the informal employment state: higher educational attainment lowers the probability of being involuntarily in an informal job by a lot more than being voluntarily in an informal job. So, workers with higher educational attainment are

\footnotetext{
${ }^{7}$ Note that by construction the three marginal effects sum to zero, so when, e.g., the marginal effects for both types of informal employment are negative the marginal effect for formal employment has to be positive. Thus it suffices to discuss the marginal effect for the two informal employment states.
} 
predominantly in an informal job at their own volition, a result confirmed also by Lehmann, Razzolini and Zaiceva (2012). Relative to residing in Moscow or St. Petersburg, residence in the Eastern region increases the likelihood to find oneself in an informal job involuntarily by half a percentage point, while residence in the Central-Volga and the Southern regions is associated with a lower probability of choosing an informal job voluntarily. Regarding immigrants, it is striking that immigrants coming from other parts of the former Soviet Union than the Caucasus and Central Asia are especially strongly afflicted with involuntary informal employment.

Working in construction, trade and related services as well as other industry implies a probability of working informally that is between one half and one percentage point higher than working in the default sector, light and food industry. In the case of other industry this higher probability is confined to voluntary informal employment, while the marginal effects do not differ across the voluntary-involuntary divide for the other two sectors. Relative to unskilled workers all shown occupations have a lower propensity to be engaged in informal employment. This lower propensity seems particularly strong for involuntary informal employment, essentially stating that in the main job it is above all unskilled workers who are employed in informal jobs involuntarily.

Self-employed workers might behave differently from dependent employees when selecting an employment state. We, therefore, divide employment in five states in table 8: involuntary informal dependent employment, voluntary informal dependent employment, informal selfemployment, formal self-employment and formal dependent employment. As already mentioned, we assume informal self-employment to be voluntary. While males have a higher incidence of both dependent informal employment and informal self-employment, the marginal effects of age, marital status and educational attainment have opposite signs when we distinguish between dependent and self-employment: these factors increase the likelihood to engage in informal self-employed activities, but decrease it for both voluntary and involuntary informal dependent employment. While being an immigrant from the Caucasus or Central Asia raises the likelihood of informal self- 
employment, immigrants from other parts of the former Soviet Union do not seem to be more involved in self-employment than natives, but seem to have a particularly high incidence of involuntary informal dependent employment. Working in construction and in trade and related services raises the probability of being employed in both types of informal dependent employment as well as in both types of self-employment, while a worker in other industry has a particularly high incidence of informal self-employment. Finally, compared to unskilled workers virtually all occupations seem to have a higher propensity to be engaged in informal self-employment and a lower incidence of working in voluntary and involuntary informal dependent employment.

\section{IV.3 Risk attitudes and informal employment}

There is a growing empirical literature that looks at the impact of risk attitudes on economic behavior at the micro level. Regarding informality, we moot that workers that have a higher tendency to take risks are more likely to engage in informal employment. In order to test this supposition we take advantage of the 2009 supplement on informality that contains a module on risk attitudes in general and risk attitudes in different life domains. Figures 9 and 10 show the scale of risk attitudes in general and of risk attitudes in financial matters: the scales go from 0 (“completely unwilling to take risks”) to 10 (“completely willing to take risks”). ${ }^{8}$

Inspection of the two figures seems to indicate that relatively risk averse workers tend to prefer formal employment. It is also striking that persons who are more inclined to take risks have an especially high incidence of self-employment. Also, most of the mass for informal employees can be found in the upper part of the distribution, that is from 5 to 10. So, informal employment and more risk loving behavior seem to be positively associated. Since we use a cross section here we

\footnotetext{
${ }^{8}$ These risk measures have been experimentally validated in the context of the German Socioeconomic Panel (GSOEP), where they have been introduced first, but intensive analysis of risk attitudes in Ukraine by Dohmen, Khamis and Lehmann (2013) seem to indicate that in this transition country the drivers of risk attitudes are virtually identical to those in Germany. We, therefore, think that these measures of risk attitudes have some validity in Russia.
} 
cannot establish whether we deal here with a correlation or a causal effect. However, the work undertaken in Dohmen, Khamis and Lehmann (2013) shows that risk attitudes have a very long gestation period and that it is unlikely that short periods of labor market experience cause risk attitudes. Rather, risk attitudes have a causal impact on the selection of labor market states and the regressions that we present in table 9 in our opinion can be given a causal interpretation as far as the risk measures are concerned.

We look at two measures of risk attitudes, the measure already presented that has a scale from 0 to 10 and a risk indicator, which takes the value 1 if the risk measure takes a number between 6 and 10 and takes the value 0 otherwise. These two measures are used for both the general and the financial domain. The estimates with the general risk measure and a full set of controls (column 2) show that an increase of the risk measure by one unit will raise the probability of being informally employed by one fifth of a percentage point. The same result holds when risk attitudes are proxied with the risk measure in the financial domain. Persons who are risk loving, that is who find themselves on the scale between 6 and 10, have a probability that is 1.3 percentage points higher in case of the general risk indicator and 2.2 percentage points higher in the case of the financial indicator to find themselves in informal employment than persons who are relatively risk averse (see columns 4 and 8). These percentage point increases are large if one considers that in 2009 the observed incidence of informal employment in the main job was slightly below 7 percent (see panel a of figure 1). Thus risk attitudes have to be thought of as an important predictor of employment along the informal-formal divide in the Russian labor market.

\section{Labor market segmentation in Russia: estimating informal-formal wage gaps}

The scarce literature on informality in transition countries analyzes the generally contentious issue of whether labor markets are segmented and workers are prevented from entering the formal sector, 
as put forth in an early seminal paper by Harris and Todaro (1970), or whether labor markets are integrated and most workers choose voluntarily the informal sector (see, e.g., De Soto 1990 and Maloney 2004). For Bosnia and Herzegovina Krstic and Sanfey (2007) find segmentation as do Bernabè and Stampini (2008) for Georgia. Lehmann and Pignatti (2007), on the other hand get mixed results for the Ukrainian labor market: while they establish segmentation for dependent employees, they find a two-tier informal self-employment sector, where the lower tier reflects an integrated labor market, i.e. anyone can enter informal activities, while the more remunerative upper tier is rationed, that is, workers are blocked from freely entering this part of informal selfemployment. Here we deal with the issue of labor market segmentation in the Russian context by analyzing the question whether there exists an informal-formal wage gap at the means and across the entire wage distributions.

The OLS and Fixed Effects wage regressions presented in tables 10 and A7 use wages in the last 30 days or in the last 12 months in the main job as a base to calculate hourly wages. Since the fixed effects regressions rely exclusively on within changes, these regressions can only use those few observations that involve a change in employment status, i.e. a change from formal to informal employment or vice versa. It is, therefore, not surprising that the fixed effects estimates are less precise than the OLS estimates. Since the results of table A7 are in the same ballpark as those of table 10, we focus on the latter results.

Turning to the results, the OLS estimates show an informal-formal wage gap of between 7.5 and 12.2 percent. When we take into account time-invariant heterogeneous factors these numbers drop dramatically, with the maximum gap being reduced to 2.8 percent. While this estimate is not statistically significant at conventional levels it has the same sign as the OLS estimates and it is nearly significant at the $10 \%$ level. Hence, there is some weak evidence of labor market segmentation along the informal-formal divide in the Russian labor market. 
When we add informal self-employed and entrepreneurs to the regression (table 11) we can clearly see that self-employed and entrepreneurs do not encounter wage penalties on average but actually a wage premium when they work informally. Controlling for region, year, sector and occupation in addition to the shown controls they earn a premium of roughly 4 percent when unobserved heterogeneity is accounted for. Note that the wage penalty for informal employees is completely wiped out which seems to indicate that there is no informal-formal divide in the Russian labor market.

When we perform quantile regressions (table 12) we do find segmentation, which is, however, within the informal sector. In the lower part of the wage distribution informal employees as well as informal self-employed and entrepreneurs face penalties. For dependent employees these penalties disappear in the upper part of the wage distribution, which we can take as evidence that higher skilled employees move freely between informal and formal dependent employment. Informal self-employed and entrepreneurs receive large wage gains relative to their formal counterparts in the upper part of the wage distribution. Since these gains are larger than the losses in the lower half of the distribution we observe a wage premium at the mean for this group of workers. The results in table 12 also imply two tiers of jobs for informal self-employed and entrepreneurs, a lower tier of jobs that are readily available but pay substantially less than formal jobs and an upper tier of jobs that require high skills and are hard to come by but pay a lot more than formal activities.

This complex picture of informal employment in Russia is reinforced by figure 11 where we plot the coefficients from the quantile regressions for informal employees and for informal employees plus informal self-employed and entrepreneurs across the whole distribution. ${ }^{9}$ Panel a shows that informal employees are confronted with a wage penalty up to the $70^{\text {th }}$ percentile of the distribution, and from that onward there is no statistically significant difference between informal and formal wages. When we include informal self-employed and entrepreneurs the coefficients are

\footnotetext{
${ }^{9}$ There are not enough observations for informal self-employed and entrepreneurs across the whole distribution to produce a separate graph for this group.
} 
negative up to about the $60^{\text {th }}$ percentile, turning significantly positive in the upper third of the distribution. Hence, once we include informal self-employed and entrepreneurs the data display segmentation of the informal sector.

\section{Conclusions}

Using the regular waves of the Russian Longitudinal Monitoring Survey (RLMS) for the years 2003 to 2011 and a supplement on informality administered to the RLMS in 2009 we document the incidence of informal employment in the Russian labor market. The incidence varies widely according to the measure of employment used, with dependent informal employment lying between roughly 7 and 20 percent of all employees and informal self-employment having a minimum value of 45 percent and a maximum value of 73 percent of all self-employed. We also call employment informal if in the formal sector firms do only declare a part of wages to the authorities and thus do not pay all the due taxes or the social security contributions to the government. We show that this type of informal employment is wide-spread in the Russian labor market, hovering around 20 percent for dependent employees and reaching roughly 50 percent for the self-employed.

Probit regressions that use different measures of informal employment as the dependent variable establish that younger workers, males, workers with primary education or less, persons with low skills, workers in construction and trade and related services have a substantially higher likelihood of being informally employed. It is noteworthy that these drivers of informal employment dominate with nearly all definitions; only when we use firm size (5 employees or less) are the listed determinants not necessarily good predictors. For example, with the firm size definition females are more likely to be informally employed. From our probit estimates we draw two conclusions. First, the conjecture put forth by Kapeliushnikov (2012) that the determination of informal employment is not robust needs to be qualified in that our estimations show that we do have robustness with all measures apart from the firm size measure. Second, firm size does not capture informal employment well, at least in an emerging transition economy like Russia’s. 
We also have information that allows us to divide employment in either three or in five states. A dependent employee who works informally might choose to do so or might work in this state involuntarily. A self-employed worker, on the other hand, if s/he is informal is assumed to be in this state voluntarily. When we have three employment states, we group informal employment into involuntary (dependent employees) and voluntary (dependent employees and all informal selfemployed) and have formal employment (dependent employed and self-employed) as the third state. With five employment states we distinguish between dependent employees and the selfemployed. Estimating multinomial logit models we find some very robust results. The vast majority of university graduates take informal jobs out of their own volition, while immigrants from regions other than the Caucasus and Central Asia are particularly affected by involuntary employment. Finally, it is above all unskilled workers who are stuck in involuntary informal employment. When we distinguish between dependent employees and self-employed, we get some additional interesting results. While males have a higher incidence of both dependent informal employment and informal self-employment, the marginal effects of age, marital status and educational attainment have opposite signs when we distinguish between dependent and self-employment: these factors increase the likelihood to engage in informal self-employed activities, but decrease it for both voluntary and involuntary informal dependent employment. Finally, all occupations compared to unskilled workers have a higher propensity to be engaged in informal self-employment and a much lower one to be involved in dependent informal employment. We also relate risk attitudes to informal employment and show that persons who are more risk loving tend to have a higher probability to select themselves into informal employment.

Finally, we look at the issue of labor market segmentation along the informal-formal divide and within the informal sector. Our overall assessment on this first evidence would be that, on one hand, for dependent employees the Russian labor market seems to be integrated and that there are no major barriers between formal and informal employment, at least in the upper third of the skills 
distribution. On the other hand, we find a lower free entry tier of informal employment where workers encounter large wage penalties relative to their formal counterparts, and an upper rationed tier where workers earn more than the formally employed. We thus find labor market segmentation within the informal sector in Russia. 


\section{References}

Bernabè, S. and M. Stampini (2008). Labour Mobility During Transition: Evidence from Georgia. LICOS Discussion Paper Series, Discussion Paper No. 206. University of Leuven, Leuven, Belgium.

De Soto, H. (1990). The Other Path: The Invisible Revolution in the Third World. Perennial Library.

Dohmen, T., M. Khamis, and H. Lehmann (2013). Risk attitudes and the Incidence among Workers: Evidence from a Transition Country. Bonn, Middletown, CT and Bologna, mimeo.

Fields, G. (2004). A Guide to Multi-Sector Labor Market Models. School of Industrial Labor Relations Working Paper No. 86, Cornell University, Ithaca, New York.

Gimpelson, V. E. and A. A. Zudina (2011a). Informal Sector in Russia: Dynamics, Structure, Determinants (in Russian: Neformalnyj Sektor v Rossii: Dinamika, Struktura, Determinanty). In: Jasin, E. G. (Ed.). XII International Conference On Economic And Social Development, Proceedings, Book 1, Higher School of Economics, Moscow, 444458.

Gimpelson, V. E. and A. A. Zudina (2011b). Informal Workers in the Russian Economy: Who Are They and How Many? (in Russian: Neformaly v Rossijskoj Ekonomike: Skolko Ih i Kto Oni?). Higher School of Economics Working Paper WP3/2011/06, Higher School of Economics, Moscow.

Harris, J. R. and M. P. Todaro (1970). Migration, Unemployment and Development: A Two Sector Analysis. American Economic Review, 60, 126-142.

Kapeliushnikov, R. I. (2012). Informal Employment in Russia: What do the Alternative Definitions Say? (in Russian: Neformalnaja Zaniatost v Rossii: Chto Govoriat Alternativnyje Opredelenija). Higher School of Economics Working Paper WP3/2012/04.

Karabchuk, T. S. (2012). Informal Employment in Russia: Why is it so Sustainable? Economic Socilogy. The European Electronic Newsletter, 13 (2), 29-36.

Karabchuk, T.S. and M. V. Nikitina (2011). The Structure and Dynamics of Informal and Occasional Employment in Russia (in Russian: Dinamika I struktura sluchajnoj I neformalnoj zaniatosti v Rossii). Vestnik Rossijskogo Monitoringa Ekonomicheskogo Polozhenija I Zdorovja Naselenija (RLMS-HSE), Higher School of Economics, Moscow, 97-109.

Krstic, G. and P. Sanfey (2007). Mobility, Poverty and Well-Being Among the Informally Employed in Bosnia and Herzegovina. Economic Systems, 31(3), 311-335.

Lehmann, H. and K. Tatsiramos, Eds., (2012). Informal Employment in Emerging and Transition Economies. Research in Labor Economics, 34, preface, xi-xv. 
Lehmann, H., T. Razzolini and A. Zaiceva (2012) Job Separations and Informality in the Russian Labor Market. Research in Labor Economics, 34, 257-290.

Lehmann, H., A. Muravyev, T. Razzolini and A. Zaiceva (2013). The Wage and Non-wage Costs of Displacement in Boom Times: Evidence from Russia. Forthcoming 2013 in: Journal of Comparative Economics.

Lehmann, H. and A. Muravyev (2013). Labor Market Institutions and Informality in Transition and Latin American Countries. Forthcoming 2013 in: Pages, C., Rigolini, J. and D. Robalino (Eds.): Social Insurance and Labor Markets: How to Protect Workers while Creating Good Jobs, Oxford University Press.

Lehmann, H. and N. Pignatti (2007). Informal Employment and Labor Market Segmentation in Transition Economies: Evidence from Ukraine. IZA Discussion Paper No. 3269. Institute for the Study of Labor, IZA, Bonn.

Maloney, W. F. (2004). Informality Revisited. World Development, 32, 1159-1178.

Perry, G., W. Maloney, O. Arias, P. Fajnzylber, A. Mason and J. Saavedra-Chanduvi (2007). Informality: Exit and Exclusion. Washington DC: World Bank.

Slonimczyk, F. (2012). The Effect of Taxation on Informal Employment: Evidence from the Russian Flat Tax Reform. Research in Labor Economics, 34, 55—99.

Slonimczyk, F. (2013). Informality as a Stepping Stone. Higher School of Economics Working Paper WP3/2013/05, Higher School of Economics, Moscow. 


\section{TABLES}

Table 1: Employment in informal sector in the Russian Federation, 2003 and 2010 (Official Data).

\begin{tabular}{|c|c|c|c|c|c|c|c|c|}
\hline \multirow{4}{*}{$\begin{array}{l}\text { Russian Federation } \\
\text { Central region }\end{array}$} & \multicolumn{2}{|c|}{$\begin{array}{c}\text { Total individuals, } \\
\text { thous. }\end{array}$} & \multicolumn{2}{|c|}{ Main job, \% } & \multicolumn{2}{|c|}{ Additional job, \% } & \multicolumn{2}{|c|}{$\begin{array}{c}\text { Total employed in the } \\
\text { informal sector in \% } \\
\text { of total employed } \\
\text { population }\end{array}$} \\
\hline & 2010 & 2003 & 2010 & 2003 & 2010 & 2003 & 2010 & 2003 \\
\hline & 11583 & 10586,8 & 88.8 & 82.4 & 11.2 & 17.6 & 16.6 & 16.1 \\
\hline & 2443 & 2304 & 90.3 & 79 & 9.7 & 21 & 12.7 & 13.2 \\
\hline Moscow & 299 & 146.2 & 94.5 & 83.4 & 5.5 & 16.6 & 5 & 3.4 \\
\hline Norh-Western region & 618 & 897.3 & 87.9 & 85.1 & 12.1 & 14.9 & 8.7 & 12.7 \\
\hline Sankt-Petersburg & 58 & 85.8 & 85.3 & 90.6 & 14.7 & 9.4 & 2.2 & 3.6 \\
\hline Southern region & 1477 & 1851 & 88.7 & 87.7 & 11.3 & 12.3 & 23 & 22.4 \\
\hline North-Caucasus region & 1372 & - & 94.1 & - & 5.9 & - & 37.9 & - \\
\hline Volga region & 2585 & 2645.3 & 85.5 & 77.2 & 14.5 & 22.8 & 17.5 & 18.2 \\
\hline Ural region & 797 & 986.4 & 91 & 85.3 & 9 & 14.7 & 13 & 14 \\
\hline Siberia region & 1791 & 1518.8 & 86.9 & 86.4 & 13.1 & 13.6 & 19.2 & 16.8 \\
\hline Far East region & 499 & 499.9 & 88.9 & 83.8 & 11.1 & 16.2 & 15.5 & 14.4 \\
\hline
\end{tabular}

Source: Rosstat, "Social Situation and Life of the Population of Russia”, 2011 and 2004. (rus:

“Socialnoje polozhenije I uroven zhizni naselenija Rossii”). www.gks.ru

Notes: in 2003 North Caucasus was included within Southern region, thus these regions are not directly comparable across two years. 
Table 2: Incidence of informal employment: overall and by gender, education and migration status

\begin{tabular}{|c|c|c|c|}
\hline & 2003 & 2007 & 2011 \\
\hline & & Overall & \\
\hline Empl. inform., main job & 0.053 & 0.059 & 0.060 \\
\hline Empl. inform. , All & 0.089 & 0.097 & 0.094 \\
\hline Firm size $<=5$ & 0.070 & 0.070 & 0.083 \\
\hline Wage informal & n.a. & 0.180 & 0.186 \\
\hline Inform., not enterpr., main and sec. jobs & 0.141 & 0.164 & 0.168 \\
\hline \multirow[t]{2}{*}{ No three main benefits, main and sec. jobs } & 0.111 & 0.100 & 0.103 \\
\hline & & Male & \\
\hline Empl. inform., main job & 0.061 & 0.075 & 0.078 \\
\hline Empl. inform. , All & 0.095 & 0.113 & 0.112 \\
\hline Firm size $<=5$ & 0.056 & 0.048 & 0.075 \\
\hline Wage informal & n.a. & 0.207 & 0.202 \\
\hline Inform., not enterpr., main and sec. jobs & 0.155 & 0.188 & 0.199 \\
\hline \multirow{2}{*}{ No three main benefits, main and sec. jobs } & 0.120 & 0.114 & 0.129 \\
\hline & & Female & \\
\hline Empl. inform., main job & $0.047 * *$ & $0.045^{* * *}$ & $0.046^{* * *}$ \\
\hline Empl. inform. , All & 0.083 & $0.082 * * *$ & $0.077 * * *$ \\
\hline Firm size $<=5$ & 0.081 & $0.086 * * *$ & $0.090 * *$ \\
\hline Wage informal & n.a. & $0.159 * * *$ & $0.173^{* * *}$ \\
\hline Inform., not enterpr., main and sec. jobs & $0.130 * * *$ & $0.144^{* * *}$ & $0.142 * * *$ \\
\hline \multirow[t]{2}{*}{ No three main benefits, main and sec. jobs } & $0.102^{* *}$ & $0.087 * * *$ & $0.082^{* * *}$ \\
\hline & & Primary education & \\
\hline Empl. inform., main job & 0.079 & 0.098 & 0.112 \\
\hline Empl. inform. , All & 0.099 & 0.116 & 0.126 \\
\hline Firm size $<=5$ & 0.090 & 0.075 & 0.106 \\
\hline Wage informal & n.a. & 0.223 & 0.244 \\
\hline Inform., not enterpr., main and sec. jobs & 0.167 & 0.209 & 0.253 \\
\hline \multirow[t]{2}{*}{ No three main benefits, main and sec. jobs } & 0.122 & 0.103 & 0.137 \\
\hline & & Secondary education & \\
\hline Empl. inform., main job & $0.056 * *$ & $0.063 * * *$ & $0.070^{* * *}$ \\
\hline Empl. inform. , All & 0.096 & 0.104 & $0.103 * *$ \\
\hline Firm size $<=5$ & 0.079 & 0.078 & 0.095 \\
\hline Wage informal & n.a. & 0.207 & $0.204^{* *}$ \\
\hline Inform., not enterpr., main and sec. jobs & 0.151 & $0.181 * *$ & $0.186 * * *$ \\
\hline \multirow[t]{2}{*}{ No three main benefits, main and sec. jobs } & 0.111 & 0.112 & $0.113^{* *}$ \\
\hline & & Secondary education & \\
\hline Empl. inform., main job & 0.056 & 0.063 & 0.070 \\
\hline Empl. inform. , All & 0.096 & 0.104 & 0.103 \\
\hline Firm size $<=5$ & 0.079 & 0.078 & 0.095 \\
\hline Wage informal & n.a. & 0.207 & 0.204 \\
\hline Inform., not enterpr., main and sec. jobs & 0.151 & 0.181 & 0.186 \\
\hline \multirow[t]{2}{*}{ No three main benefits, main and sec. jobs } & 0.111 & 0.112 & 0.113 \\
\hline & & Higher education & \\
\hline Empl. inform., main job & $0.024 * * *$ & $0.027 * * *$ & $0.026 * * *$ \\
\hline Empl. inform. , All & $0.058 * * *$ & $0.066 * * *$ & $0.065 * * *$ \\
\hline Firm size $<=5$ & $0.036 * * *$ & $0.050 * * *$ & $0.057 * * *$ \\
\hline Wage informal & n.a. & $0.110^{* * *}$ & $0.140 * * *$ \\
\hline Inform., not enterpr., main and sec. jobs & $0.092 * * *$ & $0.096 * * *$ & $0.106 * * *$ \\
\hline \multirow[t]{2}{*}{ No three main benefits, main and sec. jobs } & 0.098 & $0.070 * * *$ & $0.073 * * *$ \\
\hline & & Immigrant from outside Russia & \\
\hline Empl. inform., main job & 0.055 & 0.071 & 0.082 \\
\hline Empl. inform. , All & 0.115 & 0.129 & 0.149 \\
\hline Firm size $<=5$ & 0.059 & 0.061 & 0.119 \\
\hline Wage informal & n.a. & 0.182 & 0.228 \\
\hline Inform., not enterpr., main and sec. jobs & 0.175 & 0.230 & 0.242 \\
\hline No three main benefits, main and sec. jobs & 0.144 & 0.120 & 0.138 \\
\hline
\end{tabular}




\begin{tabular}{lccc}
\hline \hline & & Natives \\
Empl. inform., main job & 0.053 & 0.057 & $0.059^{* *}$ \\
Empl. inform., All & $0.086^{* *}$ & $0.094^{* * *}$ & $0.089^{* * *}$ \\
Firm size $<=5$ & 0.071 & 0.070 & $0.080^{* * *}$ \\
Wage informal & n.a. & 0.180 & $0.182^{* * *}$ \\
Inform., not enterpr., main and sec. jobs & $0.138^{* *}$ & $0.158^{* * *}$ & $0.162^{* * *}$ \\
No three main benefits, main and sec. jobs & $0.107^{* *}$ & 0.097 & $0.100^{* * *}$ \\
\hline
\end{tabular}

Notes: ***,**,* denotes that difference in means for a corresponding category is significant at the 1,5 and 10 percent level. "Wage informal" is from 2009 instead of 2007; for benefits, 2010 is used instead of 2011. Immigrants refer to those born in the former USSR republics apart from Russia or in other countries. 
Table 3a: Correlation between different informality measures, 2003-2011

\begin{tabular}{|c|c|c|c|c|c|c|}
\hline & $\begin{array}{l}\text { Employed } \\
\text { informal } \\
\text { Main job }\end{array}$ & $\begin{array}{l}\text { Employee, } \\
\text { sec.job., } \\
\text { self-empl. } \\
\text { informal }\end{array}$ & $\begin{array}{l}\text { Inform., } \\
\text { not } \\
\text { enterpr., } \\
\text { main and } \\
\text { sec. jobs }\end{array}$ & $\begin{array}{l}\text { Firm size } \\
<=5\end{array}$ & $\begin{array}{l}\text { Firm size } \\
<=10\end{array}$ & $\begin{array}{l}\text { No three } \\
\text { main } \\
\text { benefits, } \\
\text { main and } \\
\text { sec. jobs }\end{array}$ \\
\hline $\begin{array}{l}\text { Empl. inf. } \\
\text { main job }\end{array}$ & 1.0000 & & & & & \\
\hline $\begin{array}{l}\text { Employee, sec.job., } \\
\text { self-empl. } \\
\text { informal }\end{array}$ & 0.9143 & 1.0000 & & & & \\
\hline $\begin{array}{l}\text { Inform., not enterpr., } \\
\text { main and sec. jobs }\end{array}$ & 0.8412 & 0.9201 & 1.0000 & & & \\
\hline Firm size $<=5$ & 0.1872 & 0.1730 & 0.1606 & 1.0000 & & \\
\hline Firm size $<=10$ & 0.2281 & 0.2112 & 0.1992 & 0.6612 & 1.0000 & \\
\hline $\begin{array}{l}\text { No three main benefits, } \\
\text { main and sec. jobs }\end{array}$ & 0.5307 & 0.5837 & 0.5380 & 0.2319 & 0.2735 & 1.0000 \\
\hline
\end{tabular}

Table 3b: Correlation between different informality measures, 2009-2011

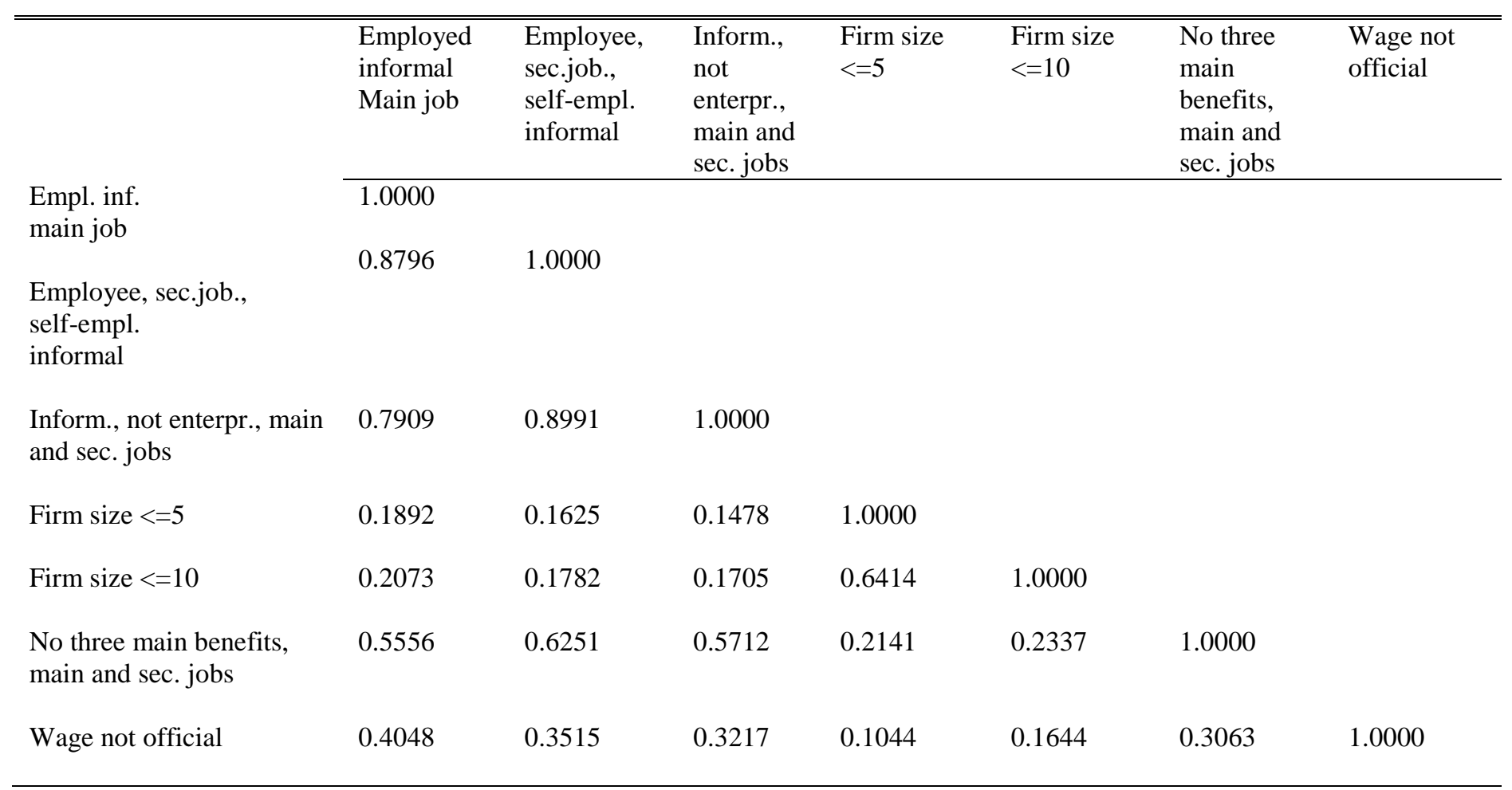


$\underline{\text { Table 4: Alternative measures of informal employment, } 2009}$

\begin{tabular}{|c|c|c|c|c|c|}
\hline \multicolumn{6}{|c|}{ Main questionnaire } \\
\hline $\begin{array}{l}\text { Employed without } \\
\text { work } \\
\text { agreement/contract, } \\
\text { main job, in \% of } \\
\text { all employees* }\end{array}$ & $\begin{array}{l}\text { Employee without } \\
\text { work agr/contract, } \\
\text { informal self- } \\
\text { employed, } \\
\text { employee without } \\
\text { agr/contract } \\
\text { second job, in \% } \\
\text { of all employed } \\
10.22\end{array}$ & $\begin{array}{l}\text { How much, you } \\
\text { think, of your } \\
\text { wage was official, } \\
\text { i.e. employer paid } \\
\text { taxes on it? (=1 if } \\
\text { part of the wage } \\
\text { was not official), } \\
\text { in \% of all } \\
\text { employees } \\
18.02\end{array}$ & $\begin{array}{l}\text { Informal self- } \\
\text { employed or works } \\
\text { not in } \\
\text { enterprise/organizat } \\
\text { ion*, in \% of all } \\
\text { self-employed } \\
\quad 73.02\end{array}$ & & \\
\hline \multicolumn{6}{|c|}{ Supplement } \\
\hline $\begin{array}{l}\text { Oral agreement } \\
\text { Employees, main } \\
\text { job } \\
\text { in \% of all } \\
\text { employees }\end{array}$ & $\begin{array}{l}\text { Oral agreement } \\
\text { employees, Not } \\
\text { regist. Business } \\
\text { self-employed, } \\
\text { oral agreement or } \\
\text { not registered } \\
\text { second job, in \% } \\
\text { of all employed } \\
\quad 14.88\end{array}$ & $\begin{array}{l}\text { Thinks/Knows } \\
\text { that employer } \\
\text { pays contributions } \\
\text { only on part of the } \\
\text { salary or doesn't } \\
\text { pay contributions } \\
\text { at all, in \% of all } \\
\text { employees } \\
19.86\end{array}$ & $\begin{array}{l}\text { Employer or own } \\
\text { firm does not pay } \\
\text { soc. security } \\
\text { contributions, in \% } \\
\text { of all employed } \\
20.44\end{array}$ & $\begin{array}{l}\text { Not register. } \\
\text { business, in } \\
\text { \% of self- } \\
\text { employed } \\
\\
44.77\end{array}$ & $\begin{array}{l}\text { You /your } \\
\text { firm does not } \\
\text { pay soc. } \\
\text { security } \\
\text { contributions, } \\
\text { in \% of all } \\
\text { self- } \\
\text { employed } \\
\quad 52.22\end{array}$ \\
\hline \multicolumn{6}{|c|}{ Additional (Supplement) } \\
\hline $\begin{array}{l}\text { Labor laws are } \\
\text { respected }<100 \% \\
\text { concerning you at } \\
\text { this job, in \% of all } \\
\text { employees } \\
\qquad 45.12\end{array}$ & $\begin{array}{l}\text { Work agreements } \\
\text { are } \\
\text { respected }<100 \% \\
\text { concerning you at } \\
\text { this job, in \% of } \\
\text { all employees } \\
\quad 40.28\end{array}$ & & & & \\
\hline
\end{tabular}

Notes: *this measure by definition includes some entrepreneurs who work in enterprise/organization.

** entrepreneurs who work in enterprise/organization and do not have a work contract/agreement or do not work in enterprise/ organization and undertake individual/entrepreneural activity. 
Table 5: Correlation between different measures of informal employment, 2009

\begin{tabular}{|c|c|c|c|c|c|c|}
\hline & $\begin{array}{l}\text { Employed } \\
\text { not } \\
\text { officially } \\
\text { registered, } \\
\text { main job }\end{array}$ & $\begin{array}{l}\text { Employee, } \\
\text { sec.job., } \\
\text { self-empl. } \\
\text { not } \\
\text { officially } \\
\text { registered }\end{array}$ & $\begin{array}{l}\text { Wage not } \\
\text { official }\end{array}$ & $\begin{array}{l}\text { Oral } \\
\text { agreement, } \\
\text { employee, } \\
\text { main job }\end{array}$ & $\begin{array}{l}\text { Oral } \\
\text { agreement } \\
\text { employees } \\
\text { main or sec. } \\
\text { job, not } \\
\text { registered } \\
\text { business }\end{array}$ & $\begin{array}{l}\text { Employer } \\
\text { doesn't pay } \\
\text { social } \\
\text { security } \\
\text { contributions }\end{array}$ \\
\hline $\begin{array}{l}\text { Employed not officially } \\
\text { registered, main job }\end{array}$ & 1.0000 & & & & & \\
\hline $\begin{array}{l}\text { Employee, sec.job., self- } \\
\text { empl. not officially } \\
\text { registered }\end{array}$ & 0.8605 & 1.0000 & & & & \\
\hline Wage not official & 0.3915 & 0.3315 & 1.0000 & & & \\
\hline $\begin{array}{l}\text { Oral agreement, employee, } \\
\text { main job }\end{array}$ & 0.9189 & 0.7902 & 0.3974 & 1.0000 & & \\
\hline $\begin{array}{l}\text { Oral agreement employees } \\
\text { main or sec. job, not } \\
\text { registered business }\end{array}$ & 0.7636 & 0.8437 & 0.3342 & 0.8330 & 1.0000 & \\
\hline $\begin{array}{l}\text { Employer doesn't pay social } \\
\text { security contributions }\end{array}$ & 0.5014 & 0.4496 & 0.6497 & 0.5087 & 0.4495 & 1.0000 \\
\hline
\end{tabular}


Table 6: Summary of the determinants of informality by different measures

\begin{tabular}{|c|c|c|c|c|c|}
\hline & $\begin{array}{c}(1) \\
\text { Informal } \\
\text { employees, main } \\
\text { job }\end{array}$ & $\begin{array}{c}(2) \\
\text { Informal } \\
\text { employees main } \\
\text { or sec. jobs, and } \\
\text { informal self- } \\
\text { employed }\end{array}$ & $\begin{array}{c}\text { (3) } \\
\text { Informal } \\
\text { employees and } \\
\text { working not in } \\
\text { enter. /org, main } \\
\text { and sec. jobs }\end{array}$ & $\begin{array}{c}\text { (4) } \\
\text { Absence of three } \\
\text { mandatory } \\
\text { benefits, main } \\
\text { and sec. jobs }\end{array}$ & $\begin{array}{c}\text { (5) } \\
\text { Firm size }<5 \\
\text { employees }\end{array}$ \\
\hline Age & $<0$ & $<0$ & $<0$ & $<0$ & $>0$ \\
\hline Male & $>0$ & $>0$ & $>0$ & $>0$ & $<0$ \\
\hline Married & $<0$ & $<0$ & $<0$ & $<0$ & n.s. \\
\hline Sec. edu. level & $<0$ & n.s. & $<0$ & n.s. & $<0$ \\
\hline High edu. level & $<0$ & $<0$ & $<0$ & $<0$ & $<0$ \\
\hline North-West & $<0$ & n.s. & $>0$ & $<0$ & n.s. \\
\hline Central-Volga & $<0$ & $<0$ & $>0$ & $<0$ & $>0$ \\
\hline South & $<0$ & n.s. & $>0$ & $<0$ & $>0$ \\
\hline East & $>0$ & $>0$ & $>0$ & $<0$ & $>0$ \\
\hline City & $<0$ & $<0$ & n.s. & $<0$ & n.s. \\
\hline Village & $<0$ & $<0$ & $<0$ & $<0$ & $>0$ \\
\hline Machine building & $<0$ & $<0$ & $<0$ & $<0$ & $<0$ \\
\hline Military & $<0$ & $<0$ & $<0$ & $<0$ & $<0$ \\
\hline Gas and oil ind. & $<0$ & $<0$ & $<0$ & $<0$ & n.s. \\
\hline Other heavy ind. & $<0$ & $<0$ & $<0$ & $<0$ & $<0$ \\
\hline Construction & $>0$ & $>0$ & $>0$ & $>0$ & $>0$ \\
\hline $\begin{array}{l}\text { Transport, } \\
\text { communication }\end{array}$ & $<0$ & n.s. & $>0$ & n.s. & $>0$ \\
\hline Agriculture & $<0$ & $<0$ & $<0$ & $<0$ & $>0$ \\
\hline $\begin{array}{l}\text { Public } \\
\text { administration }\end{array}$ & $<0$ & $<0$ & $<0$ & $<0$ & $>0$ \\
\hline Education & $<0$ & $<0$ & $<0$ & $<0$ & $<0$ \\
\hline Science and culture & $<0$ & n.s. & n.s. & n.s. & $>0$ \\
\hline Health & $<0$ & $<0$ & $<0$ & $<0$ & n.s. \\
\hline Defence & $<0$ & $<0$ & $<0$ & $<0$ & n.s. \\
\hline $\begin{array}{l}\text { Trade, related } \\
\text { services }\end{array}$ & $>0$ & $>0$ & $>0$ & $>0$ & $>0$ \\
\hline Finance & $<0$ & $<0$ & $<0$ & $<0$ & $>0$ \\
\hline
\end{tabular}




\begin{tabular}{|c|c|c|c|c|c|}
\hline Energy ind. & $\overline{c 0}$ & $\overline{c<0}$ & $2<0$ & $2<0$ & $2<0$ \\
\hline Housing & $<0$ & $<0$ & $<0$ & $<0$ & $>0$ \\
\hline Other ind. & $>0$ & $>0$ & $>0$ & $>0$ & $>0$ \\
\hline $\begin{array}{l}\text { Legislators, senior } \\
\text { managers, officials }\end{array}$ & $<0$ & $>0$ & n.s. & $<0$ & $>0$ \\
\hline Professionals & $<0$ & $<0$ & $<0$ & $<0$ & n.s. \\
\hline $\begin{array}{l}\text { Assoc. Profess. with } \\
\text { sec. spec. ed. }\end{array}$ & $<0$ & $<0$ & $<0$ & $<0$ & n.s. \\
\hline Clerks & $<0$ & $<0$ & $<0$ & $<0$ & $>0$ \\
\hline Service workers & $<0$ & $<0$ & $>0$ & n.s. & $>0$ \\
\hline $\begin{array}{l}\text { Skilled agricultural } \\
\text { and fishery workers }\end{array}$ & $<0$ & $>0$ & $>0$ & n.s. & $>0$ \\
\hline $\begin{array}{l}\text { Craft and related } \\
\text { trades }\end{array}$ & $<0$ & $<0$ & $<0$ & $<0$ & $>0$ \\
\hline $\begin{array}{l}\text { Plant/Machine } \\
\text { operators/Ind. w-s }\end{array}$ & $<0$ & $<0$ & $<0$ & $<0$ & n.s. \\
\hline Observations & 50996 & 56100 & 56100 & 42221 & 36169 \\
\hline
\end{tabular}

Notes: Signs of the marginal effects from Probit regression are reported. Specification with year, sector and occupation dummies, without immigrant dummies. Significant at the 10 percent level or better. Reference categories are: female, not married, primary education level, Moscow/St. Petersburg, large regional center, non-immigrants, year 2004, Light and food industry, Unskilled workers. The complete regressions results can be found in tables A2-A6 in the appendix. 
Table 7: Determinants of informal employment by informality status, main job, 2004-2011. Multinomial logit, Marginal effects.

\begin{tabular}{|c|c|c|c|c|c|c|c|c|c|}
\hline & $\begin{array}{l}(1) \\
\text { Involuntary } \\
\text { informal }\end{array}$ & $\begin{array}{l}(2) \\
\text { Voluntary } \\
\text { informal }\end{array}$ & $\begin{array}{l}\text { (3) } \\
\text { Formal } \\
\text { empl. }\end{array}$ & $\begin{array}{l}(4) \\
\text { Involuntary } \\
\text { informal }\end{array}$ & $\begin{array}{l}(6) \\
\text { Voluntary } \\
\text { informal }\end{array}$ & $\begin{array}{l}(6) \\
\text { Formal } \\
\text { empl. }\end{array}$ & $\begin{array}{l}\text { I) } \\
\text { Involuntary } \\
\text { informal }\end{array}$ & $\begin{array}{l}(8) \\
\text { Voluntary } \\
\text { informal }\end{array}$ & $\begin{array}{l}(9) \\
\text { Formal } \\
\text { empl. }\end{array}$ \\
\hline Age & $\begin{array}{l}-0.0002 * * * \\
(0.00003)\end{array}$ & $\begin{array}{l}-0.0002 * * * \\
(0.00003)\end{array}$ & $\begin{array}{l}0.0004 * * * \\
(0.00005)\end{array}$ & $\begin{array}{l}-0.0002^{* * *} \\
(0.00004)\end{array}$ & $\begin{array}{l}-0.0002^{* * *} \\
(0.00004)\end{array}$ & $\begin{array}{l}0.0004 * * * \\
(0.00006)\end{array}$ & $\begin{array}{l}-0.0002 * * * \\
(0.00003)\end{array}$ & $\begin{array}{l}-0.0002^{* * *} \\
(0.00003)\end{array}$ & $\begin{array}{l}0.0004 * * * \\
(0.00005)\end{array}$ \\
\hline Male & $\begin{array}{l}0.0038 * * * \\
(0.0009)\end{array}$ & $\begin{array}{l}0.0028 * * * \\
(0.0008)\end{array}$ & $\begin{array}{l}-0.0066^{* * *} \\
(0.0012)\end{array}$ & $\begin{array}{l}0.0046^{* * * *} \\
(0.0011)\end{array}$ & $\begin{array}{l}0.0029 * * * \\
(0.0009)\end{array}$ & $\begin{array}{l}-0.0075^{* * *} \\
(0.0015)\end{array}$ & $\begin{array}{l}0.0035 * * * \\
(0.0008)\end{array}$ & $\begin{array}{l}0.0031 * * * \\
(0.0008)\end{array}$ & $\begin{array}{l}-0.0067 * * * \\
(0.0011)\end{array}$ \\
\hline Married & $\begin{array}{l}-0.0047 * * * \\
(0.0009)\end{array}$ & $\begin{array}{l}-0.0027^{* * *} \\
(0.0008)\end{array}$ & $\begin{array}{l}0.0074 * * * \\
(0.0012)\end{array}$ & $\begin{array}{l}-0.0050^{* * *} \\
(0.0011)\end{array}$ & $\begin{array}{l}-0.0017^{*} \\
(0.0009)\end{array}$ & $\begin{array}{l}.0068 * * * \\
(0.0014)\end{array}$ & $\begin{array}{l}-0.0045^{* * * *} \\
(0.0008)\end{array}$ & $\begin{array}{l}-0.0029 * * * \\
(0.0008)\end{array}$ & $\begin{array}{l}0.0074 * * * \\
(0.0012)\end{array}$ \\
\hline Sec. edu. level & $\begin{array}{l}-0.0020^{* *} \\
(0.0009)\end{array}$ & $\begin{array}{l}-0.0017 * * \\
(0.0008)\end{array}$ & $\begin{array}{l}0.0037 * * * \\
(0.0012)\end{array}$ & $\begin{array}{l}-0.0020^{*} \\
(0.0011)\end{array}$ & $\begin{array}{l}-0.0011 \\
(0.0010)\end{array}$ & $\begin{array}{l}0.0031^{* *} \\
(0.0016)\end{array}$ & $\begin{array}{l}-0.0020^{* *} \\
(0.0008)\end{array}$ & $\begin{array}{l}-0.0016^{* *} \\
(0.0008)\end{array}$ & $\begin{array}{l}0.0036 * * * \\
(0.0012)\end{array}$ \\
\hline High edu. level & $\begin{array}{l}-0.0058^{* * *} \\
(0.0012)\end{array}$ & $\begin{array}{l}-0.0036^{* * *} \\
(0.0011)\end{array}$ & $\begin{array}{l}0.0094 * * * \\
(0.0017)\end{array}$ & $\begin{array}{l}-0.0071^{* * *} \\
(0.0015)\end{array}$ & $\begin{array}{l}-0.0039 * * * \\
(0.0014)\end{array}$ & $\begin{array}{l}0.0110^{* * *} \\
(0.0021)\end{array}$ & $\begin{array}{l}-0.0060^{* * * *} \\
(0.0012)\end{array}$ & $\begin{array}{l}-0.0037 * * * \\
(0.0011)\end{array}$ & $\begin{array}{l}0.0097 * * * \\
(0.0016)\end{array}$ \\
\hline North-West & $\begin{array}{l}-0.0026^{*} \\
(0.0014)\end{array}$ & $\begin{array}{l}-0.0017 \\
(0.0011)\end{array}$ & $\begin{array}{l}0.0043^{* *} \\
(0.0019)\end{array}$ & $\begin{array}{l}-0.0049 * * * \\
(0.0016)\end{array}$ & $\begin{array}{l}-0.0028^{* *} \\
(0.0013)\end{array}$ & $\begin{array}{l}0.0076^{* * *} \\
(0.0021)\end{array}$ & $\begin{array}{l}-0.0023 \\
(0.0014)\end{array}$ & $\begin{array}{l}-0.0017 \\
(0.0011)\end{array}$ & $\begin{array}{l}0.0040 * * \\
(0.0019)\end{array}$ \\
\hline Central-Volga & $\begin{array}{l}0.00004 \\
(0.0010)\end{array}$ & $\begin{array}{l}-0.0052^{* * *} \\
(0.0008)\end{array}$ & $\begin{array}{l}0.0051 * * * \\
(0.0013)\end{array}$ & $\begin{array}{l}-0.0010 \\
(0.0012)\end{array}$ & $\begin{array}{l}-0.0051^{* * *} \\
(0.0010)\end{array}$ & $\begin{array}{l}0.0061 * * * \\
(0.0016)\end{array}$ & $\begin{array}{l}0.0009 \\
(0.00010)\end{array}$ & $\begin{array}{l}-0.0048^{* * *} \\
(0.0008)\end{array}$ & $\begin{array}{l}0.0039 * * * \\
(0.0013)\end{array}$ \\
\hline South & $\begin{array}{l}-0.0006 \\
(0.0012)\end{array}$ & $\begin{array}{l}-0.0042 * * * \\
(0.0009)\end{array}$ & $\begin{array}{l}0.0048 * * * \\
(0.0016)\end{array}$ & $\begin{array}{l}0.0006 \\
(0.0016)\end{array}$ & $\begin{array}{l}-0.0042^{* * *} \\
(0.0011)\end{array}$ & $\begin{array}{l}0.0036^{*} \\
(0.0020)\end{array}$ & $\begin{array}{l}-0.0001 \\
(0.0012)\end{array}$ & $\begin{array}{l}-0.0040 * * * \\
(0.0009)\end{array}$ & $\begin{array}{l}0.0041^{* * * *} \\
(0.0015)\end{array}$ \\
\hline East & $\begin{array}{l}0.0047^{* * * *} \\
(0.0012)\end{array}$ & $\begin{array}{l}-0.0012 \\
(0.0008)\end{array}$ & $\begin{array}{l}-0.0035^{* *} \\
(0.0015)\end{array}$ & $\begin{array}{l}0.0045^{* * *} \\
(0.0015)\end{array}$ & $\begin{array}{l}-0.0017^{*} \\
(0.0010)\end{array}$ & $\begin{array}{l}-0.0028 \\
(0.0019)\end{array}$ & $\begin{array}{l}0.0053 * * * \\
(0.0012)\end{array}$ & $\begin{array}{l}-0.0012 \\
(0.0008)\end{array}$ & $\begin{array}{l}-0.0041 * * * \\
(0.0015)\end{array}$ \\
\hline City & $\begin{array}{l}-0.0020 * * * \\
(0.0008)\end{array}$ & $\begin{array}{l}-0.0032^{* * *} \\
(0.0007)\end{array}$ & $\begin{array}{l}0.0053 * * * \\
(0.0011)\end{array}$ & $\begin{array}{l}-0.0020^{* *} \\
(0.0010)\end{array}$ & $\begin{array}{l}-0.0036^{* * *} \\
(0.0008)\end{array}$ & $\begin{array}{l}0.0057 * * * \\
(0.0013)\end{array}$ & $\begin{array}{l}-0.0022^{* * * *} \\
(0.0007)\end{array}$ & $\begin{array}{l}-0.0033^{* * *} \\
(0.0007)\end{array}$ & $\begin{array}{l}0.0056^{* * * *} \\
(0.0010)\end{array}$ \\
\hline Village & $\begin{array}{l}-0.0026 * * * \\
(0.0008)\end{array}$ & $\begin{array}{l}-0.0057 * * * \\
(0.0007)\end{array}$ & $\begin{array}{l}0.0083^{* * *} \\
(0.0011)\end{array}$ & $\begin{array}{l}-0.0028^{* * *} \\
(0.0010)\end{array}$ & $\begin{array}{l}-0.0065^{* * *} \\
(0.0009)\end{array}$ & $\begin{array}{l}0.0093^{* * *} \\
(0.0014)\end{array}$ & $\begin{array}{l}-0.0028^{* * *} \\
(0.0008)\end{array}$ & $\begin{array}{l}-0.0059 * * * \\
(0.0007)\end{array}$ & $\begin{array}{l}0.0087 * * * \\
(0.0011)\end{array}$ \\
\hline Immigrant & & & & $\begin{array}{l}0.0025^{* * *} \\
(0.0009)\end{array}$ & $\begin{array}{l}0.0036^{* * *} \\
(0.0009)\end{array}$ & $\begin{array}{l}-0.0061^{* * *} \\
(0.0013)\end{array}$ & & & \\
\hline Immigrant & & & & & & & $0.0077 * * *$ & $0.0064 * * *$ & $-0.0141^{* * * *}$ \\
\hline Caucasus, CA & & & & & & & $(0.0022)$ & $(0.0021)$ & $(0.0031)$ \\
\hline Immigrant not & & & & & & & $0.0143^{* * *}$ & $0.0045^{* *}$ & $-0.0189 * * *$ \\
\hline CCA, not Russia & & & & & & & $(0.0031)$ & $(0.0023)$ & $(0.0039)$ \\
\hline Other immigrants & & & & & & & $\begin{array}{l}0.0005 \\
(0.0008)\end{array}$ & $\begin{array}{l}0.0022 * * * \\
(0.0007)\end{array}$ & $\begin{array}{l}-0.0027^{* *} \\
(0.0011)\end{array}$ \\
\hline 2005 & $\begin{array}{l}-0.00004 \\
(0.0014)\end{array}$ & $\begin{array}{l}0.0005 \\
(0.0016)\end{array}$ & $\begin{array}{l}-0.0005 \\
(0.0022)\end{array}$ & $\begin{array}{l}0.0000 \\
(0.0044)\end{array}$ & $\begin{array}{l}-0.0011 \\
(0.0043)\end{array}$ & $\begin{array}{l}0.0011 \\
(0.0064)\end{array}$ & $\begin{array}{l}0.0002 \\
(0.0014)\end{array}$ & $\begin{array}{l}0.0006 \\
(0.0016)\end{array}$ & $\begin{array}{l}-0.0009 \\
(0.0022)\end{array}$ \\
\hline 2006 & $\begin{array}{l}0.0019 \\
(0.0015)\end{array}$ & $\begin{array}{l}0.0039 * * \\
(0.0018)\end{array}$ & $\begin{array}{l}-0.0058^{* *} \\
(0.0024)\end{array}$ & $\begin{array}{l}0.0022 \\
(0.0033)\end{array}$ & $\begin{array}{l}0.0011 \\
(0.0033)\end{array}$ & $\begin{array}{l}-0.0033 \\
(0.0049)\end{array}$ & $\begin{array}{l}0.0022 \\
(0.0015)\end{array}$ & $\begin{array}{l}0.0041^{* *} \\
(0.0019)\end{array}$ & $\begin{array}{l}-0.0064 * * * \\
(0.0024)\end{array}$ \\
\hline 2007 & $-0.0026 * *$ & 0.0025 & 0.0002 & -0.0025 & 0.0014 & 0.0011 & -0.0023 & 0.0025 & -0.0002 \\
\hline
\end{tabular}




\begin{tabular}{|c|c|c|c|c|c|c|c|c|c|}
\hline & (0.0012) & (0.0017) & (0.0021) & $\begin{array}{l}(0.0031) \\
\end{array}$ & $\begin{array}{l}(0.0042) \\
\end{array}$ & $\begin{array}{l}(0.0054) \\
\end{array}$ & $\begin{array}{l}(0.0012) \\
\end{array}$ & $\begin{array}{l}(0.0017) \\
\end{array}$ & $\begin{array}{l}(0.0021) \\
\end{array}$ \\
\hline \multirow[t]{2}{*}{2008} & $-0.0036 * * *$ & 0.0022 & 0.0014 & $-0.0044 * *$ & 0.0015 & 0.0029 & $-0.0031^{* * *}$ & 0.0023 & 0.0008 \\
\hline & $(0.0012)$ & (0.0017) & (0.0021) & $(0.0021)$ & $(0.0028)$ & $(0.0037)$ & $(0.0012)$ & $(0.0017)$ & $(0.0021)$ \\
\hline \multirow[t]{2}{*}{2009} & -0.0001 & $0.0072 * * *$ & $-0.0071^{* * *}$ & -0.0011 & 0.0058 & -0.0047 & 0.0003 & $0.0074 * * *$ & $-0.0077 * * *$ \\
\hline & (0.0014) & (0.0021) & (0.0025) & $(0.0024)$ & $(0.0035)$ & $(0.0044)$ & $(0.0014)$ & $(0.0022)$ & $(0.0026)$ \\
\hline \multirow[t]{2}{*}{2010} & -0.0004 & $0.0048^{* * *}$ & $-0.0044 * *$ & -0.0013 & 0.0036 & -0.0023 & 0.0001 & $0.0049 * * *$ & $-0.0049 * *$ \\
\hline & $(0.0013)$ & $(0.0017)$ & (0 .0022) & $(0.0024)$ & $(0.0030)$ & $(0.0040)$ & $(0.0013)$ & $(0.0018)$ & $(0.0022)$ \\
\hline \multirow[t]{2}{*}{2011} & -0.0009 & $0.0050 * * *$ & $-0.0041^{*}$ & -0.0017 & 0.0039 & -0.0022 & -0.0004 & $0.0052 * * *$ & $-0.0049 * *$ \\
\hline & $(0.0013)$ & (0.0017) & $(0.0022)$ & $(0.0024)$ & $(0.0030)$ & $(0.0040)$ & $(0.0013)$ & $(0.0018)$ & $(0.0022)$ \\
\hline \multirow{2}{*}{ Machine building } & $-0.0102^{* * *}$ & $-0.0059 * * *$ & $0.0162^{* * *}$ & $-0.0103 * * *$ & $-0.0051^{* * *}$ & $0.0154^{* * *}$ & $-0.0099 * * *$ & $-0.0057 * * *$ & $0.0157^{* * *}$ \\
\hline & $(0.0010)$ & (0.0012) & (0.0016) & $(0.0012)$ & $(0.0016)$ & $(0.0021)$ & $(0.0010)$ & $(0.0012)$ & $(0.0016)$ \\
\hline \multirow[t]{2}{*}{ Military } & $-0.0134^{* * *}$ & $-0.0100 * * *$ & $0.0234 * * *$ & $-0.0132 * * *$ & $-0.0099 * * *$ & $0.0231^{* * *}$ & $-0.0129 * * *$ & $-0.0099 * * *$ & $0.0228 * * *$ \\
\hline & (0.0009) & (0.0008) & (0.0012) & $(0.0011)$ & $(0.0011)$ & $(0.0015)$ & $(0.0009)$ & $(0.0008)$ & $(0.0012)$ \\
\hline \multirow[t]{2}{*}{ Gas and oil ind. } & $-0.0123 * * *$ & $-0.0087 * * *$ & $0.0209 * * *$ & $-0.0113^{* * *}$ & $-0.0090 * * *$ & $0.0204^{* * *}$ & $-0.0119 * * *$ & $-0.0086 * * *$ & $.0205^{* * *}$ \\
\hline & $(0.0010)$ & (0.0009) & (0.0013) & $(0.0012)$ & $(0.0012)$ & $(0.0017)$ & $(0.0010)$ & $(0.0009)$ & $(0.0013)$ \\
\hline \multirow[t]{2}{*}{ Other heavy ind. } & $-0.0104^{* * *}$ & $-0.0069 * * *$ & $0.0173^{* * *}$ & $-0.0102 * * *$ & $-0.0078 * * *$ & $0.0180^{* * *}$ & $-0.0103^{* * *}$ & $-0.0067 * * *$ & $0.0170^{* * *}$ \\
\hline & $(0.0010)$ & (0.0010) & (0.0013) & $(0.0012)$ & $(0.0012)$ & $(0.0017)$ & $(0.0009)$ & $(0.0010)$ & $(0.0014)$ \\
\hline \multirow[t]{2}{*}{ Construction } & $0.0079 * * *$ & $0.0099 * * *$ & $-0.0178 * * *$ & $0.0042 * *$ & $0.0088^{* * *}$ & $-0.0130 * * *$ & $0.0071^{* * *}$ & $0.0100 * * *$ & $-0.0171^{* * *}$ \\
\hline & $(0.0019)$ & $(0.0023)$ & $(0.0030)$ & $(0.0020)$ & $(0.0027)$ & $(0.0035)$ & $(0.0018)$ & $(0.0023)$ & $(0.0030)$ \\
\hline \multirow{4}{*}{$\begin{array}{l}\text { Transport, } \\
\text { communication } \\
\text { Agriculture }\end{array}$} & $-0.0026^{* *}$ & -0.0015 & $0.0042 * *$ & $-0.0035^{* *}$ & -0.0013 & $0.0047^{* *}$ & $-0.0028 * *$ & -0.0015 & $0.0043^{* *}$ \\
\hline & $(0.0012)$ & (0.0012) & (0.0018) & $(0.0014)$ & $(0.0016)$ & $(0.0021)$ & $(0.0012)$ & $(0.0012)$ & $(0.0017)$ \\
\hline & $-0.0068 * * *$ & $-0.0051^{* * *}$ & $0.0120 * * *$ & $-0.0072 * * *$ & $-0.0049 * * *$ & $0.0122^{* * *}$ & $-0.0066^{* * *}$ & $-0.0050 * * *$ & $0.0116^{* * *}$ \\
\hline & $(0.0011)$ & (0.0012) & (0.0016) & $(0.0013)$ & $(0.0015)$ & $(0.0021)$ & $(0.0011)$ & $(0.0012)$ & $(0.0016)$ \\
\hline \multirow{4}{*}{$\begin{array}{l}\text { Public } \\
\text { administration } \\
\text { Education }\end{array}$} & $-0.0126 * * *$ & $-0.0086^{* * *}$ & $0.0212^{* * *}$ & $-0.0124 * * *$ & $-0.0089 * * *$ & $0.0213^{* * *}$ & $-0.0121 * * *$ & $-0.0084 * * *$ & $0.0205^{* * *}$ \\
\hline & $(0.0011)$ & $(0.0012)$ & (0.0016) & $(0.0013)$ & $(0.0015)$ & $(0.0020)$ & $(0.0011)$ & $(0.0012)$ & $(0.0016)$ \\
\hline & $-0.0157 * * *$ & $-0.0103^{* * *}$ & $0.0259 * * *$ & $-0.0152 * * *$ & $-0.0110^{* * *}$ & $0.0263^{* * *}$ & $-0.0154^{* * *}$ & $-0.0101^{* * *}$ & $0.0255^{* * *}$ \\
\hline & (0.0009) & (0.0009) & (0.0013) & $(0.0011)$ & $(0.0011)$ & $(0.0016)$ & $(0.0009)$ & $(0.0009)$ & $(0.0013)$ \\
\hline \multirow[t]{2}{*}{ Science and culture } & $-0.0068 * * *$ & 0.0006 & $0.0062 * *$ & $-0.0070^{* * *}$ & 0.0015 & 0.0056 & $-0.0067 * * *$ & 0.0006 & $0.0061^{* *}$ \\
\hline & $(0.0016)$ & $(0.0022)$ & (0 .0027) & (0.0018) & $(0.0028)$ & $(0.0034)$ & $(0.0015)$ & $(0.0022)$ & $(0.0027)$ \\
\hline \multirow[t]{2}{*}{ Health } & $-0.0126 * * *$ & $-0.0093^{* * *}$ & $0.0219 * * *$ & $-0.0121 * * *$ & $-0.0093^{* * *}$ & $0.0214^{* * *}$ & $-0.0121^{* * *}$ & $-0.0092 * * *$ & $0.0214^{* * *}$ \\
\hline & (0.0010) & (0.0009) & (0.0013) & $(0.0011)$ & $(0.0011)$ & $(0.0016)$ & $(0.0010)$ & $(0.0009)$ & $(0.0013)$ \\
\hline \multirow[t]{2}{*}{ Defence } & $-0.0121^{* * *}$ & $-0.0079 * * *$ & $0.0200 * * *$ & $-0.0117 * * *$ & $-0.0087 * * *$ & $0.0205^{* * *}$ & $-0.0118 * * *$ & $-0.0080 * * *$ & $0.0198 * * *$ \\
\hline & $(0.0009)$ & $(0.0009)$ & (0.0013) & $(0.0011)$ & $(0.0010)$ & $(0.0015)$ & $(0.0009)$ & $(0.0009)$ & $(0.0012)$ \\
\hline \multirow{2}{*}{$\begin{array}{l}\text { Trade, related } \\
\text { services }\end{array}$} & $0.0090 * * *$ & $0.0078^{* * *}$ & $-0.0168 * * *$ & $0.0079 * * *$ & $0.0069 * * *$ & $-0.0148 * * *$ & $0.0086 * * *$ & $0.0080 * * *$ & $-0.0166 * * *$ \\
\hline & (0.0018) & (0 .0018) & $(0.0026)$ & $(0.0021)$ & $(0.0022)$ & $(0.0031)$ & $(0.0018)$ & $(0.0019)$ & $(0.0026)$ \\
\hline \multirow[t]{2}{*}{ Finance } & $-0.0083^{* * *}$ & -0.0029 & $0.0112^{* * *}$ & $-0.0085 * * *$ & -0.0025 & $0.0109 * * *$ & $-0.0080^{* * *}$ & -0.0033 & $0.0113^{* * *}$ \\
\hline & (0.0019) & $(0.0021)$ & (0.0028) & $(0.0022)$ & $(0.0029)$ & $(0.0036)$ & $(0.0018)$ & $(0.0021)$ & $(0.0027)$ \\
\hline \multirow[t]{2}{*}{ Energy ind. } & $-0.0126 * * *$ & $-0.0081^{* * *}$ & $0.0207^{* * *}$ & $-0.0124 * * *$ & $-0.0095^{* * *}$ & $0.0219 * * *$ & $-0.0122 * * *$ & $-0.0080 * * *$ & $0.0202^{* * *}$ \\
\hline & $(0.0010)$ & (0.0011) & (0.0014) & $(0.0011)$ & $(0.0011)$ & $(0.0016)$ & $(0.0009)$ & $(0.0011)$ & $(0.0014)$ \\
\hline \multirow[t]{2}{*}{ Housing } & $-0.0112^{* * *}$ & $-0.0061 * * *$ & $0.0173^{* * *}$ & $-0.0110 * * *$ & $-0.0060 * * *$ & $0.0170^{* * *}$ & $-0.0107 * * *$ & $-0.0059 * * *$ & $0.0167 * * *$ \\
\hline & $(0.0010)$ & $(0.0011)$ & $(0.0014)$ & $(0.0011)$ & $(0.0013)$ & $(0.0018)$ & $(0.0009)$ & $(0.0011)$ & $(0.0014)$ \\
\hline
\end{tabular}




\begin{tabular}{|c|c|c|c|c|c|c|c|c|c|}
\hline Other ind. & $\begin{array}{l}.0012 \\
(0.0025)\end{array}$ & $\begin{array}{l}0.0064^{* *} \\
(0.0030)\end{array}$ & $\begin{array}{l}-0.0075^{*} \\
(0.0040)\end{array}$ & $\begin{array}{l}0.0013 \\
(0.0034)\end{array}$ & $\begin{array}{l}0.0090^{* *} \\
(0.0045)\end{array}$ & $\begin{array}{l}-0.0103^{*} \\
(0.0057)\end{array}$ & $\begin{array}{l}0.0007 \\
(0.0024)\end{array}$ & $\begin{array}{l}0.0056^{*} \\
(0.0030)\end{array}$ & $\begin{array}{l}-0.0063 \\
(0.0039)\end{array}$ \\
\hline $\begin{array}{l}\text { Legisl., senior } \\
\text { manag., officials }\end{array}$ & $\begin{array}{l}-0.0138^{* * *} \\
(0.0009)\end{array}$ & $\begin{array}{l}-0.0085^{* * *} \\
(0.0007)\end{array}$ & $\begin{array}{l}0.0223 * * * \\
(0.0011)\end{array}$ & $\begin{array}{l}-0.0138 * * * \\
(0.0010)\end{array}$ & $\begin{array}{l}-0.0091 * * * \\
(0.0009)\end{array}$ & $\begin{array}{l}0.0229 * * * \\
(0.0013)\end{array}$ & $\begin{array}{l}-0.0133 * * * \\
(0.0009)\end{array}$ & $\begin{array}{l}-0.0084 * * * \\
(0.0007)\end{array}$ & $\begin{array}{l}0.0217 * * * \\
(0.0011)\end{array}$ \\
\hline Professionals & $\begin{array}{l}-0.0159 * * * \\
(0.0011)\end{array}$ & $\begin{array}{l}-0.0121 * * * \\
(0.0009)\end{array}$ & $\begin{array}{l}0.0280 * * * \\
(0.0014)\end{array}$ & $\begin{array}{l}-0.0151 * * * \\
(0.0014)\end{array}$ & $\begin{array}{l}-0.0138^{* * *} \\
(0.0012)\end{array}$ & $\begin{array}{l}0.0289 * * * \\
(0.0018)\end{array}$ & $\begin{array}{l}-0.0153 * * * \\
(0.0011)\end{array}$ & $\begin{array}{l}-0.0119 * * * \\
(0.0009)\end{array}$ & $\begin{array}{l}0.0272 * * * \\
(0.0014)\end{array}$ \\
\hline $\begin{array}{l}\text { Assoc. Profes-s } \\
\text { with sec. spec.ed. }\end{array}$ & $\begin{array}{l}-0.0126^{* * *} \\
(0.0010)\end{array}$ & $\begin{array}{l}-0.0080 * * * \\
(0.0008)\end{array}$ & $\begin{array}{l}0.0206^{* * *} \\
(0.0013)\end{array}$ & $\begin{array}{l}-0.0125^{* * *} \\
(0.0012)\end{array}$ & $\begin{array}{l}-0.0091^{* * *} \\
(0.0010)\end{array}$ & $\begin{array}{l}0.0216 * * * \\
(0.0016)\end{array}$ & $\begin{array}{l}-0.0121^{* * *} \\
(0.0010)\end{array}$ & $\begin{array}{l}-0.0078 * * * \\
(0.0008)\end{array}$ & $\begin{array}{l}0.0199 * * * \\
(0.0013)\end{array}$ \\
\hline Clerks & $\begin{array}{l}-0.0114 * * * \\
(0.0008)\end{array}$ & $\begin{array}{l}-0.0094 * * * \\
(0.0007)\end{array}$ & $\begin{array}{l}0.0208 * * * \\
(0.0011)\end{array}$ & $\begin{array}{l}-0.0101 * * * \\
(0.0010)\end{array}$ & $\begin{array}{l}-0.0102 * * * \\
(0.0009)\end{array}$ & $\begin{array}{l}0.0204^{* * * *} \\
(0.0013)\end{array}$ & $\begin{array}{l}-0.0111^{* * *} \\
(0.0008)\end{array}$ & $\begin{array}{l}-0.0092 * * * \\
(0.0007)\end{array}$ & $\begin{array}{l}0.0203 * * * \\
(0.0011)\end{array}$ \\
\hline Service workers & $\begin{array}{l}-0.0032 * * * \\
(0.0009)\end{array}$ & $\begin{array}{l}-0.0037 * * * \\
(0.0008)\end{array}$ & $\begin{array}{l}0.0069 * * * \\
(0.0012)\end{array}$ & $\begin{array}{l}-0.0042^{* * *} \\
(0.0011)\end{array}$ & $\begin{array}{l}-0.0045^{* * * *} \\
(0.0009)\end{array}$ & $\begin{array}{l}0.0087 * * * \\
(0.0015)\end{array}$ & $\begin{array}{l}-0.0031 * * * \\
(0.0009)\end{array}$ & $\begin{array}{l}-0.0035^{* * *} \\
(0.0008)\end{array}$ & $\begin{array}{l}0.0066^{* * *} \\
(0.0013)\end{array}$ \\
\hline $\begin{array}{l}\text { Skilled agric. and } \\
\text { fishery workers }\end{array}$ & $\begin{array}{l}-0.0121 * * * \\
(0.0014)\end{array}$ & $\begin{array}{l}-0.0020 \\
(0.0041)\end{array}$ & $\begin{array}{l}0.0141 * * * \\
(0.0043)\end{array}$ & $\begin{array}{l}-0.0134 * * * \\
(0.0010)\end{array}$ & $\begin{array}{l}-0.0023 \\
(0.0057)\end{array}$ & $\begin{array}{l}0.0157 * * * \\
(0.0058)\end{array}$ & $\begin{array}{l}-0.0116^{* * *} \\
(0.0014)\end{array}$ & $\begin{array}{l}-0.0018 \\
(0.0041)\end{array}$ & $\begin{array}{l}0.0135^{* * *} \\
(0.0044)\end{array}$ \\
\hline $\begin{array}{l}\text { Craft and related } \\
\text { trades }\end{array}$ & $\begin{array}{l}-0.0043 * * * \\
(0.0009)\end{array}$ & $\begin{array}{l}-0.0039 * * * \\
(0.0007)\end{array}$ & $\begin{array}{l}0.0082 * * * \\
(0.0012)\end{array}$ & $\begin{array}{l}-0.0038 * * * \\
(0.0011)\end{array}$ & $\begin{array}{l}-0.0045^{* * * *} \\
(0.0009)\end{array}$ & $\begin{array}{l}0.0083^{* * * *} \\
(0.0015)\end{array}$ & $\begin{array}{l}-0.0041 * * * \\
(0.0008)\end{array}$ & $\begin{array}{l}-0.0039 * * * \\
(0.0007)\end{array}$ & $\begin{array}{l}0.0080^{* * * *} \\
(0.0011)\end{array}$ \\
\hline $\begin{array}{l}\text { Plant and Machine } \\
\text { operators/Ind. w-s. } \\
\text { Observations }\end{array}$ & $\begin{array}{l}-0.0081^{* * *} \\
(0.0008) \\
50732\end{array}$ & $\begin{array}{l}-0.0064^{* * *} \\
(0.0007)\end{array}$ & $\begin{array}{l}0.0145^{* * *} \\
(0.0011)\end{array}$ & $\begin{array}{l}-0.0070 * * * \\
(0.0010) \\
31871\end{array}$ & $\begin{array}{l}-0.0076^{* * *} \\
(0.0009)\end{array}$ & $\begin{array}{l}0.0147 * * * \\
(0.0014)\end{array}$ & $\begin{array}{l}-0.0077^{* * *} \\
(0.0008) \\
50177\end{array}$ & $\begin{array}{l}-0.0062 * * * \\
(0.0007)\end{array}$ & $\begin{array}{l}0.0140 * * * \\
(0.0011)\end{array}$ \\
\hline
\end{tabular}

Notes: Robust standard errors in parentheses. ${ }^{* * *} \mathrm{p}<0.01,{ }^{* *} \mathrm{p}<0.05,{ }^{*} \mathrm{p}<0.1$ Reference categories: female, not married, primary education level, Moscow/St. Petersburg,

large regional center, non-immigrants, year 2004, light and food industry, unskilled workers. 
Table 8: Determinants of informal employment by informality status, main job and self-employment, 2004-2011. Multinomial logit, Marginal effects.

\begin{tabular}{|c|c|c|c|c|c|}
\hline & $\begin{array}{c}(1) \\
\text { Involuntary } \\
\text { informal } \\
\text { employee }\end{array}$ & \begin{tabular}{c}
\multicolumn{1}{c}{$(2)$} \\
Voluntary \\
informal \\
employee
\end{tabular} & $\begin{array}{c}(3) \\
\text { Informal } \\
\text { self- } \\
\text { employed }\end{array}$ & $\begin{array}{c}\text { (4) } \\
\text { Formal self- } \\
\text { employed }\end{array}$ & $\begin{array}{c}\text { (5) } \\
\text { Formal } \\
\text { employee }\end{array}$ \\
\hline Age & $\begin{array}{c}-0.0002^{* * *} \\
(.00004)\end{array}$ & $\begin{array}{c}-0.0001^{* * *} \\
(0.00002)\end{array}$ & $\begin{array}{c}0.0001^{* * *} \\
(0.00001)\end{array}$ & $\begin{array}{c}0.00001 \\
(0.00001)\end{array}$ & $\begin{array}{l}0.0003^{* * *} \\
(0.00005)\end{array}$ \\
\hline Male & $\begin{array}{c}0.0031^{* * *} \\
(0.0008)\end{array}$ & $\begin{array}{c}0.0019 * * * \\
(0.0006)\end{array}$ & $\begin{array}{c}0.0027 * * * \\
(0.0004)\end{array}$ & $\begin{array}{c}0.0012^{* * *} \\
(0.0002)\end{array}$ & $\begin{array}{c}-0.0088^{* * *} \\
(0.0012)\end{array}$ \\
\hline Married & $\begin{array}{c}-0.0042^{* * *} \\
(0.0009)\end{array}$ & $\begin{array}{c}-0.0021^{* * * *} \\
(0.0006)\end{array}$ & $\begin{array}{c}0.0015 * * * \\
(0.0003)\end{array}$ & $\begin{array}{c}0.0007 * * * \\
(0.0002)\end{array}$ & $\begin{array}{c}0.0041^{* * *} \\
(0.0011)\end{array}$ \\
\hline Sec. edu. level & $\begin{array}{l}-0.0018^{* *} \\
(0.0009)\end{array}$ & $\begin{array}{l}-0.0012^{*} \\
(0.0006)\end{array}$ & $\begin{array}{c}0.0011 * * * \\
(0.0004)\end{array}$ & $\begin{array}{l}0.0007 * * \\
(0.0003)\end{array}$ & $\begin{array}{c}0.0011 \\
(0.0012)\end{array}$ \\
\hline High edu. level & $\begin{array}{c}-0.0061^{* * *} \\
(0.0013)\end{array}$ & $\begin{array}{c}-0.0026 * * * \\
(0.0008)\end{array}$ & $\begin{array}{l}0.0010^{*} \\
(0.0006)\end{array}$ & $\begin{array}{l}0.0012^{* *} \\
(0.0005)\end{array}$ & $\begin{array}{c}0.0064 * * * \\
(0.0017)\end{array}$ \\
\hline North-West & $\begin{array}{c}-0.0035^{* *} \\
(0.0014)\end{array}$ & $\begin{array}{c}-0.0020 * * \\
(0.0008)\end{array}$ & $\begin{array}{l}0.0021^{* *} \\
(0.0009)\end{array}$ & $\begin{array}{l}-0.00004 \\
(0.0003)\end{array}$ & $\begin{array}{l}0.0035^{*} \\
(0.0020)\end{array}$ \\
\hline Central-Volga & $\begin{array}{c}-0.0008 \\
(0.0010)\end{array}$ & $\begin{array}{c}-0.0045^{* * *} \\
(0.0006)\end{array}$ & $\begin{array}{c}0.0024 * * * \\
(0.0005)\end{array}$ & $\begin{array}{l}0.0004^{*} \\
(0.0002)\end{array}$ & $\begin{array}{l}0.0025^{*} \\
(0.0014)\end{array}$ \\
\hline South & $\begin{array}{l}-0.0020^{*} \\
(0.0012)\end{array}$ & $\begin{array}{c}-0.0038^{* * *} \\
(0.0006)\end{array}$ & $\begin{array}{c}0.0044 * * * \\
(0.0009)\end{array}$ & $\begin{array}{l}0.00005 \\
(0.0003)\end{array}$ & $\begin{array}{c}0.0014 \\
(0.0017)\end{array}$ \\
\hline East & $\begin{array}{c}0.0037 * * * \\
(0.0012)\end{array}$ & $\begin{array}{c}-0.0017 * * * \\
(0.0006)\end{array}$ & $\begin{array}{c}0.0022 * * * \\
(0.0006)\end{array}$ & $\begin{array}{l}0.00003 \\
(0.0002)\end{array}$ & $\begin{array}{c}-0.0042 * * * \\
(0.0016)\end{array}$ \\
\hline City & $\begin{array}{c}-0.0032^{* * *} \\
(0.0008)\end{array}$ & $\begin{array}{c}-0.0030 * * * \\
(0.0005)\end{array}$ & $\begin{array}{c}0.0025 * * * \\
(0.0004)\end{array}$ & $\begin{array}{l}-0.00004 \\
(0.0002)\end{array}$ & $\begin{array}{c}0.0037^{* * *} \\
(0.0011)\end{array}$ \\
\hline Village & $\begin{array}{c}-0.0044^{* * *} \\
(0.0008)\end{array}$ & $\begin{array}{c}-0.0049 * * * \\
(0.0006)\end{array}$ & $\begin{array}{c}-0.0001 \\
(0.0004)\end{array}$ & $\begin{array}{l}-0.0001 \\
(0.0002)\end{array}$ & $\begin{array}{c}0.0096^{* * *} \\
(0.0011)\end{array}$ \\
\hline Immigrant & $0.0059 * * *$ & $0.0032 * *$ & $0.0089 * * *$ & $0.0013^{* * *}$ & $-0.0193 * * *$ \\
\hline Caucasus, CA & $(0.0021)$ & $(0.0015)$ & (0.0013) & (0 .0005) & (0.0030) \\
\hline Immigrant not & $0.0134 * * *$ & $0.0029 *$ & 0.0013 & 0.0003 & $-0.0179 * * *$ \\
\hline CCA, not Russia & $(0.0030)$ & $(0.0017)$ & (0.0009) & $(0.0004)$ & (0 .0037) \\
\hline Other immigrants & $\begin{array}{c}0.0006 \\
(0.0008)\end{array}$ & $\begin{array}{c}0.0017 * * * \\
(0.0006)\end{array}$ & $\begin{array}{c}-0.0001 \\
(0.0003)\end{array}$ & $\begin{array}{c}-0.0002 \\
(0.0002)\end{array}$ & $\begin{array}{l}-0.0021^{*} \\
(0.0011)\end{array}$ \\
\hline 2005 & $\begin{array}{c}0.0006 \\
(0.0015)\end{array}$ & $\begin{array}{c}0.0010 \\
(0.0013)\end{array}$ & $\begin{array}{l}-0.0005 \\
(0.0006)\end{array}$ & $\begin{array}{l}0.0010^{*} \\
(0.0006)\end{array}$ & $\begin{array}{c}-0.0021 \\
(0.0022)\end{array}$ \\
\hline 2006 & $\begin{array}{c}0.0025 \\
(0.0016)\end{array}$ & $\begin{array}{l}0.0034^{* *} \\
(0.0015)\end{array}$ & $\begin{array}{c}-0.0003 \\
(0.0006)\end{array}$ & $\begin{array}{l}0.0008 * \\
(0.0005)\end{array}$ & $\begin{array}{c}-0.0063^{* * *} \\
(0.0024)\end{array}$ \\
\hline 2007 & $-0.0025 *$ & $0.0023 *$ & -0.0006 & $-0.0021 * * *$ & 0.0030 \\
\hline
\end{tabular}




\begin{tabular}{|c|c|c|c|c|c|}
\hline & (0.0013) & (0.0014) & (0.0005) & (0.0003) & (0.0020) \\
\hline \multirow[t]{2}{*}{2008} & $-0.0031 * *$ & 0.0022 & 0.0008 & 0.0005 & -0.0004 \\
\hline & (0 .0013) & (0.0014) & (0.0006) & (0.0004) & (0.0021) \\
\hline \multirow[t]{2}{*}{2009} & 0.0003 & $0.0059 * * *$ & 0.0003 & $0.0013^{* *}$ & $-0.0078^{* * *}$ \\
\hline & $(0.0015)$ & $(0.0017)$ & $(0.0006)$ & $(0.0006)$ & $(0.0025)$ \\
\hline \multirow[t]{2}{*}{2010} & 0.0001 & $0.0038 * * *$ & 0.0007 & $0.0027 * * *$ & $-0.0073^{* * *}$ \\
\hline & (0.0014) & $(0.0014)$ & $(0.0006)$ & (0.0008) & $(0.0022)$ \\
\hline \multirow[t]{2}{*}{2011} & -0.0006 & $0.0042^{* * *}$ & 0.0006 & $0.0024 * * *$ & $-0.0066^{* * *}$ \\
\hline & (0.0013) & (0 .0014) & (0.0006) & (0 .0007) & (0.0022) \\
\hline \multirow[t]{2}{*}{ Machine building } & $-0.0105^{* * *}$ & $-0.0042 * * *$ & $-0.0051^{* * *}$ & $-0.0013^{* * *}$ & $0.0211^{* * *}$ \\
\hline & (0 .0011) & $(0.0010)$ & (0 .0005) & (0 .0003) & $(0.0015)$ \\
\hline \multirow[t]{2}{*}{ Military } & $-0.0141^{* * *}$ & $-0.0102 * * *$ & $-0.0046^{* * *}$ & $-0.0012 * * *$ & $0.0302^{* * *}$ \\
\hline & (0 .0008) & $(0.0006)$ & $(0.0006)$ & $(0.0003)$ & (0.0012) \\
\hline \multirow[t]{2}{*}{ Gas and oil ind. } & $-0.0125 * * *$ & $-0.0064 * * *$ & $-0.0080 * * *$ & -0.0005 & $0.0274 * * *$ \\
\hline & $(0.0010)$ & $(0.0007)$ & $(0.0006)$ & $(0.0004)$ & $(0.0014)$ \\
\hline \multirow[t]{2}{*}{ Other heavy ind. } & $-0.0108 * * *$ & $-0.0050 * * *$ & $-0.0053^{* * *}$ & $-0.0012 * * *$ & $0.0223^{* * *}$ \\
\hline & $(0.0010)$ & $(0.0008)$ & $(0.0004)$ & $(0.0003)$ & $(0.0013)$ \\
\hline \multirow[t]{2}{*}{ Construction } & $0.0044 * * *$ & $0.0053 * * *$ & $0.0084^{* * *}$ & $0.0008 *$ & $-0.0189 * * *$ \\
\hline & $(0.0017)$ & $(0.0015)$ & $(0.0020)$ & $(0.0005)$ & $(0.0031)$ \\
\hline \multirow{4}{*}{$\begin{array}{l}\text { Transport, } \\
\text { communication } \\
\text { Agriculture }\end{array}$} & $-0.0035^{* * *}$ & $-0.0017^{*}$ & $0.0068 * * *$ & -0.0002 & -0.0014 \\
\hline & (0.0012) & (0 .0009) & (0.0018) & (0.0003) & (0.0024) \\
\hline & $-0.0067 * * *$ & $-0.0037 * * *$ & 0.0015 & $-0.0007 * *$ & $0.0096^{* * *}$ \\
\hline & (0 .0012) & (0 .0009) & $(0.0012)$ & (0 .0003) & (0 .0020) \\
\hline \multirow{2}{*}{$\begin{array}{l}\text { Public } \\
\text { administration }\end{array}$} & $-0.0128 * * *$ & $-0.0069 * * *$ & $-0.0043 * * *$ & $-0.0016^{* * *}$ & $0.0257^{* * *}$ \\
\hline & (0 .0012) & $(0.0008)$ & $(0.0006)$ & $(0.0002)$ & $(0.0015)$ \\
\hline \multirow[t]{2}{*}{ Education } & $-0.0160 * * *$ & $-0.0076 * * *$ & $-0.0027 * * *$ & $-0.0021^{* * *}$ & $0.0283^{* * *}$ \\
\hline & (0 .0009) & (0 .0007) & (0 .0007) & $(0.0003)$ & (0 .0014) \\
\hline \multirow[t]{2}{*}{ Science and culture } & $-0.0073 * * *$ & 0.0004 & -0.0007 & $-0.0008 * * *$ & $0.0083^{* * *}$ \\
\hline & $(0.0016)$ & $(0.0017)$ & (0.0013) & $(0.0003)$ & $(0.0027)$ \\
\hline \multirow[t]{2}{*}{ Health } & $-0.0126 * * *$ & $-0.0069 * * *$ & $-0.0028 * * *$ & -0.0005 & $0.0227^{* * *}$ \\
\hline & $(0.0010)$ & $(0.0007)$ & (0.0008) & $(0.0004)$ & $(0.0015)$ \\
\hline \multirow[t]{2}{*}{ Defence } & $-0.0122 * * *$ & $-0.0059 * * *$ & $-0.0040 * * *$ & $-0.0013^{* * *}$ & $0.0234^{* * *}$ \\
\hline & $(0.0010)$ & $(0.0007)$ & $(0.0006)$ & $(0.0002)$ & $(0.0013)$ \\
\hline \multirow{2}{*}{$\begin{array}{l}\text { Trade, related } \\
\text { services }\end{array}$} & $0.0062 * * *$ & $0.0047 * * *$ & $0.0210^{* * *}$ & $0.0023^{* * *}$ & $-0.0342 * * *$ \\
\hline & (0 .0016) & (0 .0013) & $(0.0031)$ & (0 .0007) & (0 .0038) \\
\hline \multirow[t]{2}{*}{ Finance } & $-0.0088 * * *$ & $-0.0027^{*}$ & -0.0010 & $-0.0011^{* * *}$ & $0.0135^{* * *}$ \\
\hline & (0 .0018) & $(0.0015)$ & $(0.0015)$ & (0.0003) & (0 .0029) \\
\hline \multirow[t]{2}{*}{ Energy ind. } & $-0.0128 * * *$ & $-0.0060 * * *$ & $-0.0050 * * *$ & $-0.0015^{* * *}$ & $0.0253^{* * *}$ \\
\hline & $(0.0010)$ & $(0.0008)$ & $(0.0004)$ & $(0.0002)$ & $(0.0014)$ \\
\hline \multirow[t]{2}{*}{ Housing } & $-0.0113^{* * *}$ & $-0.0046 * * *$ & $-0.0028 * * *$ & $-0.0011^{* * *}$ & 0.0199 *** \\
\hline & $(0.0010)$ & $(0.0008)$ & (0.0007) & $(0.0003)$ & $(0.0015)$ \\
\hline
\end{tabular}




\begin{tabular}{lccccc}
\hline Other ind. & -0.0028 & 0.0012 & $0.0224^{* * *}$ & $0.0019^{*}$ & $-0.0226^{* * *}$ \\
& $(0.0019)$ & $(0.0017)$ & $(0.0051)$ & $(0.0010)$ & $(0.0059)$ \\
Legisl., senior & $-0.0143^{* * *}$ & $-0.0073^{* * *}$ & $0.1094^{* * *}$ & $0.2387^{* * *}$ & $-.3266^{* * *}$ \\
manag., officials & $(0.0009)$ & $(0.0005)$ & $(0.0218)$ & $(0.0924)$ & $(0.0796)$ \\
Professionals & $-0.0154^{* * *}$ & $-0.0088^{* * *}$ & $0.0094^{* * *}$ & $0.0150^{* *}$ & -0.0001 \\
& $(0.0011)$ & $(0.0006)$ & $(0.0026)$ & $(0.0074)$ & $(0.0078)$ \\
Assoc. Profes-s & $-0.0122^{* * *}$ & $-0.0057^{* * *}$ & $0.0042^{* *}$ & $0.0070^{*}$ & 0.0067 \\
with sec. spec.ed. & $(0.0010)$ & $(0.0006)$ & $(0.0016)$ & $(0.0039)$ & $(0.0043)$ \\
Clerks & $-0.0113^{* * *}$ & $-0.0068^{* * *}$ & $-0.0037^{* * *}$ & 0.0014 & $0.0205^{* * *}$ \\
& $(0.0009)$ & $(0.0005)$ & $(0.0009)$ & $(0.0023)$ & $(0.0026)$ \\
Service workers & $-0.0047^{* * *}$ & $-0.0035^{* * *}$ & $0.0241^{* * *}$ & $0.0186^{* *}$ & $-0.0344^{* * *}$ \\
& $(0.0009)$ & $(0.0006)$ & $(0.0044)$ & $(0.0092)$ & $(0.0099)$ \\
Skilled agric. and & $-0.0127^{* * *}$ & -0.0029 & $0.2187^{* * *}$ & $0.1154^{*}$ & $-.3185^{* * *}$ \\
fishery workers & $(0.0013)$ & $(0.0024)$ & $(0.0483)$ & $(0.0649)$ & $(0.0651)$ \\
Craft and related & $-0.0046^{* * *}$ & $-0.0032^{* * *}$ & $0.0256^{* * *}$ & $0.0109 *$ & $-0.0287^{* * *}$ \\
trades & $(0.0009)$ & $(0.0005)$ & $(0.0046)$ & $(0.0058)$ & $(0.0072)$ \\
Plant and Machine & $-0.0078^{* * *}$ & $-0.0044^{* * *}$ & $0.0123^{* * *}$ & 0.0039 & -0.0040 \\
operators/Ind. w-s. & $(0.0009)$ & $(0.0005)$ & $(0.0026)$ & $(0.0026)$ & $(0.0038)$ \\
Observations & & 55232 & & &
\end{tabular}

Notes: Robust standard errors in parentheses. ${ }^{* * *} \mathrm{p}<0.01,{ }^{* *} \mathrm{p}<0.05,{ }^{*} \mathrm{p}<0.1$ Reference categories: female, not married, primary education level, Moscow/St. Petersburg,

large regional center, non-immigrants, year 2004, light and food industry, unskilled workers. 
Table 9: Risk Measures and Informal Employment, Main job, 2009: Probit Regressions, Marginal Effects

\begin{tabular}{|c|c|c|c|c|c|c|c|c|}
\hline & $\begin{array}{c}\text { (1) } \\
\text { Emplinform, } \\
\text { Probit }\end{array}$ & $\begin{array}{c}(2) \\
\text { Emplinform, } \\
\text { Probit }\end{array}$ & $\begin{array}{c}(3) \\
\text { Emplinform, } \\
\text { Probit }\end{array}$ & $\begin{array}{c}\text { (4) } \\
\text { Emplinform, } \\
\text { Probit }\end{array}$ & $\begin{array}{c}(5) \\
\text { Emplinform, } \\
\text { Probit }\end{array}$ & $\begin{array}{c}(6) \\
\text { Emplinform, } \\
\text { Probit }\end{array}$ & $\begin{array}{c}(7) \\
\text { Emplinform, } \\
\text { Probit }\end{array}$ & $\begin{array}{c}\text { (8) } \\
\text { Emplinform, } \\
\text { Probit }\end{array}$ \\
\hline Risk Attitudes & $\begin{array}{c}0.002 * * * \\
(0.001)\end{array}$ & $\begin{array}{c}0.002 * * * \\
(0.001)\end{array}$ & & & & & & \\
\hline Risk indicator & & & $\begin{array}{c}0.015^{* * *} \\
(0.006)\end{array}$ & $\begin{array}{c}0.013 * * \\
(0.005)\end{array}$ & & & & \\
\hline Risk fin. & & & & & $\begin{array}{c}0.002^{* * *} \\
(0.001)\end{array}$ & $\begin{array}{c}0.002^{* * *} \\
(0.001)\end{array}$ & & \\
\hline Risk indic. Fin. & & & & & & & $\begin{array}{c}0.023^{* * *} \\
(0.008)\end{array}$ & $\begin{array}{c}0.022 * * * \\
(0.008)\end{array}$ \\
\hline Age & $\begin{array}{c}-0.000 * * \\
(0.000)\end{array}$ & $\begin{array}{c}-0.001 * * * \\
(0.000)\end{array}$ & $\begin{array}{c}-0.000 * * \\
(0.000)\end{array}$ & $\begin{array}{c}-0.001 * * * \\
(0.000)\end{array}$ & $\begin{array}{c}-0.000 * * \\
(0.000)\end{array}$ & $\begin{array}{c}-0.001^{* * * *} \\
(0.000)\end{array}$ & $\begin{array}{c}-0.000^{* *} \\
(0.000)\end{array}$ & $\begin{array}{c}-0.001 * * * \\
(0.000)\end{array}$ \\
\hline Male & $\begin{array}{c}0.013 * * \\
(0.005)\end{array}$ & $\begin{array}{c}0.013 * * \\
(0.005)\end{array}$ & $\begin{array}{c}0.014 * * \\
(0.005)\end{array}$ & $\begin{array}{c}0.014 * * * \\
(0.005)\end{array}$ & $\begin{array}{c}0.014^{* *} \\
(0.005)\end{array}$ & $\begin{array}{c}0.014^{* *} \\
(0.005)\end{array}$ & $\begin{array}{c}0.014 * * * \\
(0.005)\end{array}$ & $\begin{array}{c}0.014 * * * \\
(0.005)\end{array}$ \\
\hline Married & $\begin{array}{c}-0.008 \\
(0.005)\end{array}$ & $\begin{array}{c}-0.009 * \\
(0.005)\end{array}$ & $\begin{array}{c}-0.008 \\
(0.005)\end{array}$ & $\begin{array}{l}-0.009^{*} \\
(0.005)\end{array}$ & $\begin{array}{l}-0.007 \\
(0.005)\end{array}$ & $\begin{array}{l}-0.007 \\
(0.005)\end{array}$ & $\begin{array}{l}-0.006 \\
(0.005)\end{array}$ & $\begin{array}{l}-0.007 \\
(0.005)\end{array}$ \\
\hline Sec. edu. & $\begin{array}{c}-0.007 \\
(0.006)\end{array}$ & $\begin{array}{c}-0.006 \\
(0.006)\end{array}$ & $\begin{array}{c}-0.006 \\
(0.006)\end{array}$ & $\begin{array}{c}-0.006 \\
(0.006)\end{array}$ & $\begin{array}{c}-0.008 \\
(0.006)\end{array}$ & $\begin{array}{c}-0.007 \\
(0.006)\end{array}$ & $\begin{array}{l}-0.007 \\
(0.006)\end{array}$ & $\begin{array}{c}-0.007 \\
(0.006)\end{array}$ \\
\hline High edu. & $\begin{array}{c}-0.018 * * \\
(0.008)\end{array}$ & $\begin{array}{c}-0.017 * * \\
(0.008)\end{array}$ & $\begin{array}{c}-0.018 * * \\
(0.008)\end{array}$ & $\begin{array}{c}-0.017 * * \\
(0.008)\end{array}$ & $\begin{array}{c}-0.020 * * * \\
(0.007)\end{array}$ & $\begin{array}{c}-0.019 * * \\
(0.007)\end{array}$ & $\begin{array}{c}-0.019 * * * \\
(0.007)\end{array}$ & $\begin{array}{c}-0.019 * * \\
(0.007)\end{array}$ \\
\hline City & $\begin{array}{c}-0.010^{* *} \\
(0.005)\end{array}$ & $\begin{array}{c}-0.011^{* *} \\
(0.005)\end{array}$ & $\begin{array}{c}-0.010^{* *} \\
(0.005)\end{array}$ & $\begin{array}{c}-0.011^{* *} \\
(0.005)\end{array}$ & $\begin{array}{c}-0.010^{* *} \\
(0.005)\end{array}$ & $\begin{array}{c}-0.011^{* *} \\
(0.005)\end{array}$ & $\begin{array}{c}-0.010^{* *} \\
(0.005)\end{array}$ & $\begin{array}{c}-0.011^{* *} \\
(0.005)\end{array}$ \\
\hline Village & $\begin{array}{c}-0.015^{* * *} \\
(0.005)\end{array}$ & $\begin{array}{c}-0.016^{* * *} \\
(0.005)\end{array}$ & $\begin{array}{c}-0.015^{* * *} \\
(0.005)\end{array}$ & $\begin{array}{c}-0.016^{* * *} \\
(0.005)\end{array}$ & $\begin{array}{c}-0.015^{* * * *} \\
(0.005)\end{array}$ & $\begin{array}{c}-0.016^{* * *} \\
(0.005)\end{array}$ & $\begin{array}{c}-0.015 * * * \\
(0.005)\end{array}$ & $\begin{array}{c}-0.016^{* * *} \\
(0.005)\end{array}$ \\
\hline Ln hh. income & $\begin{array}{c}-0.009 * * \\
(0.004)\end{array}$ & $\begin{array}{c}-0.009 * * \\
(0.004)\end{array}$ & $\begin{array}{c}-0.009 * * \\
(0.004)\end{array}$ & $\begin{array}{c}-0.009 * * \\
(0.004)\end{array}$ & $\begin{array}{c}-0.009 * * \\
(0.004)\end{array}$ & $\begin{array}{c}-0.009 * * \\
(0.004)\end{array}$ & $\begin{array}{c}-0.009 * * \\
(0.004)\end{array}$ & $\begin{array}{c}-0.009 * * \\
(0.004)\end{array}$ \\
\hline $\begin{array}{l}\text { Immigr. Not CCA, } \\
\text { not Russia }\end{array}$ & & $\begin{array}{l}0.035^{*} \\
(0.019)\end{array}$ & & $\begin{array}{l}0.035^{*} \\
(0.019)\end{array}$ & & $\begin{array}{l}0.038 * * \\
(0.019)\end{array}$ & & $\begin{array}{l}0.039 * * \\
(0.019)\end{array}$ \\
\hline Immigr. Caucasus, CA & & $\begin{array}{c}0.019 \\
(0.014)\end{array}$ & & $\begin{array}{c}0.019 \\
(0.014)\end{array}$ & & $\begin{array}{c}0.023 \\
(0.014)\end{array}$ & & $\begin{array}{c}0.023 \\
(0.014)\end{array}$ \\
\hline Immigr. other & & $\begin{array}{l}0.010^{* *} \\
(0.005)\end{array}$ & & $\begin{array}{l}0.010^{* *} \\
(0.005)\end{array}$ & & $\begin{array}{l}0.010^{*} \\
(0.005)\end{array}$ & & $\begin{array}{l}0.010^{*} \\
(0.005)\end{array}$ \\
\hline Observations & 5272 & 5234 & 5272 & 5234 & 5281 & 5244 & 5281 & 5244 \\
\hline
\end{tabular}


Table 10: Hourly wage gap: Informal employees. Based on wage in the last 30 days, main job

\begin{tabular}{|c|c|c|c|c|c|c|}
\hline & (1) & $\begin{array}{l}(2) \\
\text { OLS }\end{array}$ & (3) & (4) & $\begin{array}{l}\text { (5) } \\
\mathrm{FE}\end{array}$ & (6) \\
\hline Informal employee & $\begin{array}{c}-0.095 * * * \\
(0.013)\end{array}$ & $\begin{array}{c}-0.122 * * * \\
(0.013)\end{array}$ & $\begin{array}{c}-0.075 * * * \\
(0.013)\end{array}$ & $\begin{array}{l}-0.013 \\
(0.018)\end{array}$ & $\begin{array}{l}-0.028 \\
(0.019)\end{array}$ & $\begin{array}{l}-0.023 \\
(0.019)\end{array}$ \\
\hline Age & $\begin{array}{c}0.033 * * * \\
(0.002)\end{array}$ & $\begin{array}{c}0.032 * * * \\
(0.002)\end{array}$ & $\begin{array}{c}0.030^{* * *} \\
(0.002)\end{array}$ & $\begin{array}{c}0.066^{* * *} \\
(0.013)\end{array}$ & $\begin{array}{c}0.068 * * * \\
(0.013)\end{array}$ & $\begin{array}{c}0.064 * * * \\
(0.013)\end{array}$ \\
\hline Age squared & $\begin{array}{c}-0.000^{* * * *} \\
(0.000)\end{array}$ & $\begin{array}{c}-0.000^{* * * *} \\
(0.000)\end{array}$ & $\begin{array}{c}-0.000 * * * \\
(0.000)\end{array}$ & $\begin{array}{c}-0.001^{* * *} \\
(0.000)\end{array}$ & $\begin{array}{c}-0.001^{* * *} \\
(0.000)\end{array}$ & $\begin{array}{c}-0.001^{* * *} \\
(0.000)\end{array}$ \\
\hline Male & $\begin{array}{c}0.301 * * * \\
(0.006)\end{array}$ & $\begin{array}{c}0.231 * * * \\
(0.007)\end{array}$ & $\begin{array}{c}0.212^{* * *} \\
(0.007)\end{array}$ & & & \\
\hline Married & $\begin{array}{c}0.057 * * * \\
(0.007)\end{array}$ & $\begin{array}{c}0.056^{* * *} \\
(0.007)\end{array}$ & $\begin{array}{c}0.050^{* * *} \\
(0.007)\end{array}$ & $\begin{array}{l}0.025^{*} \\
(0.014)\end{array}$ & $\begin{array}{c}0.023 \\
(0.014)\end{array}$ & $\begin{array}{l}0.025^{*} \\
(0.014)\end{array}$ \\
\hline Sec. edu. & $\begin{array}{c}0.141^{* * *} \\
(0.009)\end{array}$ & $\begin{array}{c}0.128 * * * \\
(0.009)\end{array}$ & $\begin{array}{c}0.085^{* * *} \\
(0.009)\end{array}$ & $\begin{array}{c}0.014 \\
(0.023)\end{array}$ & $\begin{array}{c}0.021 \\
(0.023)\end{array}$ & $\begin{array}{c}0.027 \\
(0.023)\end{array}$ \\
\hline Higher edu. & $\begin{array}{c}0.465 * * * \\
(0.010)\end{array}$ & $\begin{array}{c}0.468 * * * \\
(0.010)\end{array}$ & $\begin{array}{c}0.294 * * * \\
(0.012)\end{array}$ & $\begin{array}{c}0.029 \\
(0.036)\end{array}$ & $\begin{array}{c}0.026 \\
(0.035)\end{array}$ & $\begin{array}{c}0.019 \\
(0.035)\end{array}$ \\
\hline City & $\begin{array}{c}-0.120 * * * \\
(0.007)\end{array}$ & $\begin{array}{c}-0.127 * * * \\
(0.007)\end{array}$ & $\begin{array}{c}-0.130 * * * \\
(0.007)\end{array}$ & & & \\
\hline Village & $\begin{array}{c}-0.383^{* * *} \\
(0.008)\end{array}$ & $\begin{array}{c}-0.303^{* * *} \\
(0.009)\end{array}$ & $\begin{array}{c}-0.293 * * * \\
(0.008)\end{array}$ & & & \\
\hline Region dummies & Yes & Yes & Yes & Yes & Yes & Yes \\
\hline Year dummies & Yes & Yes & Yes & Yes & Yes & Yes \\
\hline Sector dummies & No & Yes & Yes & No & Yes & Yes \\
\hline Occupation dummies & No & No & Yes & No & No & Yes \\
\hline Constant & $\begin{array}{c}3.017 * * * \\
(0.037)\end{array}$ & $\begin{array}{c}3.042 * * * \\
(0.039)\end{array}$ & $\begin{array}{c}2.892 * * * \\
(0.039)\end{array}$ & $\begin{array}{c}2.053 * * * \\
(0.427)\end{array}$ & $\begin{array}{c}1.999 * * * \\
(0.420)\end{array}$ & $\begin{array}{c}1.947 * * * \\
(0.416)\end{array}$ \\
\hline Observations & 42430 & 38810 & 38762 & 42430 & 38810 & 38762 \\
\hline $\begin{array}{l}\text { R-squared } \\
\text { Number of groups }\end{array}$ & 0.46 & 0.47 & 0.49 & $\begin{array}{c}0.46 \\
14476\end{array}$ & $\begin{array}{c}0.42 \\
13856\end{array}$ & $\begin{array}{c}0.42 \\
13843\end{array}$ \\
\hline
\end{tabular}

Notes: Robust standard errors in parentheses. * significant at $10 \%$; ${ }^{* *}$ significant at $5 \%$; *** significant at $1 \%$. Wages are deflated by region-specific CPIs, and trimmed (the lowest and the highest $1 \%$ of the distribution). 
Table 11: Hourly wage gap: Informal employees and those not working in enterprise/organization

\begin{tabular}{|c|c|c|c|c|c|c|}
\hline & (1) & $\begin{array}{l}(2) \\
\text { OLS }\end{array}$ & (3) & (4) & $\begin{array}{l}\text { (5) } \\
\text { FE }\end{array}$ & (6) \\
\hline Informal employee & $\begin{array}{c}-0.088^{* * *} \\
(0.014)\end{array}$ & $\begin{array}{c}-0.111^{* * *} \\
(0.014)\end{array}$ & $\begin{array}{c}-0.060 * * * \\
(0.014)\end{array}$ & $\begin{array}{c}0.008 \\
(0.018)\end{array}$ & $\begin{array}{c}-0.018 \\
(0.019)\end{array}$ & $\begin{array}{c}-0.011 \\
(0.019)\end{array}$ \\
\hline No enterpr./org. & $\begin{array}{c}0.037 * * * \\
(0.012)\end{array}$ & $\begin{array}{c}0.005 \\
(0.013)\end{array}$ & $\begin{array}{c}0.017 \\
(0.013)\end{array}$ & $\begin{array}{c}0.063 * * * \\
(0.018)\end{array}$ & $\begin{array}{c}0.036^{* *} \\
(0.018)\end{array}$ & $\begin{array}{c}0.040^{* *} \\
(0.018)\end{array}$ \\
\hline Age & $\begin{array}{c}0.037 * * * \\
(0.002)\end{array}$ & $\begin{array}{c}0.037 * * * \\
(0.002)\end{array}$ & $\begin{array}{c}0.033 * * * \\
(0.002)\end{array}$ & $\begin{array}{c}0.073 * * * \\
(0.016)\end{array}$ & $\begin{array}{c}0.070 * * * \\
(0.016)\end{array}$ & $\begin{array}{c}0.066^{* * *} \\
(0.016)\end{array}$ \\
\hline Age squared & $\begin{array}{c}-0.001^{* * *} \\
(0.000)\end{array}$ & $\begin{array}{c}-0.000^{* * *} \\
(0.000)\end{array}$ & $\begin{array}{c}-0.000^{* * *} \\
(0.000)\end{array}$ & $\begin{array}{c}-0.001^{* * *} \\
(0.000)\end{array}$ & $\begin{array}{c}-0.001^{* * *} \\
(0.000)\end{array}$ & $\begin{array}{c}-0.001^{* * *} \\
(0.000)\end{array}$ \\
\hline Male & $\begin{array}{c}0.300 * * * \\
(0.006)\end{array}$ & $\begin{array}{c}0.233^{* * *} \\
(0.007)\end{array}$ & $\begin{array}{c}0.213^{* * *} \\
(0.008)\end{array}$ & & & \\
\hline Married & $\begin{array}{c}0.065^{* * *} \\
(0.007)\end{array}$ & $\begin{array}{c}0.064 * * * \\
(0.007)\end{array}$ & $\begin{array}{c}0.057 * * * \\
(0.007)\end{array}$ & $\begin{array}{c}0.032 * * \\
(0.015)\end{array}$ & $\begin{array}{c}0.037 * * \\
(0.015)\end{array}$ & $\begin{array}{c}0.038^{* *} \\
(0.015)\end{array}$ \\
\hline Sec. edu. & $\begin{array}{c}0.166^{* * *} \\
(0.010)\end{array}$ & $\begin{array}{c}0.144 * * * \\
(0.009)\end{array}$ & $\begin{array}{c}0.096 * * * \\
(0.009)\end{array}$ & $\begin{array}{c}0.018 \\
(0.025)\end{array}$ & $\begin{array}{c}0.024 \\
(0.025)\end{array}$ & $\begin{array}{c}0.028 \\
(0.025)\end{array}$ \\
\hline Higher edu. & $\begin{array}{c}0.504^{* * *} \\
(0.011)\end{array}$ & $\begin{array}{c}0.494 * * * \\
(0.011)\end{array}$ & $\begin{array}{c}0.304^{* * *} \\
(0.012)\end{array}$ & $\begin{array}{c}0.006 \\
(0.039)\end{array}$ & $\begin{array}{c}0.001 \\
(0.038)\end{array}$ & $\begin{array}{c}-0.007 \\
(0.038)\end{array}$ \\
\hline city & $\begin{array}{c}-0.145^{* * *} \\
(0.008)\end{array}$ & $\begin{array}{c}-0.153^{* * *} \\
(0.008)\end{array}$ & $\begin{array}{c}-0.155^{* * *} \\
(0.008)\end{array}$ & $\begin{array}{c}-0.021 \\
(0.181)\end{array}$ & $\begin{array}{c}-0.072 \\
(0.143)\end{array}$ & $\begin{array}{c}-0.084 \\
(0.147)\end{array}$ \\
\hline village & $\begin{array}{c}-0.439 * * * \\
(0.009)\end{array}$ & $\begin{array}{c}-0.342^{* * *} \\
(0.009)\end{array}$ & $\begin{array}{c}-0.330^{* * *} \\
(0.009)\end{array}$ & & & \\
\hline Region dummies & Yes & Yes & Yes & Yes & Yes & Yes \\
\hline Year dummies & Yes & Yes & Yes & Yes & Yes & Yes \\
\hline Sector dummies & No & Yes & Yes & No & Yes & Yes \\
\hline Occupation dummies & No & No & Yes & No & No & Yes \\
\hline Constant & $\begin{array}{c}2.941^{* * *} \\
(0.039)\end{array}$ & $\begin{array}{c}2.936 * * * \\
(0.041)\end{array}$ & $\begin{array}{c}2.793^{* * *} \\
(0.041)\end{array}$ & $\begin{array}{c}1.773 * * * \\
(0.533)\end{array}$ & $\begin{array}{c}1.847 * * * \\
(0.545)\end{array}$ & $\begin{array}{c}1.821^{* * *} \\
(0.536)\end{array}$ \\
\hline Observations & 47303 & 43153 & 43094 & 47303 & 43153 & 43094 \\
\hline R-squared & 0.45 & 0.45 & 0.47 & 0.42 & 0.38 & 0.38 \\
\hline
\end{tabular}

Notes: Robust standard errors in parentheses. * significant at $10 \%$; ** significant at 5\%; *** significant at $1 \%$. Wages are based on wage in the last 30 days, main job 
Table 12: Hourly wage gap: Informal employees and those not working in an enterprise/organization. Quantile regressions

\begin{tabular}{|c|c|c|c|c|c|c|c|}
\hline & $\begin{array}{c}\text { (1) } \\
\text { 5th quantile }\end{array}$ & $\begin{array}{c}\text { (2) } \\
\text { 10th } \\
\text { quantile }\end{array}$ & $\begin{array}{c}\text { (3) } \\
25 \text { th } \\
\text { quantile }\end{array}$ & $\begin{array}{c}(4) \\
50 \text { th } \\
\text { quantile }\end{array}$ & $\begin{array}{c}(5) \\
75 \text { th } \\
\text { quantile }\end{array}$ & $\begin{array}{c}\text { (6) } \\
\text { 90th } \\
\text { quantile }\end{array}$ & $\begin{array}{c}(7) \\
95 \text { th } \\
\text { quantile }\end{array}$ \\
\hline Informal employee & $\begin{array}{c}-0.146 * * * \\
(0.032)\end{array}$ & $\begin{array}{c}-0.150^{* * * *} \\
(0.022)\end{array}$ & $\begin{array}{c}-0.125^{* * *} \\
(0.016)\end{array}$ & $\begin{array}{c}-0.076 * * * \\
(0.015)\end{array}$ & $\begin{array}{c}-0.004 \\
(0.015)\end{array}$ & $\begin{array}{c}0.031 \\
(0.022)\end{array}$ & $\begin{array}{c}0.050 \\
(0.034)\end{array}$ \\
\hline No enterpr./org & $\begin{array}{c}-0.142 * * * \\
(0.028)\end{array}$ & $\begin{array}{c}-0.143^{* * *} \\
(0.019)\end{array}$ & $\begin{array}{c}-0.068 * * * \\
(0.014)\end{array}$ & $\begin{array}{l}-0.020 \\
(0.013)\end{array}$ & $\begin{array}{c}0.078 * * * \\
(0.013)\end{array}$ & $\begin{array}{c}0.175^{* * *} \\
(0.019)\end{array}$ & $\begin{array}{c}0.274 * * * \\
(0.030)\end{array}$ \\
\hline Age & $\begin{array}{c}0.041^{* * *} * \\
(0.005)\end{array}$ & $\begin{array}{c}0.039 * * * \\
(0.003)\end{array}$ & $\begin{array}{c}0.035^{* * *} \\
(0.002)\end{array}$ & $\begin{array}{c}0.034^{* * *} \\
(0.002)\end{array}$ & $\begin{array}{c}0.031 * * * \\
(0.002)\end{array}$ & $\begin{array}{c}0.030 * * * \\
(0.003)\end{array}$ & $\begin{array}{c}0.026^{* * *} \\
(0.005)\end{array}$ \\
\hline Age squared & $\begin{array}{c}-0.001^{* * *} \\
(0.000)\end{array}$ & $\begin{array}{c}-0.001^{* * *} \\
(0.000)\end{array}$ & $\begin{array}{c}-0.000^{* * *} \\
(0.000)\end{array}$ & $\begin{array}{c}-0.000^{* * *} \\
(0.000)\end{array}$ & $\begin{array}{c}-0.000^{* * *} \\
(0.000)\end{array}$ & $\begin{array}{c}-0.000^{* * *} \\
(0.000)\end{array}$ & $\begin{array}{c}-0.000^{* * *} \\
(0.000)\end{array}$ \\
\hline Male & $\begin{array}{c}0.188 * * * \\
(0.019)\end{array}$ & $\begin{array}{c}0.192 * * * \\
(0.013)\end{array}$ & $\begin{array}{c}0.221 * * * \\
(0.009)\end{array}$ & $\begin{array}{c}0.248 * * * \\
(0.008)\end{array}$ & $\begin{array}{c}0.231 * * * \\
(0.008)\end{array}$ & $\begin{array}{c}0.211^{* * *} \\
(0.012)\end{array}$ & $\begin{array}{c}0.178^{* * *} \\
(0.020)\end{array}$ \\
\hline Married & $\begin{array}{c}0.043^{* * *} \\
(0.017)\end{array}$ & $\begin{array}{c}0.056^{* * *} \\
(0.011)\end{array}$ & $\begin{array}{c}0.058^{* * *} \\
(0.009)\end{array}$ & $\begin{array}{c}0.047 * * * \\
(0.008)\end{array}$ & $\begin{array}{c}0.059 * * * \\
(0.008)\end{array}$ & $\begin{array}{c}0.065^{* * *} \\
(0.011)\end{array}$ & $\begin{array}{c}0.085^{* * *} \\
(0.018)\end{array}$ \\
\hline Sec. edu. & $\begin{array}{l}0.050^{* * *} \\
(0.022)\end{array}$ & $\begin{array}{c}0.060^{* * *} \\
(0.015)\end{array}$ & $\begin{array}{c}0.084 * * * \\
(0.012)\end{array}$ & $\begin{array}{c}0.093 * * * \\
(0.010)\end{array}$ & $\begin{array}{c}0.110^{* * *} \\
(0.010)\end{array}$ & $\begin{array}{c}0.113^{* * *} \\
(0.015)\end{array}$ & $\begin{array}{c}0.100^{* * *} \\
(0.024)\end{array}$ \\
\hline Higher edu. & $\begin{array}{c}0.238 * * * \\
(0.029)\end{array}$ & $\begin{array}{c}0.258^{* * *} \\
(0.020)\end{array}$ & $\begin{array}{c}0.277 * * * \\
(0.015)\end{array}$ & $\begin{array}{c}0.291 * * * \\
(0.013)\end{array}$ & $\begin{array}{c}0.331 * * * \\
(0.013)\end{array}$ & $\begin{array}{c}0.353^{* * *} \\
(0.019)\end{array}$ & $\begin{array}{c}0.327 * * * \\
(0.030)\end{array}$ \\
\hline City & $\begin{array}{c}-0.154^{* * *} \\
(0.019)\end{array}$ & $\begin{array}{c}-0.150 * * * \\
(0.013)\end{array}$ & $\begin{array}{c}-0.171^{* * *} \\
(0.010)\end{array}$ & $\begin{array}{c}-0.172 * * * \\
(0.009)\end{array}$ & $\begin{array}{c}-0.141^{* * *} \\
(0.009)\end{array}$ & $\begin{array}{c}-0.121^{* * *} \\
(0.013)\end{array}$ & $\begin{array}{c}-0.143^{* * *} \\
(0.020)\end{array}$ \\
\hline Village & $\begin{array}{c}-0.332 * * * \\
(0.021)\end{array}$ & $\begin{array}{c}-0.347 * * * \\
(0.014)\end{array}$ & $\begin{array}{c}-0.354^{* * *} \\
(0.011)\end{array}$ & $\begin{array}{c}-0.339 * * * \\
(0.010)\end{array}$ & $\begin{array}{c}-0.294 * * * \\
(0.010)\end{array}$ & $\begin{array}{c}-0.278 * * * \\
(0.015)\end{array}$ & $\begin{array}{c}-0.280^{* * *} \\
(0.023)\end{array}$ \\
\hline Constant & $\begin{array}{c}1.616^{* * *} \\
(0.098)\end{array}$ & $\begin{array}{c}1.944 * * * \\
(0.066)\end{array}$ & $\begin{array}{c}2.398 * * * \\
(0.050)\end{array}$ & $\begin{array}{c}2.794 * * * \\
(0.045)\end{array}$ & $\begin{array}{c}3.202^{* * *} \\
(0.044)\end{array}$ & $\begin{array}{c}3.611^{* * *} \\
(0.065)\end{array}$ & $\begin{array}{c}4.012 * * * \\
(0.102)\end{array}$ \\
\hline Observations & 43094 & 43094 & 43094 & 43094 & 43094 & 43094 & 43094 \\
\hline
\end{tabular}

Notes: Robust standard errors in parentheses. * significant at $10 \%$; ** significant at $5 \%$; ${ }^{* * *}$ significant at $1 \%$. Wages are based on wage in the last 30 days, main job. Additional controls include year, region, sector and occupation dummies. 


\section{FIGURES}

Figure 1: Informal employment and non-employment, 2003-2011

a) Main job

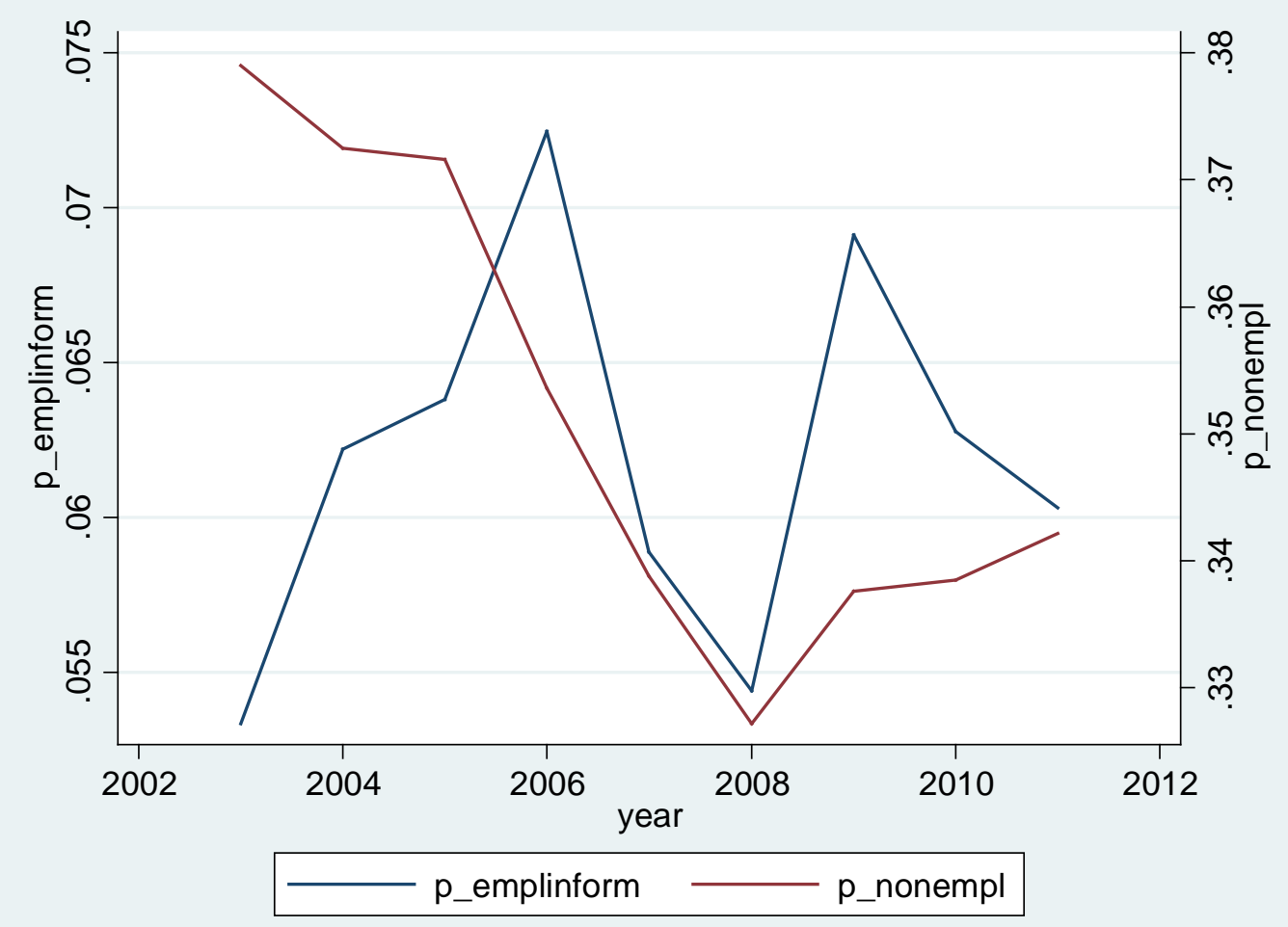

b) Main job, second job, self-employment

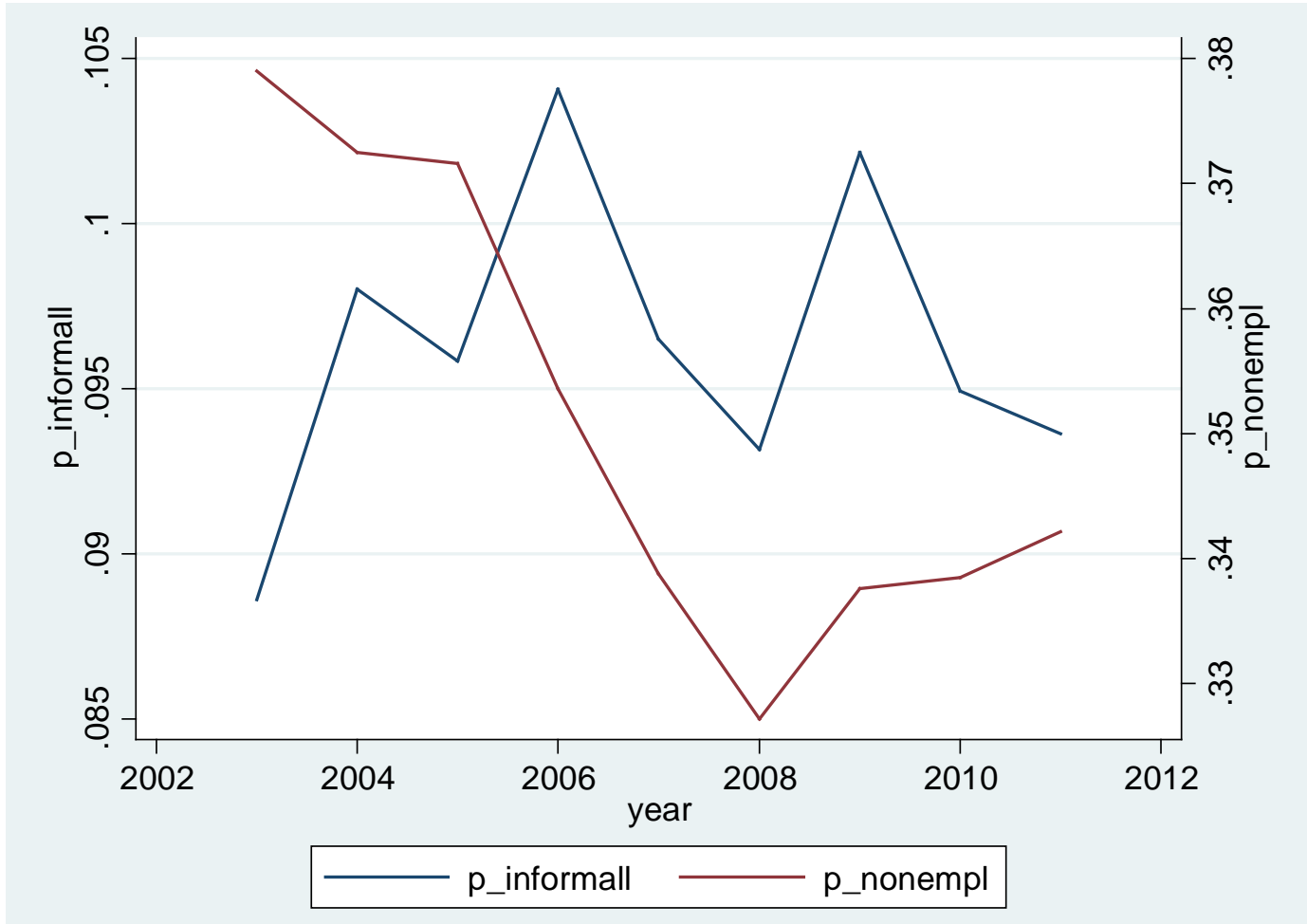


Figure 2: Informal employment and non-employment, 2003-2011

a) Informal employees and not working in enterprise/organization, Main job

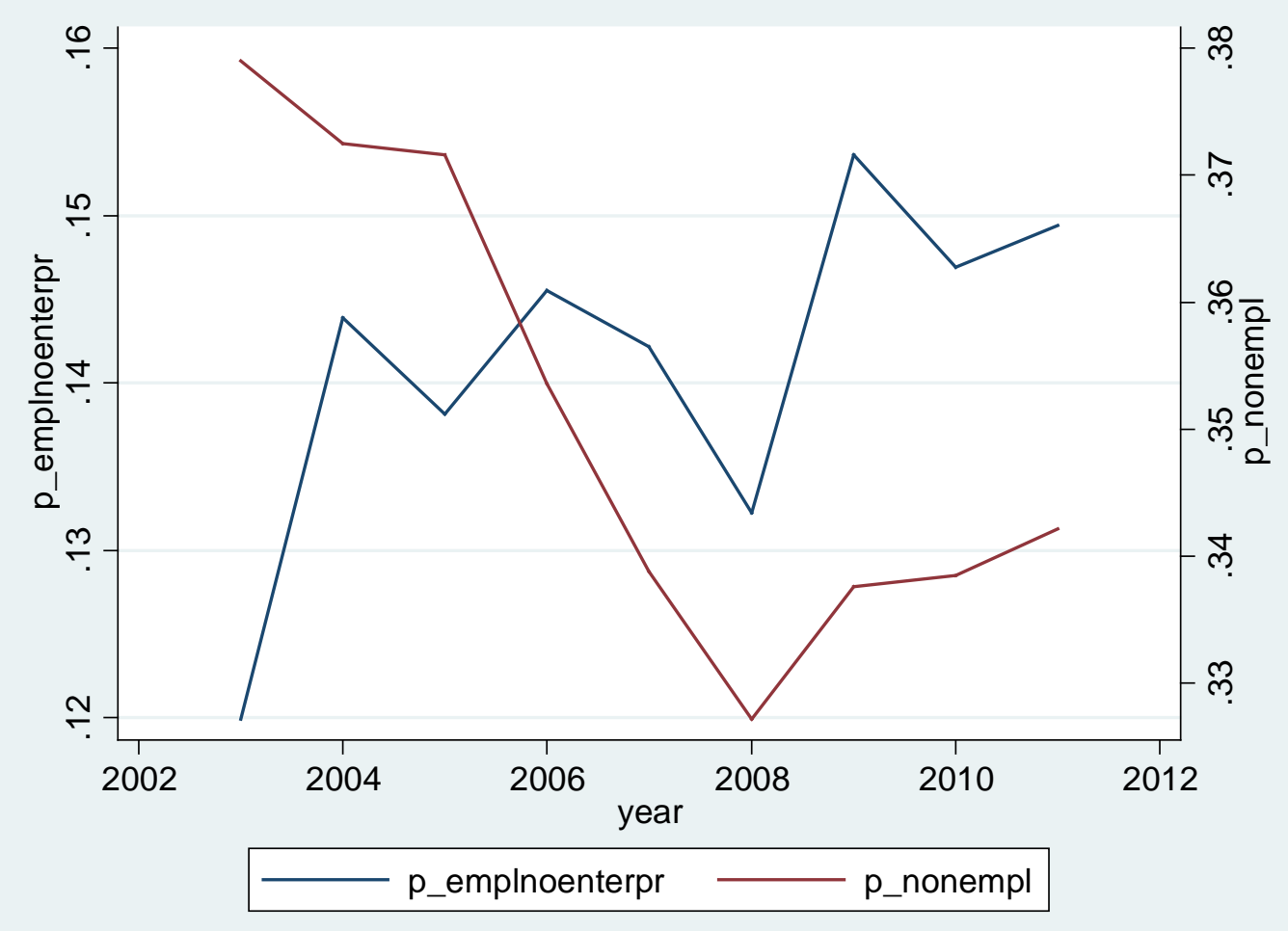

b) Informal employees and not working in enterprise/organization, Main or secondary job

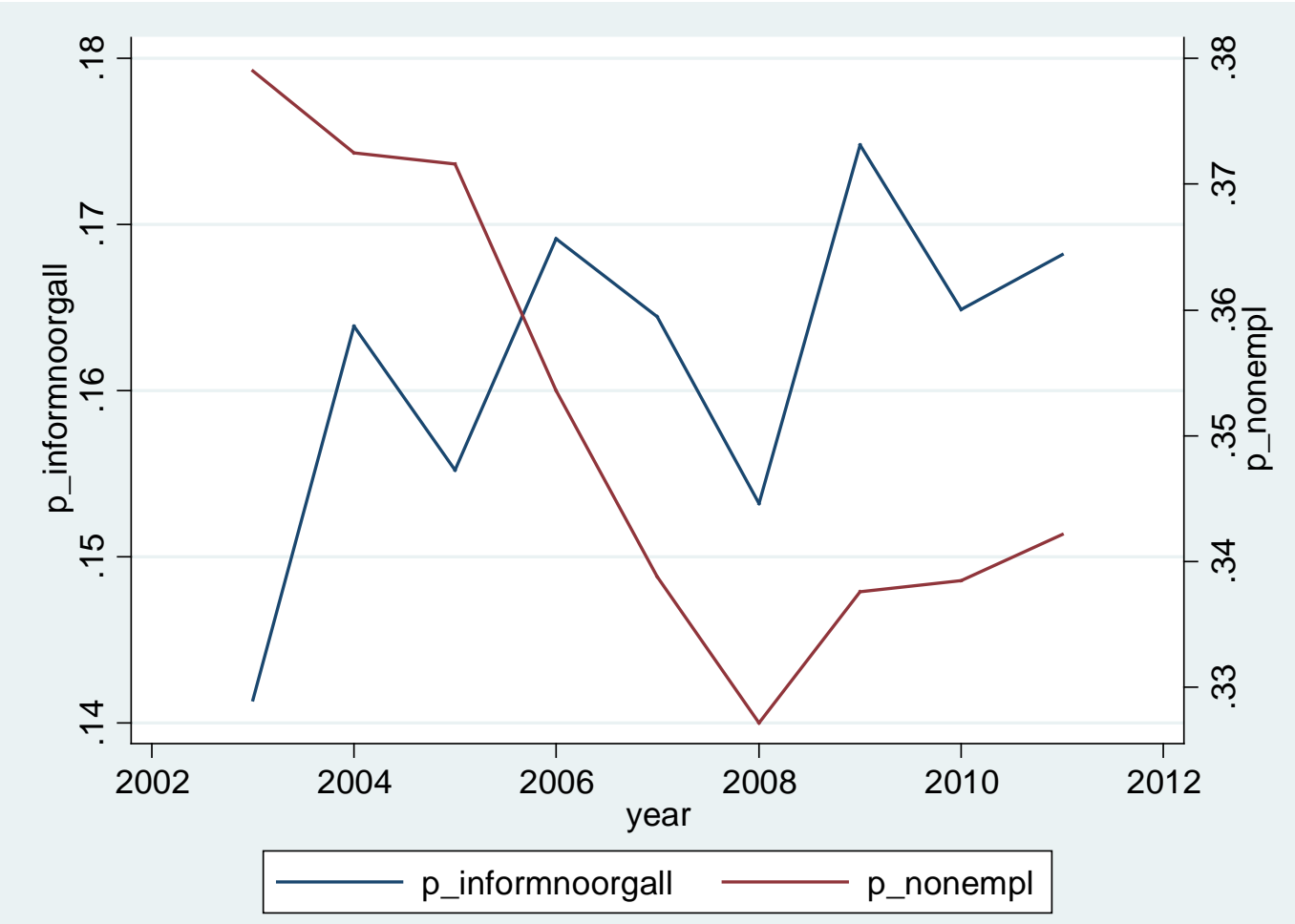


Figure 3: Informality defined by firm size

a) Less than or equal to 5 employees

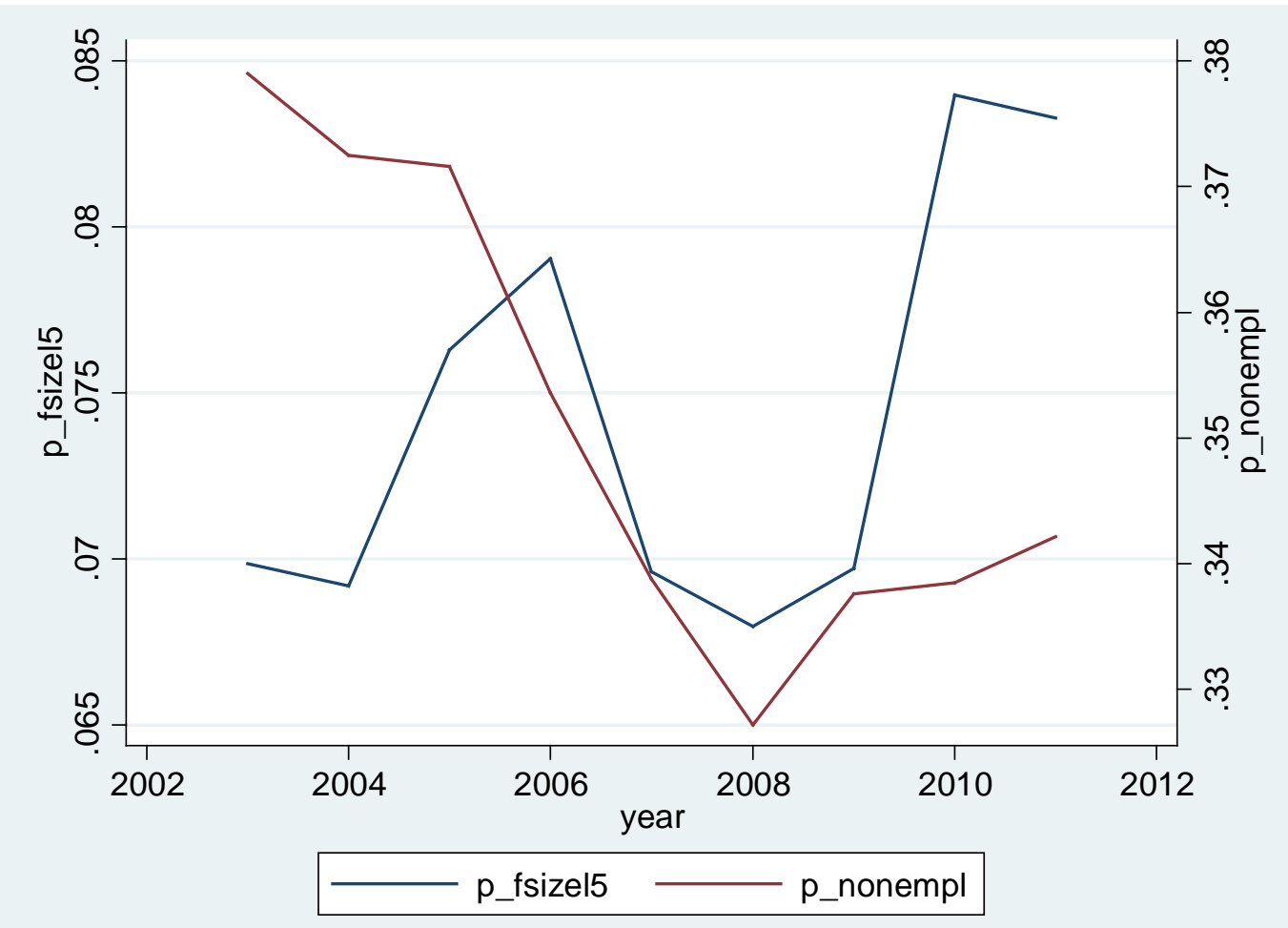

b) Less than or equal to 10 employees

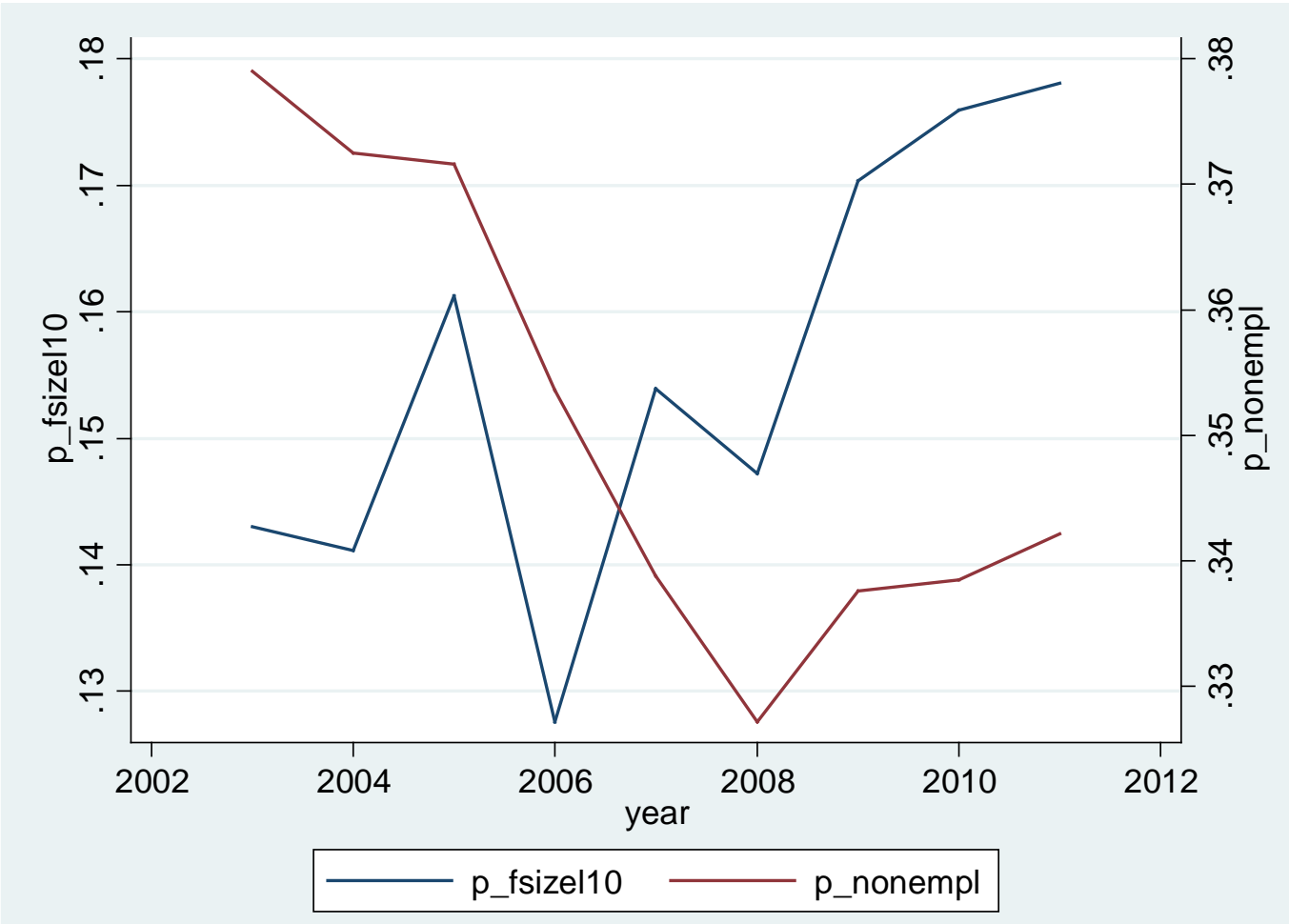


Figure 4: Informal employment defined as lack of provision of benefits, 2003-2011

a) Main job

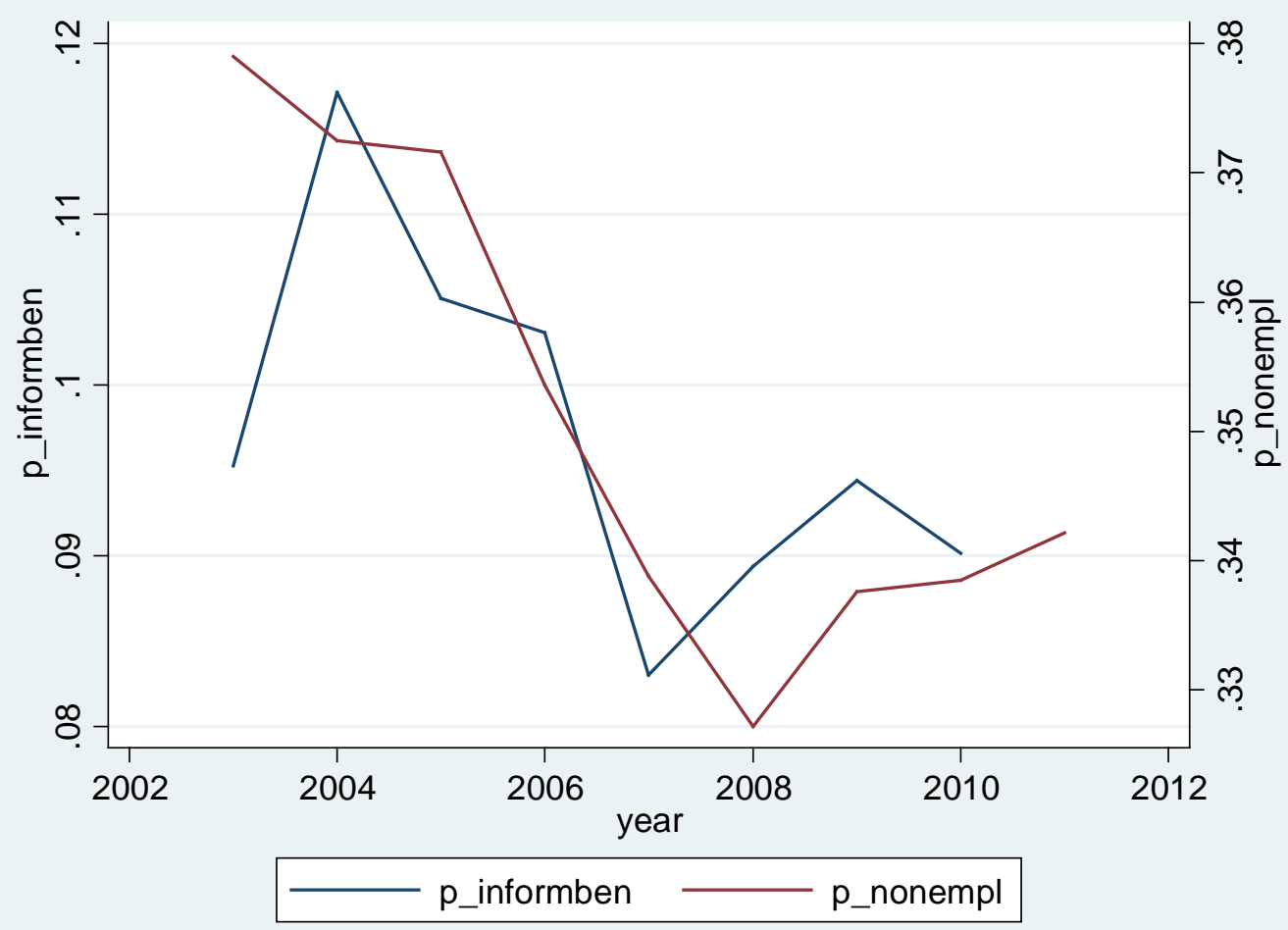

b) Second job

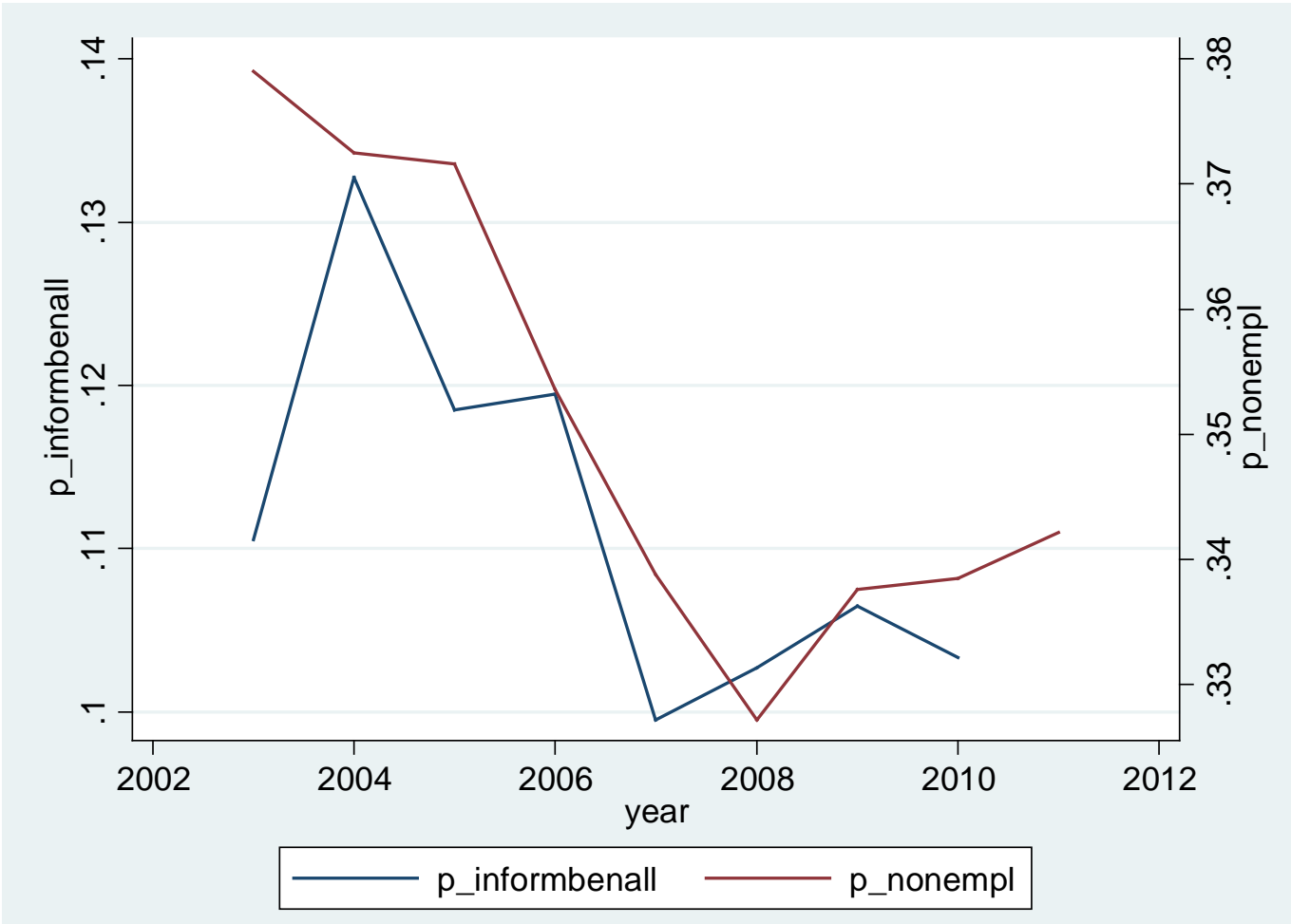


Figure 5: Proportion of informal employment by industry, 2005 and 2011

a) Employed not officially (without work contract/agreement) at the main job

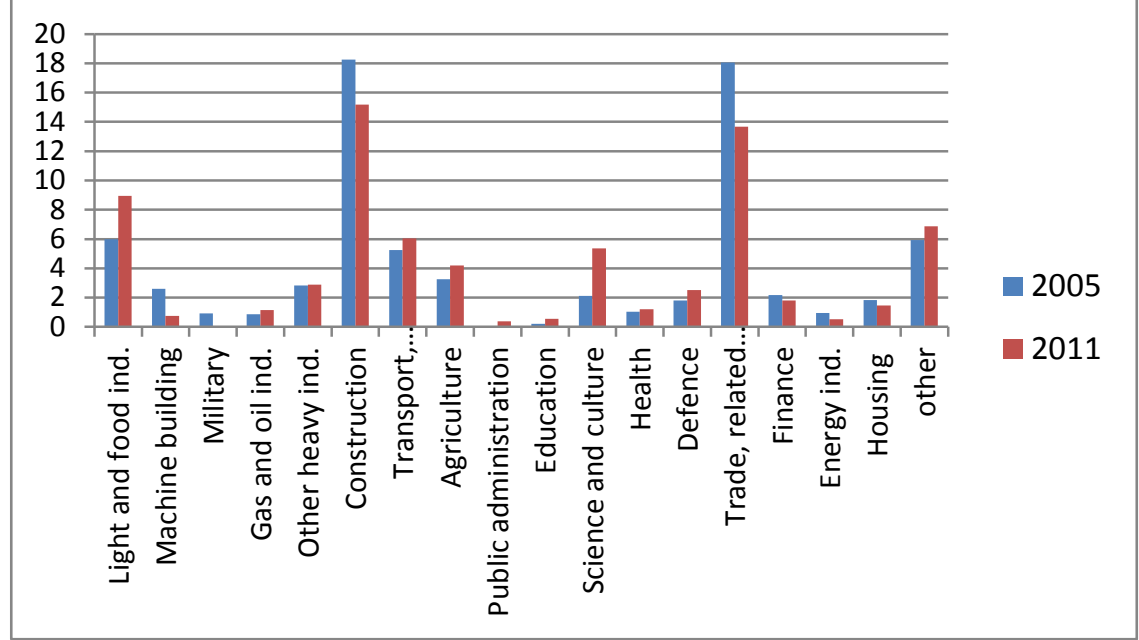

b) Employed not officially at the main job, second job or not officially self-employed

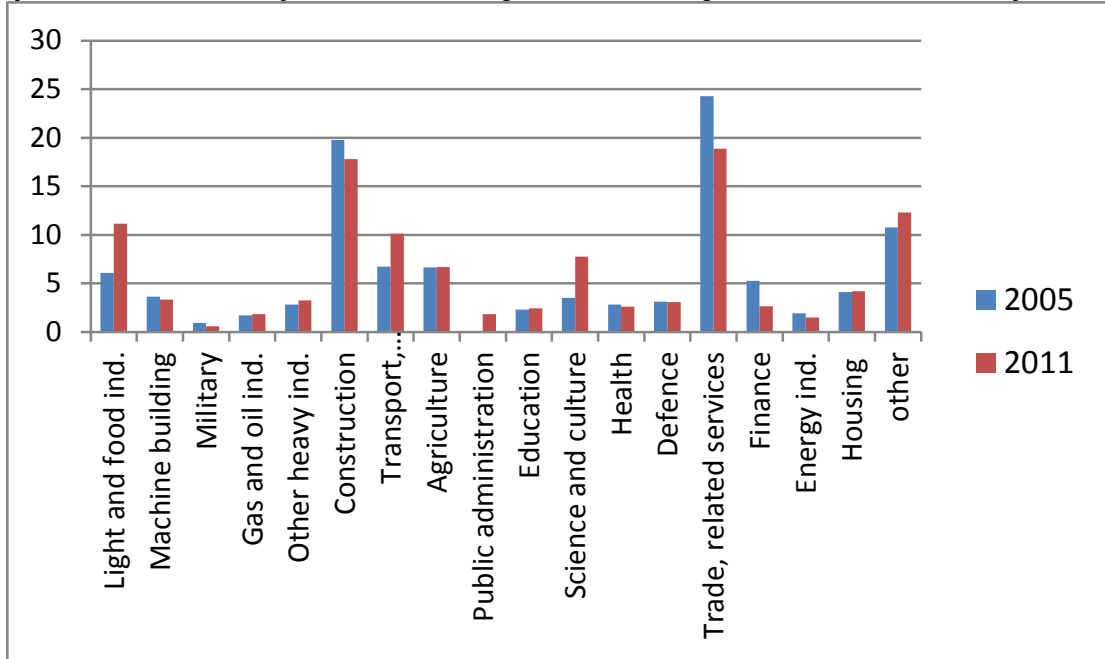

c) Employed not officially and not in enterpr./org. at the main or second job

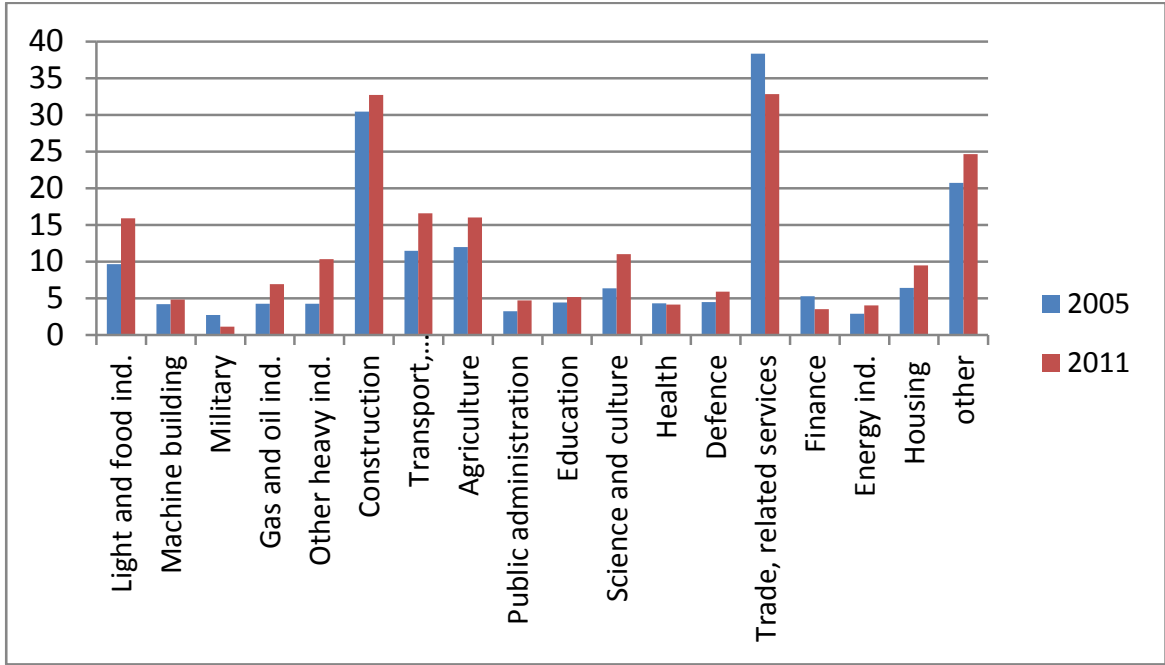

Source: Authors' calculations. Nota bene: these figures have to be interpreted with caution due to very few observations per sector for informal employees and entrepreneurs. 
Figure 6: Proportion of informal employment by occupation, 2005 and 2011

a) Employed not officially (without work contract/agreement) at the main job

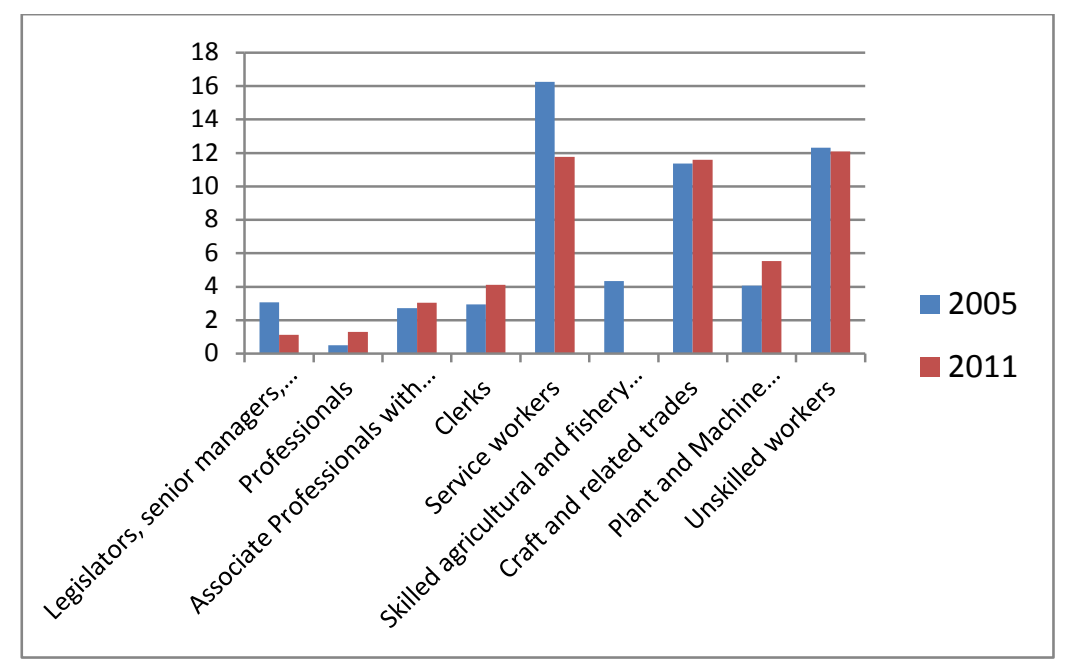

b) Employed not officially at the main job, second job or not officially self-employed

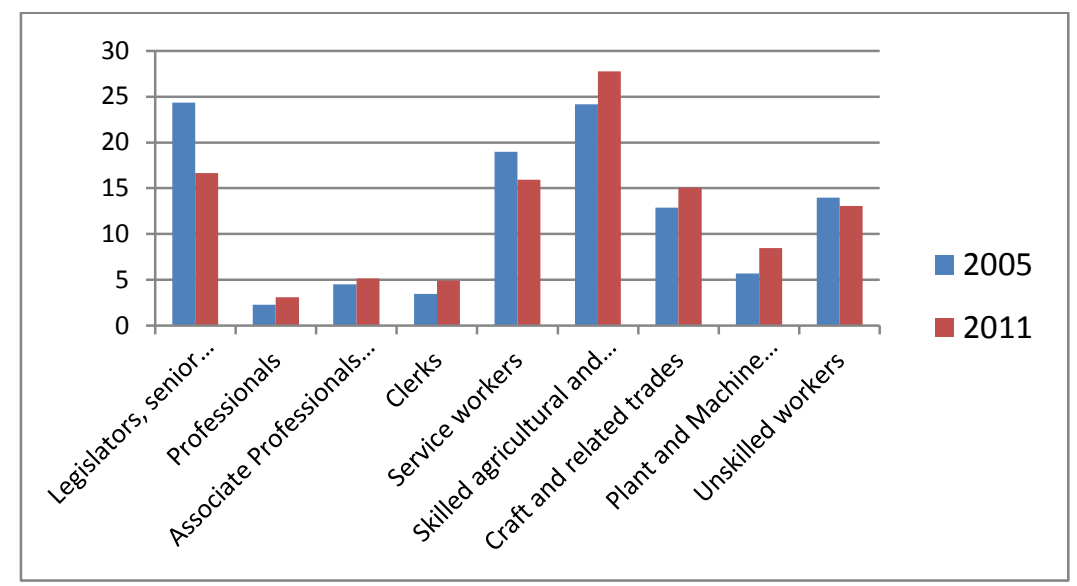

c) Employed not officially and not in enterpr./org. at the main or second job

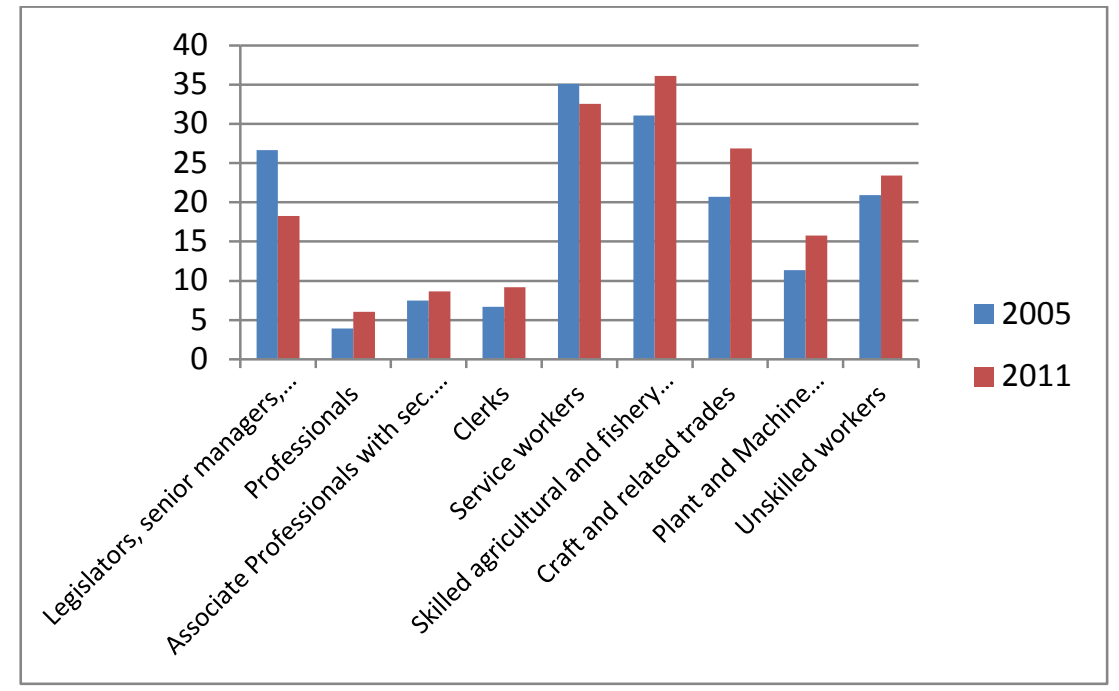

Source: Authors' calculations. 
Figure 7: Informality as defined by firm size by sectors:

a) Equal or less than 5 employees

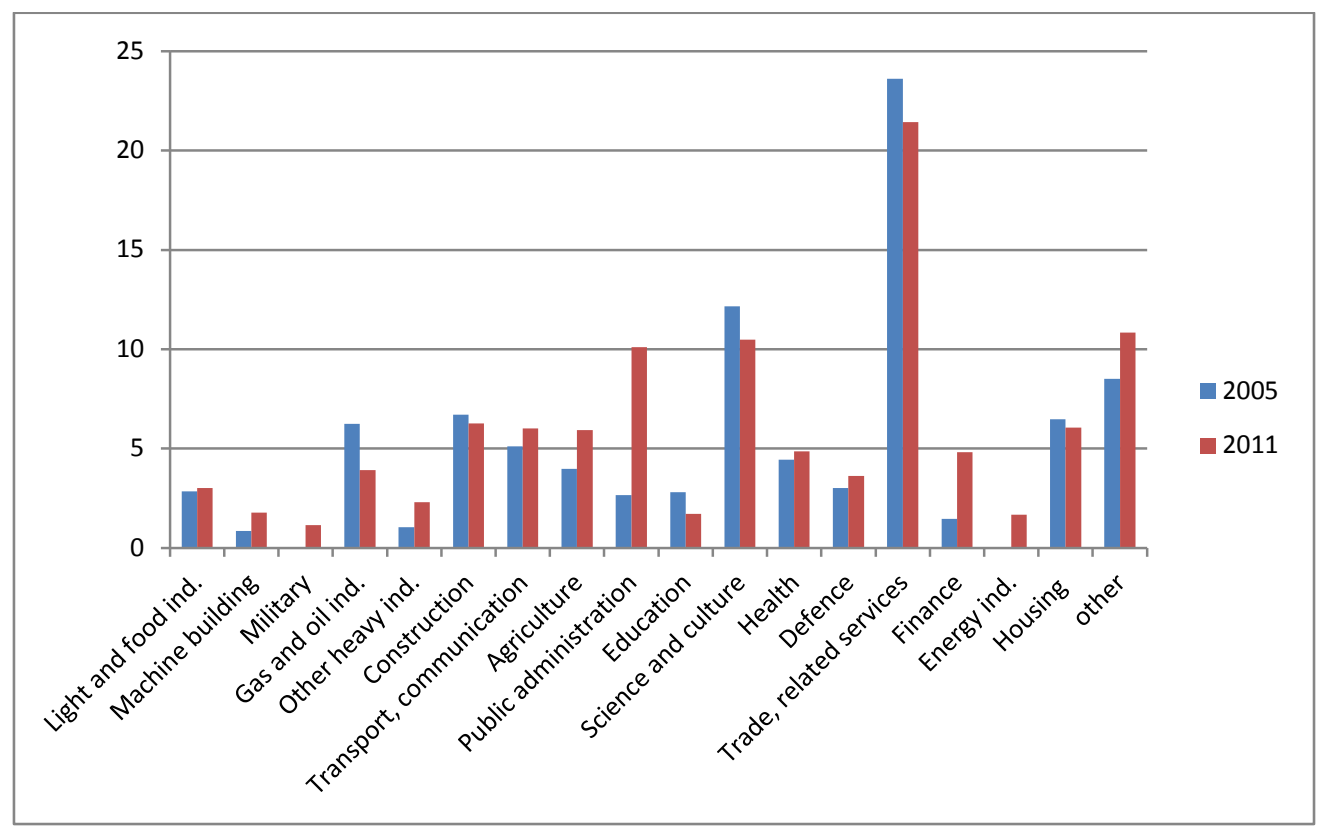

b) Equal or less than 10 employees

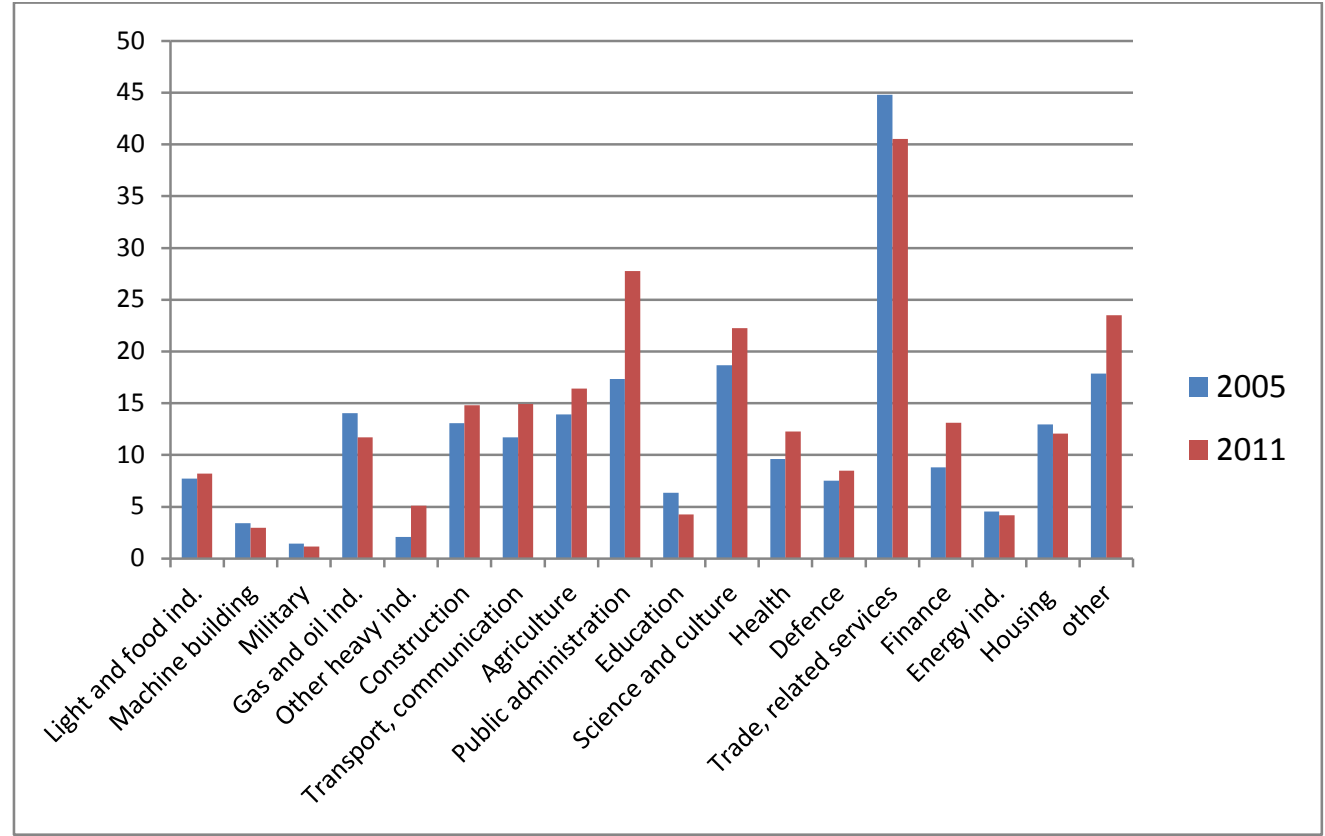

Source: Authors’ calculations. 
Figure 8: Informality as defined by firm size by occupations:

a) Equal or less than 5 employees

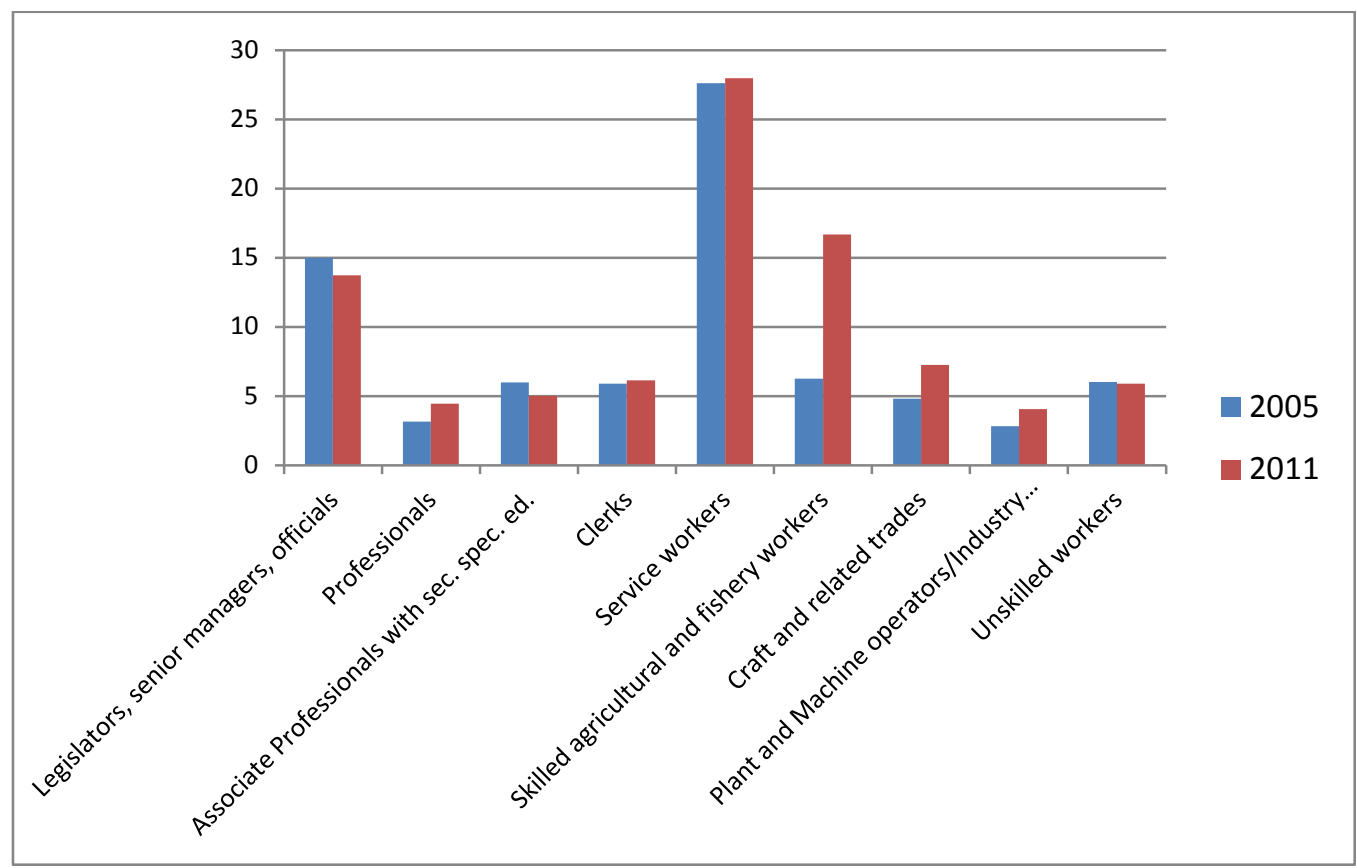

b) Equal or less than 10 employees

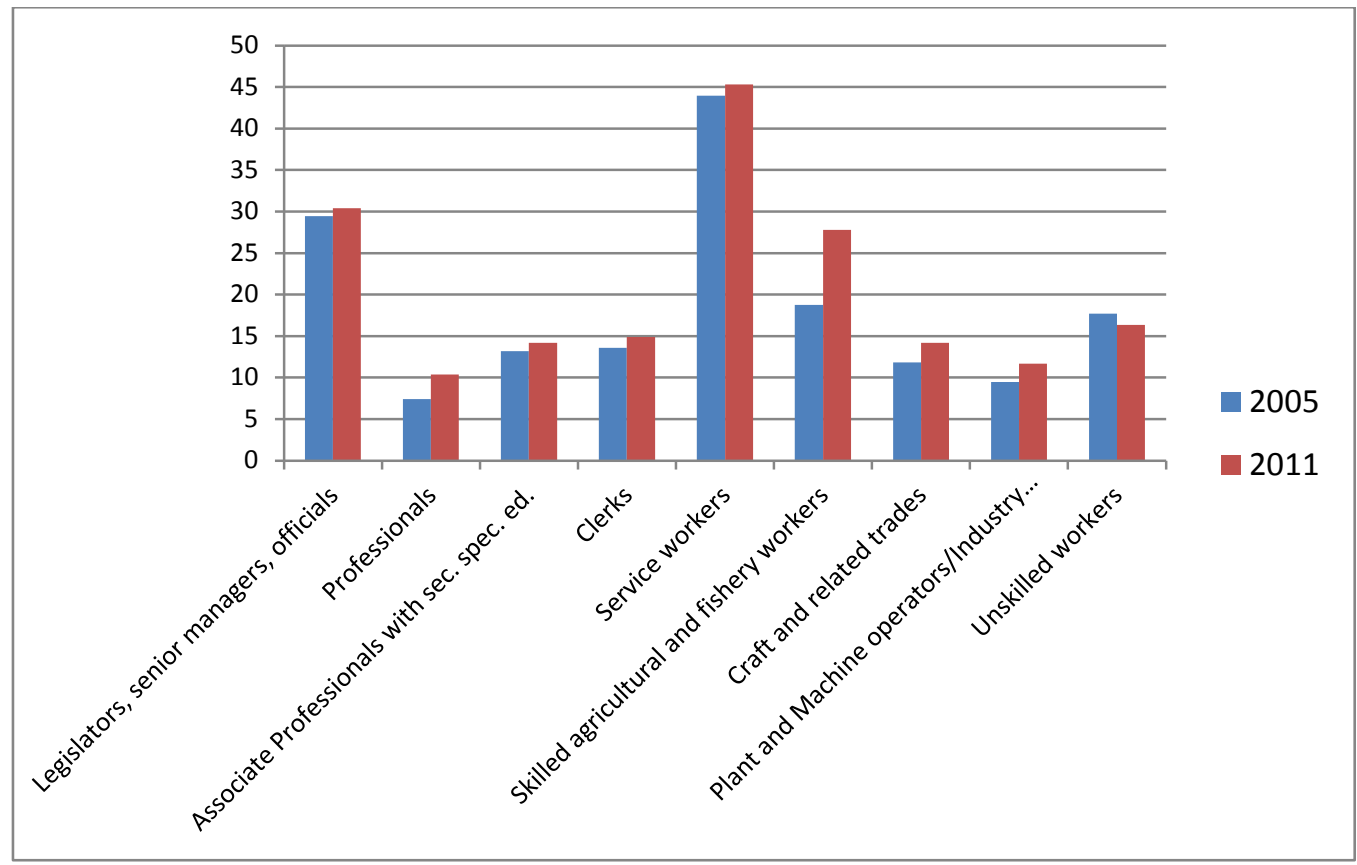

Source: Authors’ calculations. 
Figure 9: General risk attitudes and employment state - 2009

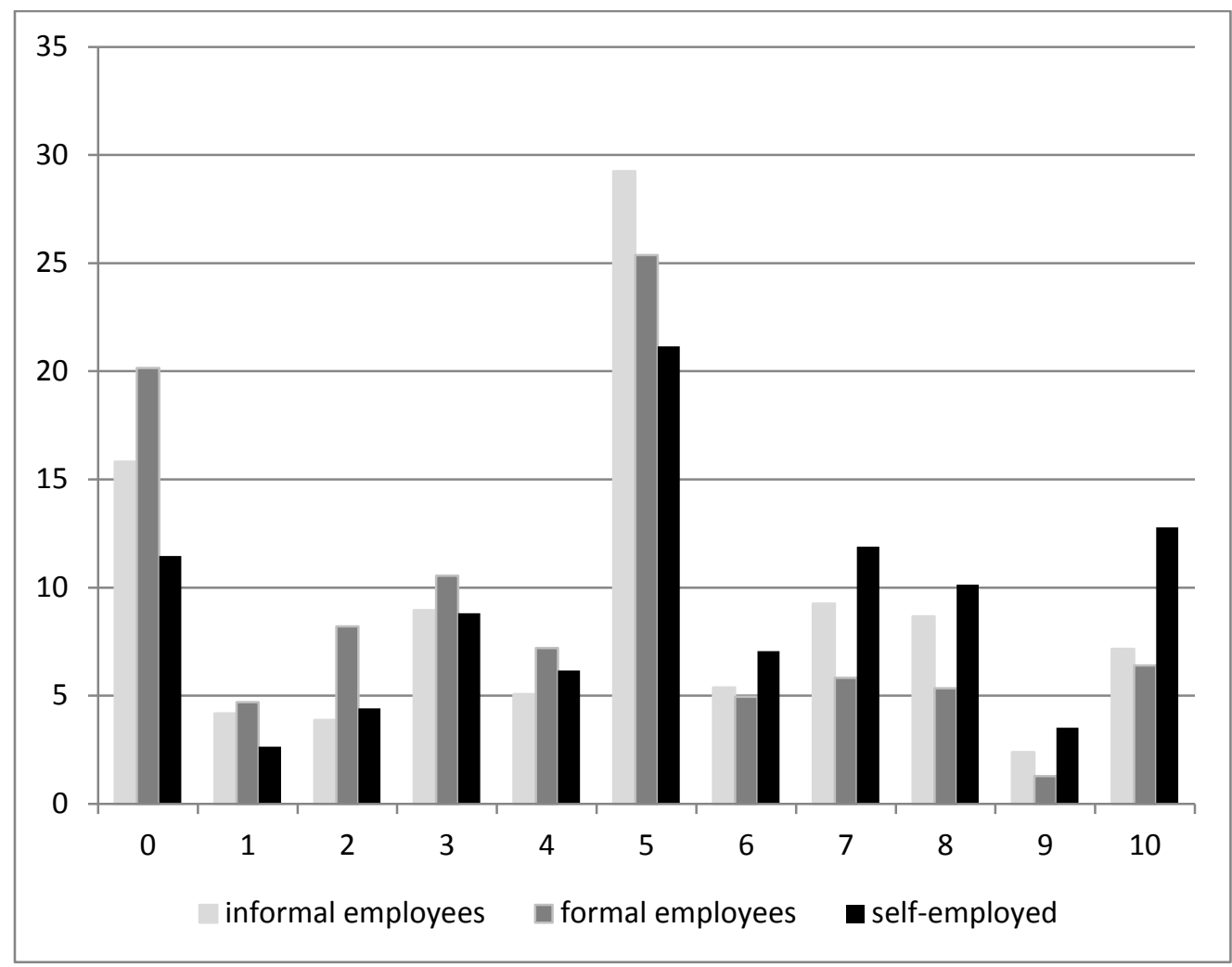

Notes: final sample used in the regressions.

Figure 10: Risk attitudes in financial domain and employment state - 2009

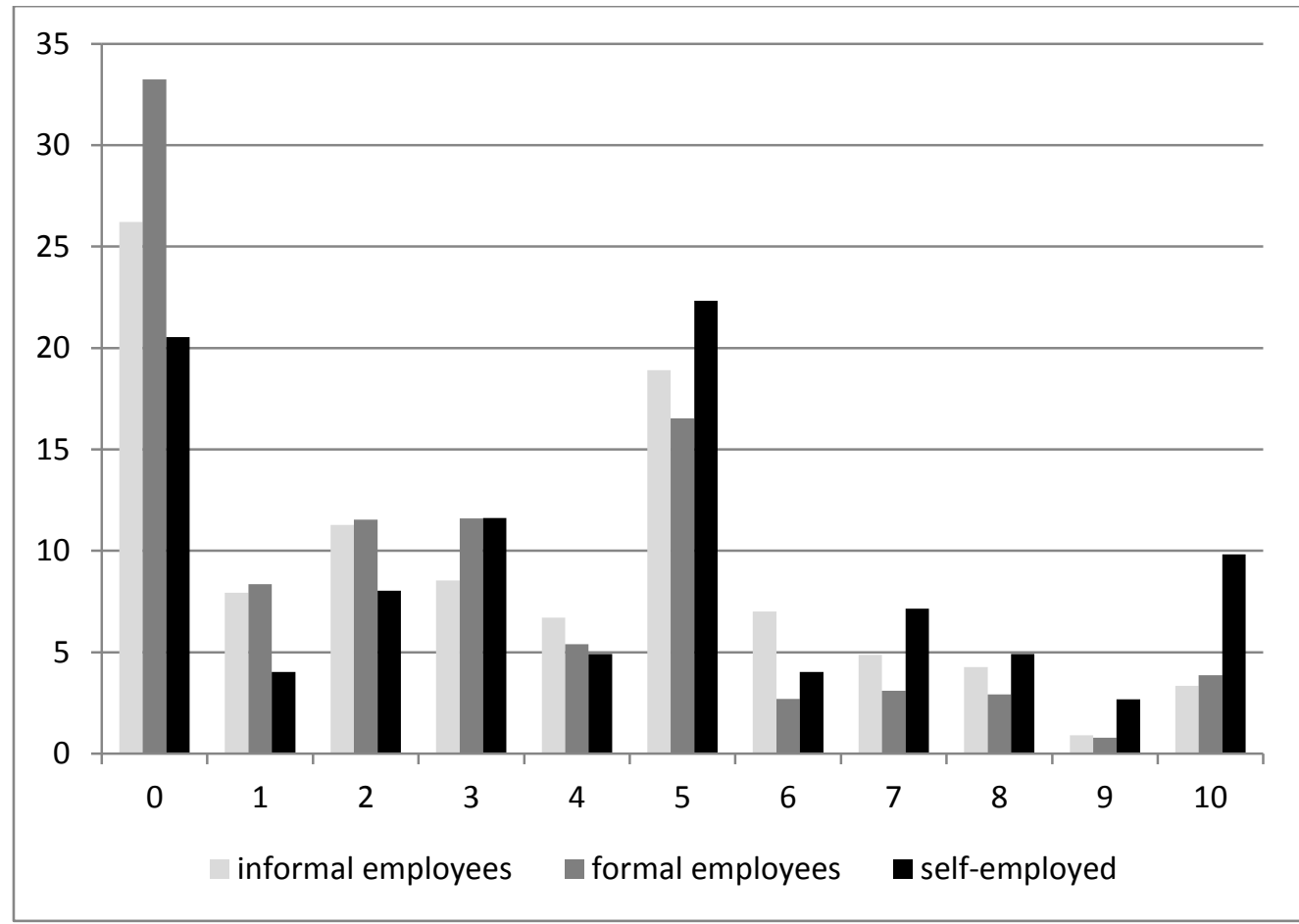

Source: Authors’ calculation based on RLMS informality supplement 2009. 
Figure 11: Hourly wage gap: Coefficients from quantile regressions, 2004-2011

a) Informal employees

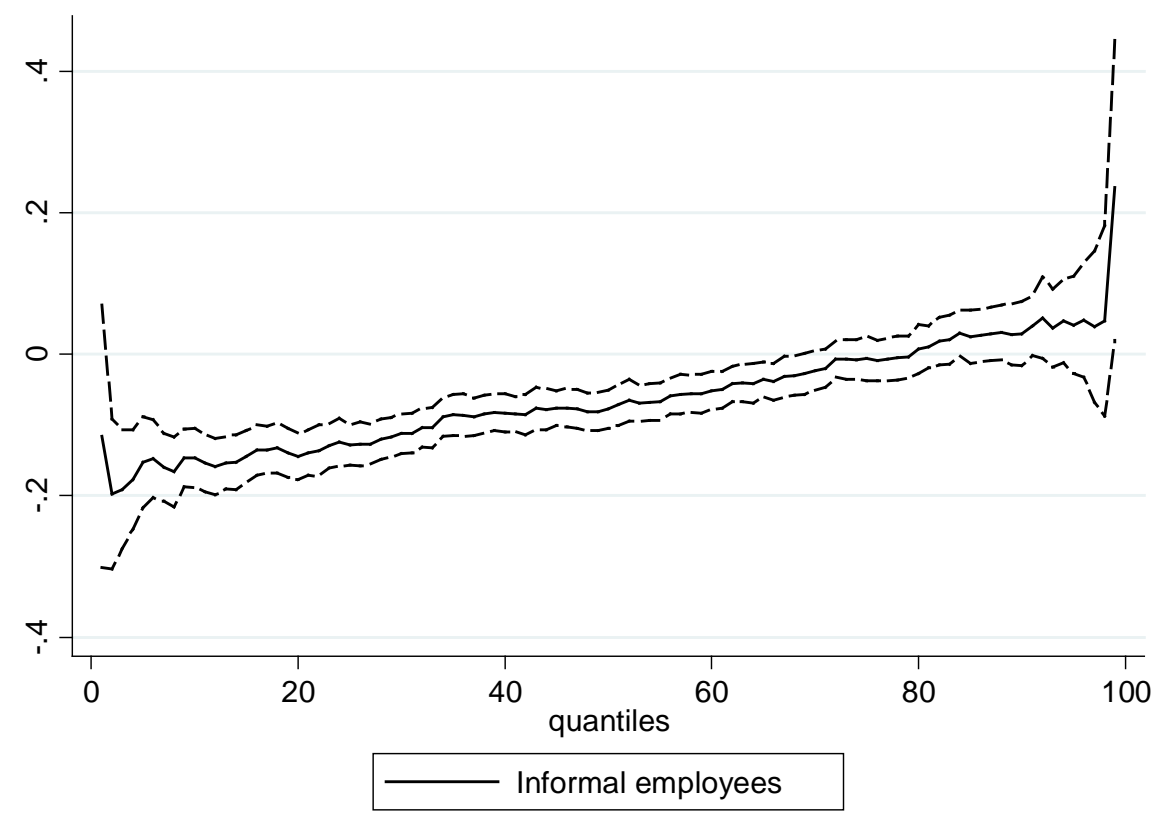

b) Informal employees and not working in enterpr./organization

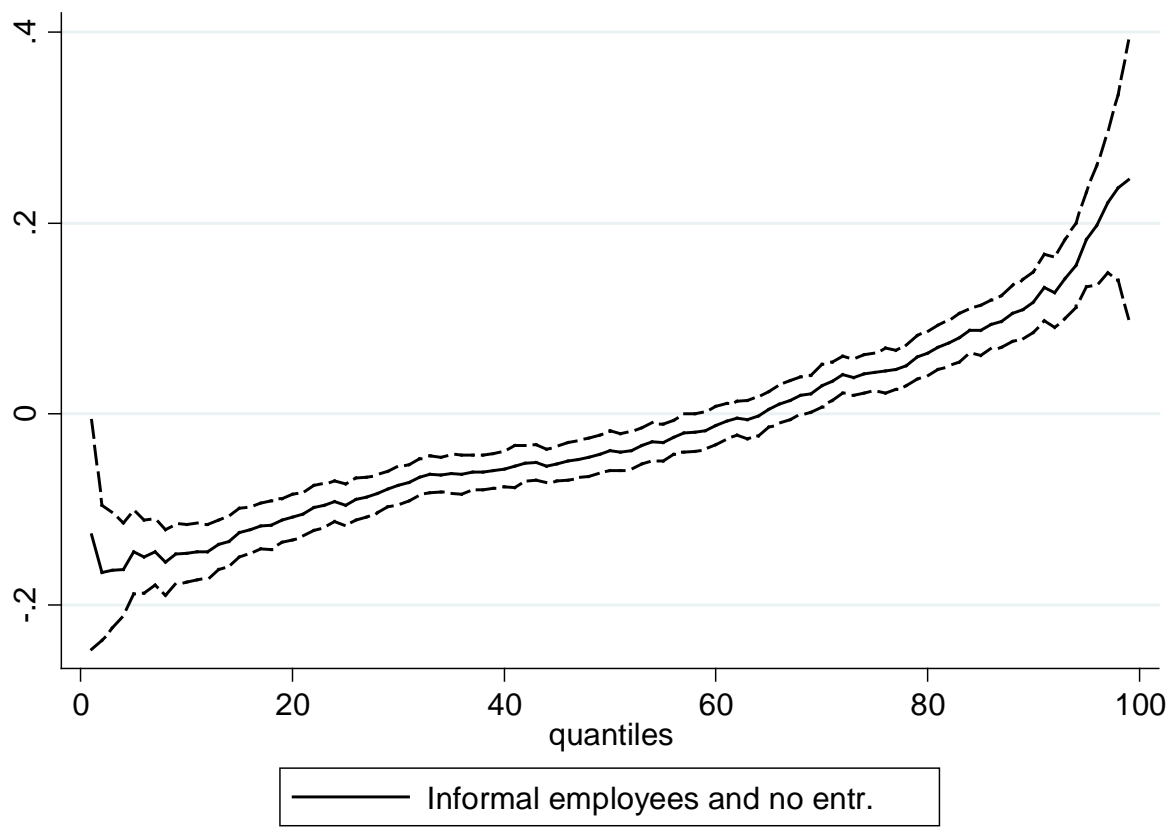

Source: Authors’ calculations based on RLMS waves 2003-20011. 


\section{APPENDIX}

Table A1: Characteristics of employees by informality status (at the main job), 2003 and 2011

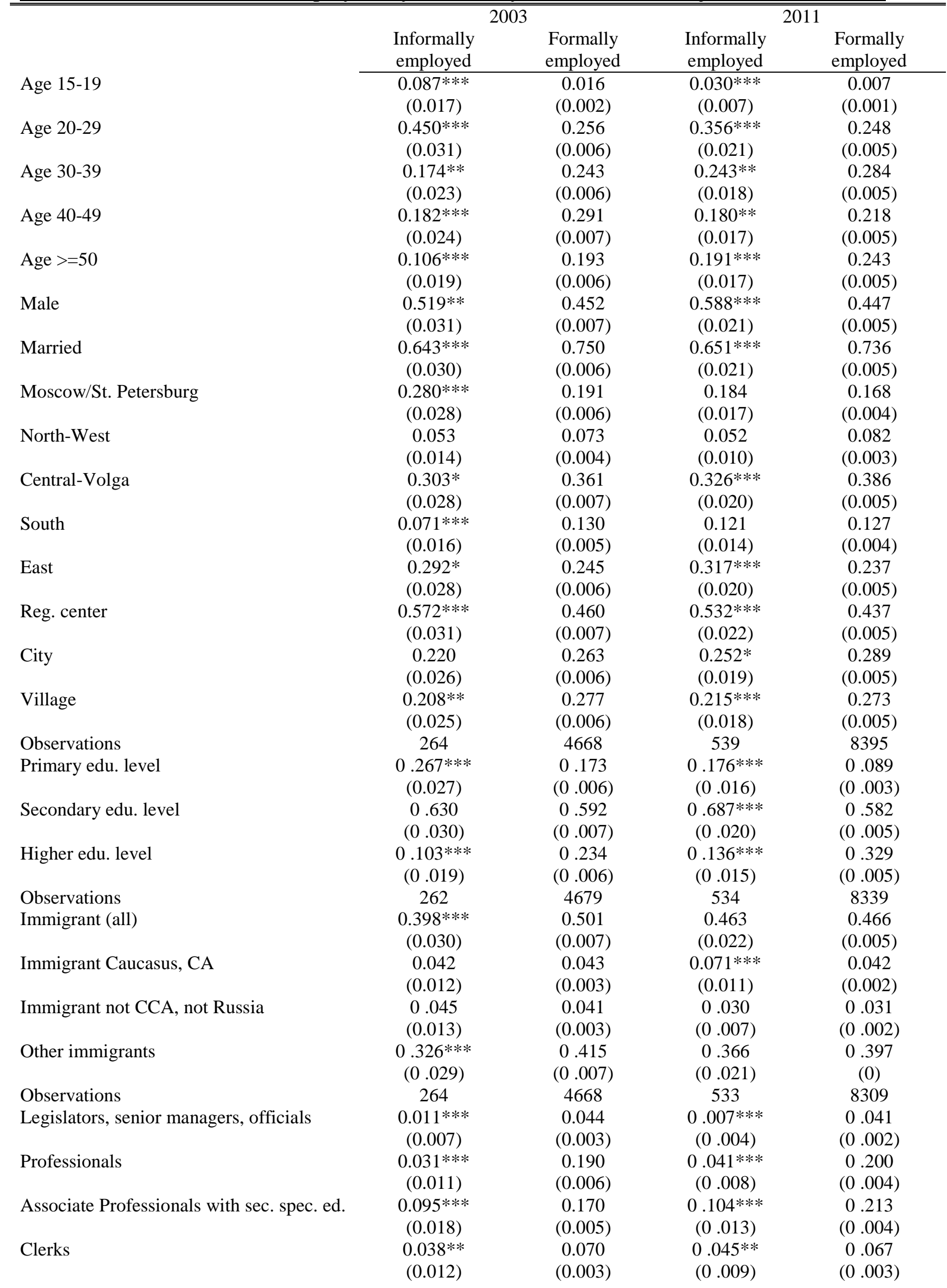


Service workers

Skilled agricultural and fishery workers

Craft and related trades

Plant and Machine operators/Industry

workers

Unskilled workers

Light and food ind.

Machine building

Military

Gas and oil ind.

Other heavy ind.

Construction

Transport, communication

Agriculture

Public administration

Education

Science and culture

Health

Defence

Trade, related services

Finance

Energy ind.

Housing

Other ind.

Observations
Observations

\begin{tabular}{|c|c|}
\hline $0.251 * * *$ & 0.088 \\
\hline$(0.027)$ & $(0.004)$ \\
\hline 0 & 0.005 \\
\hline & $(0.001)$ \\
\hline $0.210 * * *$ & 0.130 \\
\hline$(0.025)$ & $(0.005)$ \\
\hline 0.164 & 0.175 \\
\hline$(0.023)$ & $(0.006)$ \\
\hline $0.198 * * *$ & 0.127 \\
\hline$(0.025)$ & (0.005) \\
\hline 262 & 4676 \\
\hline 0.067 & 0.072 \\
\hline (0.014) & (0.003) \\
\hline $0.016 * *$ & 0.041 \\
\hline (0.007) & $(0.003)$ \\
\hline $0.003^{* *}$ & 0.024 \\
\hline (0.003) & $(0.002)$ \\
\hline $0.003^{* *}$ & 0.025 \\
\hline (0.003) & $(0.002)$ \\
\hline $0.013^{*}$ & 0.030 \\
\hline$(0.006)$ & (0.003) \\
\hline $0.236 * * *$ & 0.072 \\
\hline$(0.024)$ & $(0.004)$ \\
\hline 0.081 & 0.100 \\
\hline$(0.015)$ & $(0.004)$ \\
\hline $0.029 * *$ & 0.059 \\
\hline$(0.010)$ & $(0.004)$ \\
\hline 0 & 0.020 \\
\hline & (0.002) \\
\hline $0.003^{* * *}$ & 0.104 \\
\hline (0.003) & $(0.004)$ \\
\hline $0.010 * *$ & 0.030 \\
\hline$(0.006)$ & (0.003) \\
\hline $0.013^{* * *}$ & 0.085 \\
\hline$(0.006)$ & $(0.004)$ \\
\hline $0.013^{* * *}$ & 0.048 \\
\hline$(0.006)$ & (0.003) \\
\hline $0.427 * * *$ & 0.132 \\
\hline$(0.028)$ & $(0.005)$ \\
\hline $0.006 *$ & 0.020 \\
\hline$(0.005)$ & $(0.002)$ \\
\hline $0.003^{* *}$ & 0.023 \\
\hline (0.003) & $(0.002)$ \\
\hline 0.013 & 0.047 \\
\hline$(0.006)$ & (0.003) \\
\hline 0.061 & 0.067 \\
\hline$(0.014)$ & $(0.004)$ \\
\hline 309 & 4529 \\
\hline
\end{tabular}

0.101

(0.003)

0.003

(0.001)

$0.229 * * * \quad 0.112$

$(0.018) \quad(0.003)$

$0.147 \quad 0.161$

$(0.015) \quad(0.004)$

$0.217^{* * *} \quad 0.101$

$(0.018) \quad(0.003)$

$538 \quad 8378$

$0.087 * * * \quad 0.057$

$(0.012) \quad(0.003)$

$0.004 * * * \quad 0.032$

$(0.003) \quad(0.002)$

$0 * * * \quad 0.020$

$0.006 * * * \quad 0.031$

$(0.003) \quad(0.002)$

0.019 ** $\quad 0.040$

$(0.006) \quad(0.002)$

$0.201^{* * *} \quad 0.072$

$(0.017) \quad(0.003)$

$0.095 \quad 0.094$

$(0.013) \quad(0.003)$

$0.033 \quad 0.049$

$(0.008) \quad(0.002)$

$0.002^{* * *} \quad 0.032$

$(0.002) \quad(0.002)$

$0.009 * * * \quad 0.109$

$(0.004) \quad(0.003)$

$0.030 \quad 0.034$

$(0.007) \quad(0.002)$

$0.017^{* * *} \quad 0.089$

$(0.006) \quad(0.003)$

$0.020 * * * \quad 0.051$

$(0.006) \quad(0.002)$

$0.429 * * * \quad 0.174$

$(0.021) \quad(0.004)$

$0.007^{* * *} \quad 0.026$

$(0.004) \quad(0.002)$

$0.002 * * * \quad 0.023$

$(0.002) \quad(0.002)$

$0.009 * * * \quad 0.040$

$(0.004) \quad(0.002)$

$0.030 \quad 0.026$

$(0.007) \quad(0.002)$

$538 \quad 8386$

Notes: authors' calculations from the RLMS dataset. Means are reported. Standard errors are in parentheses. *, **, *** denotes that the difference in means is statistically significant at the 10, 5 and 1 percent level, respectively. Tabulations by industry is from 2005 instead of 2003 due to missing information on industry in 2003 and missing energy industry in 2004. Primary edu. level refers to primary level (0-6 years) and non-finished secondary level (7-9 years); secondary edu. level refers to completed secondary and secondary professional / special level; higher edu. level refers to completed higher education and above (master / doctorate etc.). Education is corrected backwards, that is, in cases of inconsistencies across years, if the level in the subsequent year is lower, the level in the preceding year is replaced with this lower level. Immigrants are individuals who were born in a place other than their current place of residence (timevariant). The variables Immigrants Caucasus, CA, Immigrants not CCA not Russia, and Other immigrants are based on a question "In which republic of the ex-USSR you were born" and refer to those born in Caucasus and Central Asian republics, other ex-USSR republics or other countries apart for Caucasus, central Asia or Russia, and in Russia. 
Table A2: Determinants of informal employment in main job: marginal effects.

\begin{tabular}{|c|c|c|c|c|}
\hline & $\begin{array}{c}(1) \\
\text { Emplinform, } \\
\text { Probit }\end{array}$ & $\begin{array}{c}(2) \\
\text { Emplinform, } \\
\text { Probit }\end{array}$ & $\begin{array}{c}(3) \\
\text { Emplinform, } \\
\text { Probit }\end{array}$ & $\begin{array}{c}(4) \\
\text { Emplinform, } \\
\text { Probit }\end{array}$ \\
\hline Age & $\begin{array}{c}-0.001 * * * \\
(0.000)\end{array}$ & $\begin{array}{c}-0.001^{* * *} \\
(0.000)\end{array}$ & $\begin{array}{c}-0.001^{* * *} \\
(0.000)\end{array}$ & $\begin{array}{c}-0.001 * * * \\
(0.000)\end{array}$ \\
\hline Male & $\begin{array}{c}0.021^{* * *} \\
(0.002)\end{array}$ & $\begin{array}{c}0.012 * * * \\
(0.002)\end{array}$ & $\begin{array}{c}0.014^{* * *} \\
(0.002)\end{array}$ & $\begin{array}{c}0.012 * * * \\
(0.002)\end{array}$ \\
\hline Married & $\begin{array}{c}-0.021 * * * \\
(0.002)\end{array}$ & $\begin{array}{c}-0.012^{* * *} \\
(0.002)\end{array}$ & $\begin{array}{c}-0.012 * * * \\
(0.002)\end{array}$ & $\begin{array}{c}-0.013 * * * \\
(0.002)\end{array}$ \\
\hline Sec. edu. level & $\begin{array}{c}-0.021 * * * \\
(0.003)\end{array}$ & $\begin{array}{c}-0.006 * * * \\
(0.002)\end{array}$ & $\begin{array}{c}-0.005^{* *} \\
(0.002)\end{array}$ & $\begin{array}{c}-0.006 * * * \\
(0.002)\end{array}$ \\
\hline High edu. level & $\begin{array}{c}-0.057 * * * \\
(0.002)\end{array}$ & $\begin{array}{c}-0.015^{* * *} \\
(0.002)\end{array}$ & $\begin{array}{c}-0.017 * * * \\
(0.003)\end{array}$ & $\begin{array}{c}-0.015 * * * \\
(0.002)\end{array}$ \\
\hline North-West & $\begin{array}{c}-0.021^{* * *} \\
(0.003)\end{array}$ & $\begin{array}{c}-0.008 * * * \\
(0.003)\end{array}$ & $\begin{array}{c}-0.011 * * * \\
(0.003)\end{array}$ & $\begin{array}{c}-0.007 * * * \\
(0.003)\end{array}$ \\
\hline Central-Volga & $\begin{array}{c}-0.016^{* * * *} \\
(0.002)\end{array}$ & $\begin{array}{c}-0.010^{* * *} \\
(0.002)\end{array}$ & $\begin{array}{c}-0.010 * * * \\
(0.002)\end{array}$ & $\begin{array}{c}-0.008 * * * \\
(0.002)\end{array}$ \\
\hline South & $\begin{array}{c}-0.011 * * * \\
(0.003)\end{array}$ & $\begin{array}{c}-0.009 * * * \\
(0.002)\end{array}$ & $\begin{array}{c}-0.006^{* *} \\
(0.003)\end{array}$ & $\begin{array}{c}-0.008 * * * \\
(0.002)\end{array}$ \\
\hline East & $\begin{array}{c}0.003 \\
(0.003)\end{array}$ & $\begin{array}{c}0.004 * * \\
(0.002)\end{array}$ & $\begin{array}{l}0.004^{*} \\
(0.003)\end{array}$ & $\begin{array}{c}0.005 * * \\
(0.002)\end{array}$ \\
\hline City & $\begin{array}{c}-0.018 * * * \\
(0.002)\end{array}$ & $\begin{array}{c}-0.009 * * * \\
(0.001)\end{array}$ & $\begin{array}{c}-0.010 * * * \\
(0.002)\end{array}$ & $\begin{array}{c}-0.010 * * * \\
(0.001)\end{array}$ \\
\hline Village & $\begin{array}{c}-0.028 * * * \\
(0.002)\end{array}$ & $\begin{array}{c}-0.014^{* * *} \\
(0.002)\end{array}$ & $\begin{array}{c}-0.015^{* * *} \\
(0.002)\end{array}$ & $\begin{array}{c}-0.015^{* * *} \\
(0.002)\end{array}$ \\
\hline Immigrant & & & $\begin{array}{c}0.009 * * * \\
(0.002)\end{array}$ & \\
\hline $\begin{array}{l}\text { Immigrant } \\
\text { Caucasus,CA }\end{array}$ & & & & $0.024^{* * *}$ \\
\hline $\begin{array}{l}\text { Immigrants not } \\
\text { CCA, not Russia }\end{array}$ & & & & $\begin{array}{c}(0.005) \\
0.028^{* * *} \\
(0.006)\end{array}$ \\
\hline Other immigrants & & & & $\begin{array}{c}0.004^{* *} \\
(0.002)\end{array}$ \\
\hline y2003 & $\begin{array}{c}-0.008^{*} \\
(0.004)\end{array}$ & & & \\
\hline y2005 & $\begin{array}{c}0.002 \\
(0.004)\end{array}$ & $\begin{array}{c}-0.000 \\
(0.003)\end{array}$ & $\begin{array}{c}0.001 \\
(0.009)\end{array}$ & $\begin{array}{c}0.000 \\
(0.003)\end{array}$ \\
\hline y2006 & $\begin{array}{c}0.011 * * \\
(0.005)\end{array}$ & $\begin{array}{c}0.008 * * \\
(0.003)\end{array}$ & $\begin{array}{c}0.005 \\
(0.007)\end{array}$ & $\begin{array}{c}0.009 * * * \\
(0.003)\end{array}$ \\
\hline y2007 & $\begin{array}{l}-0.000 \\
(0.004)\end{array}$ & $\begin{array}{c}-0.000 \\
(0.003)\end{array}$ & $\begin{array}{c}0.005 \\
(0.009)\end{array}$ & $\begin{array}{c}0.000 \\
(0.003)\end{array}$ \\
\hline y2008 & $\begin{array}{c}-0.004 \\
(0.004)\end{array}$ & $\begin{array}{c}-0.004 \\
(0.003)\end{array}$ & $\begin{array}{l}-0.007 \\
(0.005)\end{array}$ & $\begin{array}{c}-0.003 \\
(0.003)\end{array}$ \\
\hline y2009 & $\begin{array}{c}0.013 * * * \\
(0.005)\end{array}$ & $\begin{array}{c}0.007 * * \\
(0.003)\end{array}$ & $\begin{array}{c}0.003 \\
(0.006)\end{array}$ & $\begin{array}{c}0.007 * * \\
(0.003)\end{array}$ \\
\hline y2010 & $\begin{array}{c}0.009 * * \\
(0.004)\end{array}$ & $\begin{array}{c}0.004 \\
(0.003)\end{array}$ & $\begin{array}{c}0.001 \\
(0.005)\end{array}$ & $\begin{array}{c}0.005 \\
(0.003)\end{array}$ \\
\hline y2011 & $\begin{array}{l}0.007^{*} \\
(0.004)\end{array}$ & $\begin{array}{c}0.003 \\
(0.003)\end{array}$ & $\begin{array}{c}-0.000 \\
(0.005)\end{array}$ & $\begin{array}{c}0.004 \\
(0.003)\end{array}$ \\
\hline Machine building & & $\begin{array}{c}-0.023 * * * \\
(0.002)\end{array}$ & $\begin{array}{c}-0.023^{* * *} \\
(0.002)\end{array}$ & $\begin{array}{c}-0.022 * * * \\
(0.002)\end{array}$ \\
\hline Military & & $\begin{array}{c}-0.029 * * * \\
(0.001)\end{array}$ & $\begin{array}{c}-0.029 * * * \\
(0.002)\end{array}$ & $\begin{array}{c}-0.029 * * * \\
(0.001)\end{array}$ \\
\hline Gas and oil ind. & & $\begin{array}{c}-0.028 * * * \\
(0.001)\end{array}$ & $\begin{array}{c}-0.028 * * * \\
(0.002)\end{array}$ & $\begin{array}{c}-0.028 * * * \\
(0.001)\end{array}$ \\
\hline Other heavy ind. & & $\begin{array}{c}-0.024^{* * *} \\
(0.002)\end{array}$ & $\begin{array}{c}-0.025^{* * *} \\
(0.002)\end{array}$ & $\begin{array}{c}-0.024 * * * \\
(0.002)\end{array}$ \\
\hline
\end{tabular}




\begin{tabular}{|c|c|c|c|c|}
\hline & & (2) & (3) & (4) \\
\hline \multirow[t]{2}{*}{ Construction } & & $0.024 * * *$ & $0.018^{* * *}$ & $0.023 * * *$ \\
\hline & & $(0.004)$ & $(0.005)$ & $(0.004)$ \\
\hline \multirow{2}{*}{$\begin{array}{l}\text { Transport, } \\
\text { communication }\end{array}$} & & $-0.007 * * *$ & $-0.008 * * *$ & $-0.008 * * *$ \\
\hline & & $(0.002)$ & $(0.003)$ & $(0.002)$ \\
\hline \multirow{2}{*}{ Agriculture } & & $-0.018 * * *$ & $-0.018 * * *$ & $-0.017 * * *$ \\
\hline & & $(0.002)$ & $(0.003)$ & $(0.002)$ \\
\hline \multirow{2}{*}{$\begin{array}{l}\text { Public } \\
\text { administration }\end{array}$} & & $-0.025 * * *$ & $-0.025 * * *$ & $-0.025 * * *$ \\
\hline & & $(0.002)$ & $(0.003)$ & $(0.002)$ \\
\hline \multirow[t]{2}{*}{ Education } & & $-0.032 * * *$ & $-0.033 * * *$ & $-0.031 * * *$ \\
\hline & & $(0.001)$ & $(0.002)$ & $(0.001)$ \\
\hline \multirow[t]{2}{*}{ Science and culture } & & $-0.006^{*}$ & -0.007 & $-0.007 *$ \\
\hline & & $(0.004)$ & $(0.005)$ & $(0.004)$ \\
\hline \multirow[t]{2}{*}{ Health } & & $-0.029 * * *$ & $-0.029 * * *$ & $-0.029 * * *$ \\
\hline & & $(0.001)$ & $(0.002)$ & $(0.001)$ \\
\hline \multirow[t]{2}{*}{ Defence } & & $-0.028 * * *$ & $-0.029 * * *$ & $-0.028 * * *$ \\
\hline & & $(0.001)$ & $(0.002)$ & $(0.001)$ \\
\hline \multirow{2}{*}{$\begin{array}{l}\text { Trade, related } \\
\text { services }\end{array}$} & & $0.025 * * *$ & $0.022^{* * *}$ & $0.025 * * *$ \\
\hline & & $(0.004)$ & $(0.004)$ & $(0.004)$ \\
\hline \multirow[t]{2}{*}{ Finance } & & $-0.018^{* * *}$ & $-0.017 * * *$ & $-0.018 * * *$ \\
\hline & & $(0.003)$ & $(0.004)$ & $(0.003)$ \\
\hline \multirow[t]{2}{*}{ Energy ind. } & & $-0.028 * * *$ & $-0.029 * * *$ & $-0.027 * * *$ \\
\hline & & $(0.001)$ & $(0.002)$ & $(0.001)$ \\
\hline \multirow[t]{2}{*}{ Housing } & & $-0.024 * * *$ & $-0.024 * * *$ & $-0.024^{* * *}$ \\
\hline & & $(0.002)$ & $(0.002)$ & $(0.002)$ \\
\hline \multirow[t]{2}{*}{ Other ind. } & & $0.012 * *$ & $0.017 * *$ & $0.011^{*}$ \\
\hline & & $(0.006)$ & $(0.008)$ & $(0.006)$ \\
\hline \multirow{2}{*}{$\begin{array}{l}\text { Legislators, senior } \\
\text { managers, officials }\end{array}$} & & $-0.030 * * *$ & $-0.030 * * *$ & $-0.029 * * *$ \\
\hline & & $(0.001)$ & $(0.001)$ & $(0.001)$ \\
\hline \multirow[t]{2}{*}{ Professionals } & & $-0.038 * * *$ & $-0.039 * * *$ & $-0.037 * * *$ \\
\hline & & $(0.002)$ & $(0.002)$ & $(0.002)$ \\
\hline \multirow{2}{*}{$\begin{array}{l}\text { Assoc. Profess. with } \\
\text { sec. spec. ed. }\end{array}$} & & $-0.030 * * *$ & $-0.032 * * *$ & $-0.029 * * *$ \\
\hline & & $(0.001)$ & $(0.002)$ & $(0.001)$ \\
\hline \multirow[t]{2}{*}{ Clerks } & & $-0.029 * * *$ & $-0.028 * * *$ & $-0.028 * * *$ \\
\hline & & $(0.001)$ & $(0.002)$ & $(0.001)$ \\
\hline \multirow[t]{2}{*}{ Service workers } & & $-0.010 * * *$ & $-0.013 * * *$ & $-0.010 * * *$ \\
\hline & & $(0.002)$ & $(0.002)$ & $(0.002)$ \\
\hline \multirow{2}{*}{$\begin{array}{l}\text { Skilled agricultural } \\
\text { and fishery workers }\end{array}$} & & $-0.023 * * *$ & $-0.023 * * *$ & $-0.022 * * *$ \\
\hline & & $(0.004)$ & $(0.005)$ & $(0.004)$ \\
\hline \multirow{2}{*}{$\begin{array}{l}\text { Craft and related } \\
\text { trades }\end{array}$} & & $-0.014 * * *$ & $-0.014^{* * *}$ & $-0.013 * * *$ \\
\hline & & $(0.002)$ & $(0.002)$ & $(0.002)$ \\
\hline \multirow{2}{*}{$\begin{array}{l}\text { Plant/Machine } \\
\text { operators/Ind. w-s }\end{array}$} & & $-0.022 * * *$ & $-0.022 * * *$ & $-0.021 * * *$ \\
\hline & & $(0.001)$ & $(0.002)$ & $(0.001)$ \\
\hline Observations & 56330 & 50996 & 32018 & 50438 \\
\hline
\end{tabular}

Notes: Robust standard errors in parentheses. ${ }^{*}$ significant at $10 \%$; ${ }^{* *}$ significant at $5 \%$; ${ }^{* * *}$ significant at $1 \%$.

Reference categories are: female, not married, primary edu. level, Moscow/St. Petersburg, large regional center, nonimmigrants, year 2004, Light and food industry, Unskilled workers. 
Table A3: Determinants of informal employment - main, secondary jobs or self-employed: marginal effects.

\begin{tabular}{|c|c|c|c|c|}
\hline & $\begin{array}{c}(1) \\
\text { informall, } \\
\text { Probit }\end{array}$ & $\begin{array}{c}(2) \\
\text { informall, } \\
\text { Probit }\end{array}$ & $\begin{array}{c}\text { (3) } \\
\text { informall, } \\
\text { Probit }\end{array}$ & $\begin{array}{c}\text { (4) } \\
\text { informall, } \\
\text { Probit }\end{array}$ \\
\hline Age & $\begin{array}{c}-0.001 * * * \\
(0.000)\end{array}$ & $\begin{array}{c}-0.001 * * * \\
(0.000)\end{array}$ & $\begin{array}{c}-0.001 * * * \\
(0.000)\end{array}$ & $\begin{array}{c}-0.001 * * * \\
(0.000)\end{array}$ \\
\hline Male & $\begin{array}{c}0.028 * * * \\
(0.002)\end{array}$ & $\begin{array}{c}0.019 * * * \\
(0.003)\end{array}$ & $\begin{array}{c}0.023 * * * \\
(0.003)\end{array}$ & $\begin{array}{c}0.018 * * * \\
(0.003)\end{array}$ \\
\hline Married & $\begin{array}{c}-0.014 * * * \\
(0.003)\end{array}$ & $\begin{array}{c}-0.011 * * * \\
(0.002)\end{array}$ & $\begin{array}{c}-0.010 * * * \\
(0.003)\end{array}$ & $\begin{array}{c}-0.012 * * * \\
(0.002)\end{array}$ \\
\hline Sec. edu. level & $\begin{array}{c}-0.012 * * * \\
(0.003)\end{array}$ & $\begin{array}{l}-0.003 \\
(0.003)\end{array}$ & $\begin{array}{c}0.000 \\
(0.004)\end{array}$ & $\begin{array}{l}-0.002 \\
(0.003)\end{array}$ \\
\hline High edu. level & $\begin{array}{c}-0.052 * * * \\
(0.003)\end{array}$ & $\begin{array}{c}-0.014 * * * \\
(0.004)\end{array}$ & $\begin{array}{c}-0.008 \\
(0.005)\end{array}$ & $\begin{array}{c}-0.015 * * * \\
(0.004)\end{array}$ \\
\hline North-West & $\begin{array}{c}-0.021 * * * \\
(0.005)\end{array}$ & $\begin{array}{l}-0.007 \\
(0.005)\end{array}$ & $\begin{array}{c}-0.015^{* * * *} \\
(0.005)\end{array}$ & $\begin{array}{c}-0.005 \\
(0.005)\end{array}$ \\
\hline Central-Volga & $\begin{array}{c}-0.013 * * * \\
(0.003)\end{array}$ & $\begin{array}{c}-0.011 * * * \\
(0.003)\end{array}$ & $\begin{array}{c}-0.015^{* * *} \\
(0.004)\end{array}$ & $\begin{array}{c}-0.009 * * * \\
(0.003)\end{array}$ \\
\hline South & $\begin{array}{c}0.003 \\
(0.005)\end{array}$ & $\begin{array}{c}-0.005 \\
(0.004)\end{array}$ & $\begin{array}{c}-0.004 \\
(0.005)\end{array}$ & $\begin{array}{l}-0.003 \\
(0.004)\end{array}$ \\
\hline East & $\begin{array}{c}0.013 * * * \\
(0.004)\end{array}$ & $\begin{array}{c}0.010 * * * \\
(0.003)\end{array}$ & $\begin{array}{c}0.009 * * \\
(0.004)\end{array}$ & $\begin{array}{c}0.011 * * * \\
(0.003)\end{array}$ \\
\hline City & $\begin{array}{c}-0.014 * * * \\
(0.003)\end{array}$ & $\begin{array}{c}-0.010 * * * \\
(0.002)\end{array}$ & $\begin{array}{c}-0.010 * * * \\
(0.003)\end{array}$ & $\begin{array}{c}-0.011 * * * \\
(0.002)\end{array}$ \\
\hline Village & $\begin{array}{c}-0.041 * * * \\
(0.003)\end{array}$ & $\begin{array}{c}-0.029 * * * \\
(0.002)\end{array}$ & $\begin{array}{c}-0.030 * * * \\
(0.003)\end{array}$ & $\begin{array}{c}-0.032 * * * \\
(0.002)\end{array}$ \\
\hline Immigrant & & & $\begin{array}{c}0.016 * * * \\
(0.003)\end{array}$ & \\
\hline $\begin{array}{l}\text { Immigrant } \\
\text { Caucasus,CA }\end{array}$ & & & & $\begin{array}{c}0.066^{* * *} \\
(0.007)\end{array}$ \\
\hline $\begin{array}{l}\text { Immigrants not } \\
\text { CCA, not Russia }\end{array}$ & & & & $\begin{array}{c}0.029 * * * \\
(0.007)\end{array}$ \\
\hline Other immigrants & & & & $\begin{array}{c}0.007^{* * *} \\
(0.002)\end{array}$ \\
\hline y2003 & $\begin{array}{c}-0.008 \\
(0.005)\end{array}$ & & & \\
\hline y2005 & $\begin{array}{c}-0.001 \\
(0.006)\end{array}$ & $\begin{array}{c}-0.002 \\
(0.005)\end{array}$ & $\begin{array}{c}-0.005 \\
(0.015)\end{array}$ & $\begin{array}{l}-0.002 \\
(0.005)\end{array}$ \\
\hline y2006 & $\begin{array}{c}0.008 \\
(0.005)\end{array}$ & $\begin{array}{c}0.010 * * \\
(0.005)\end{array}$ & $\begin{array}{c}0.005 \\
(0.011)\end{array}$ & $\begin{array}{c}0.011^{* *} \\
(0.005)\end{array}$ \\
\hline y2007 & $\begin{array}{c}0.001 \\
(0.005)\end{array}$ & $\begin{array}{c}0.001 \\
(0.005)\end{array}$ & $\begin{array}{c}0.015 \\
(0.015)\end{array}$ & $\begin{array}{c}0.002 \\
(0.005)\end{array}$ \\
\hline y2008 & $\begin{array}{l}-0.001 \\
(0.005)\end{array}$ & $\begin{array}{c}0.001 \\
(0.005)\end{array}$ & $\begin{array}{c}0.002 \\
(0.009)\end{array}$ & $\begin{array}{c}0.001 \\
(0.005)\end{array}$ \\
\hline y2009 & $\begin{array}{l}0.010 * \\
(0.006)\end{array}$ & $\begin{array}{l}0.008 * \\
(0.005)\end{array}$ & $\begin{array}{c}0.010 \\
(0.010)\end{array}$ & $\begin{array}{l}0.008 * \\
(0.005)\end{array}$ \\
\hline y2010 & $\begin{array}{c}0.004 \\
(0.005)\end{array}$ & $\begin{array}{c}0.004 \\
(0.004)\end{array}$ & $\begin{array}{c}0.005 \\
(0.009)\end{array}$ & $\begin{array}{c}0.004 \\
(0.004)\end{array}$ \\
\hline y2011 & $\begin{array}{c}0.003 \\
(0.005)\end{array}$ & $\begin{array}{c}0.003 \\
(0.004)\end{array}$ & $\begin{array}{c}0.004 \\
(0.009)\end{array}$ & $\begin{array}{c}0.003 \\
(0.004)\end{array}$ \\
\hline Machine building & & $\begin{array}{c}-0.045^{* * *} \\
(0.004)\end{array}$ & $\begin{array}{c}-0.044^{* * *} \\
(0.005)\end{array}$ & $\begin{array}{c}-0.044 * * * \\
(0.004)\end{array}$ \\
\hline Military & & $\begin{array}{c}-0.061 * * * \\
(0.003)\end{array}$ & $\begin{array}{c}-0.058 * * * \\
(0.004)\end{array}$ & $\begin{array}{c}-0.060 * * * \\
(0.003)\end{array}$ \\
\hline Gas and oil ind. & & $\begin{array}{c}-0.058 * * * \\
(0.003)\end{array}$ & $\begin{array}{c}-0.059 * * * \\
(0.003)\end{array}$ & $\begin{array}{c}-0.057 * * * \\
(0.003)\end{array}$ \\
\hline
\end{tabular}




\begin{tabular}{|c|c|c|c|c|}
\hline & & (2) & (3) & (4) \\
\hline \multirow[t]{2}{*}{ Other heavy ind. } & & $-0.048 * * *$ & $-0.051 * * *$ & $-0.048 * * *$ \\
\hline & & $(0.003)$ & $(0.004)$ & $(0.003)$ \\
\hline \multirow[t]{2}{*}{ Construction } & & $0.045^{* * *}$ & $0.032 * * *$ & $0.043 * * *$ \\
\hline & & $(0.006)$ & $(0.008)$ & $(0.006)$ \\
\hline \multirow{2}{*}{$\begin{array}{l}\text { Transport, } \\
\text { communication }\end{array}$} & & 0.001 & -0.004 & 0.001 \\
\hline & & $(0.005)$ & $(0.006)$ & $(0.005)$ \\
\hline \multirow[t]{2}{*}{ Agriculture } & & $-0.024 * * *$ & $-0.028 * * *$ & $-0.022 * * *$ \\
\hline & & $(0.005)$ & $(0.006)$ & $(0.005)$ \\
\hline \multirow{2}{*}{$\begin{array}{l}\text { Public } \\
\text { administration }\end{array}$} & & $-0.051 * * *$ & $-0.048 * * *$ & $-0.050 * * *$ \\
\hline & & $(0.004)$ & $(0.006)$ & $(0.004)$ \\
\hline \multirow[t]{2}{*}{ Education } & & $-0.045 * * *$ & $-0.047 * * *$ & $-0.044 * * *$ \\
\hline & & $(0.004)$ & $(0.004)$ & $(0.004)$ \\
\hline \multirow[t]{2}{*}{ Science and culture } & & -0.005 & -0.008 & -0.004 \\
\hline & & $(0.007)$ & $(0.008)$ & $(0.007)$ \\
\hline \multirow[t]{2}{*}{ Health } & & $-0.043 * * *$ & $-0.046 * * *$ & $-0.042 * * *$ \\
\hline & & $(0.004)$ & $(0.004)$ & $(0.004)$ \\
\hline \multirow{2}{*}{ Defence } & & $-0.051 * * *$ & $-0.057 * * *$ & $-0.051 * * *$ \\
\hline & & $(0.003)$ & $(0.003)$ & $(0.003)$ \\
\hline \multirow{2}{*}{$\begin{array}{l}\text { Trade, related } \\
\text { services }\end{array}$} & & $0.073^{* * *}$ & $0.064 * * *$ & $0.073 * * *$ \\
\hline & & $(0.006)$ & $(0.008)$ & $(0.006)$ \\
\hline \multirow[t]{2}{*}{ Finance } & & $-0.029 * * *$ & $-0.028 * * *$ & $-0.029 * * *$ \\
\hline & & $(0.006)$ & $(0.008)$ & $(0.006)$ \\
\hline \multirow[t]{2}{*}{ Energy ind. } & & $-0.055^{* * *}$ & $-0.059 * * *$ & $-0.055 * * *$ \\
\hline & & $(0.004)$ & $(0.004)$ & $(0.004)$ \\
\hline \multirow[t]{2}{*}{ Housing } & & $-0.033 * * *$ & $-0.035 * * *$ & $-0.032 * * *$ \\
\hline & & $(0.004)$ & $(0.005)$ & $(0.004)$ \\
\hline \multirow[t]{2}{*}{ Other ind. } & & $0.045^{* * *}$ & $0.040 * * *$ & $0.042 * * *$ \\
\hline & & $(0.010)$ & $(0.013)$ & $(0.010)$ \\
\hline \multirow{2}{*}{$\begin{array}{l}\text { Legislators, senior } \\
\text { managers, officials }\end{array}$} & & $0.036^{* * *}$ & 0.002 & $0.035 * * *$ \\
\hline & & $(0.006)$ & $(0.006)$ & $(0.006)$ \\
\hline \multirow[t]{2}{*}{ Professionals } & & $-0.046 * * *$ & $-0.053 * * *$ & $-0.045^{* * *}$ \\
\hline & & $(0.003)$ & $(0.004)$ & $(0.003)$ \\
\hline \multirow{2}{*}{$\begin{array}{l}\text { Assoc. Profess. } \\
\text { with sec. spec. ed. }\end{array}$} & & $-0.049 * * *$ & $-0.053 * * *$ & $-0.048 * * *$ \\
\hline & & $(0.003)$ & $(0.003)$ & $(0.003)$ \\
\hline \multirow[t]{2}{*}{ Clerks } & & $-0.055 * * *$ & $-0.056 * * *$ & $-0.055 * * *$ \\
\hline & & $(0.002)$ & $(0.003)$ & $(0.002)$ \\
\hline \multirow[t]{2}{*}{ Service workers } & & $-0.008 * *$ & $-0.010^{* *}$ & $-0.008 * *$ \\
\hline & & $(0.004)$ & $(0.005)$ & $(0.004)$ \\
\hline \multirow{2}{*}{$\begin{array}{l}\text { Skilled agricultural } \\
\text { and fishery workers }\end{array}$} & & $0.108^{* * *}$ & $0.155^{* * *}$ & $0.112^{* * *}$ \\
\hline & & $(0.025)$ & $(0.037)$ & $(0.025)$ \\
\hline \multirow{2}{*}{$\begin{array}{l}\text { Craft and related } \\
\text { trades }\end{array}$} & & $-0.008^{* *}$ & $-0.009 * *$ & $-0.008 * *$ \\
\hline & & $(0.004)$ & $(0.004)$ & $(0.004)$ \\
\hline \multirow{2}{*}{$\begin{array}{l}\text { Plant /Machine } \\
\text { operators/Ind. w-s }\end{array}$} & & $-0.028 * * *$ & $-0.028 * * *$ & $-0.026 * * *$ \\
\hline & & $(0.003)$ & $(0.004)$ & $(0.003)$ \\
\hline Observations & 61965 & 56100 & 35374 & 55493 \\
\hline
\end{tabular}

Notes: Robust standard errors in parentheses. * significant at 10\%; ** significant at 5\%; *** significant at $1 \%$.

Reference categories are: female, not married, primary edu. level, Moscow/St. Petersburg, large regional center, nonimmigrants, year 2004, Light and food industry, Unskilled workers. 
Table A4: Determinants of informal employment - Informal employees and those working not in enterprise/organization, main and secondary jobs: marginal effects

\begin{tabular}{|c|c|c|c|c|}
\hline & $\begin{array}{c}(1) \\
\text { Probit }\end{array}$ & $\begin{array}{c}(2) \\
\text { Probit }\end{array}$ & $\begin{array}{c}\text { (3) } \\
\text { Probit }\end{array}$ & $\begin{array}{c}(4) \\
\text { Probit }\end{array}$ \\
\hline Age & $\begin{array}{c}-0.002^{* * *} \\
(0.000)\end{array}$ & $\begin{array}{c}-0.001 * * * \\
(0.000)\end{array}$ & $\begin{array}{c}-0.001^{* * *} \\
(0.000)\end{array}$ & $\begin{array}{c}-0.001^{* * *} \\
(0.000)\end{array}$ \\
\hline Male & $\begin{array}{c}0.038 * * * \\
(0.003)\end{array}$ & $\begin{array}{c}0.035^{* * * *} \\
(0.004)\end{array}$ & $\begin{array}{c}0.036 * * * \\
(0.005)\end{array}$ & $\begin{array}{c}0.033^{* * *} \\
(0.004)\end{array}$ \\
\hline Married & $\begin{array}{c}-0.029 * * * \\
(0.003)\end{array}$ & $\begin{array}{c}-0.024^{* * *} \\
(0.003)\end{array}$ & $\begin{array}{c}-0.024 * * * \\
(0.004)\end{array}$ & $\begin{array}{c}-0.025^{* * *} \\
(0.003)\end{array}$ \\
\hline Sec. edu. & $\begin{array}{c}-0.026 * * * \\
(0.004)\end{array}$ & $\begin{array}{c}-0.009 * * \\
(0.004)\end{array}$ & $\begin{array}{c}-0.008 \\
(0.005)\end{array}$ & $\begin{array}{c}-0.008 * * \\
(0.004)\end{array}$ \\
\hline Higher edu. & $\begin{array}{c}-0.098 * * * \\
(0.004)\end{array}$ & $\begin{array}{c}-0.027 * * * \\
(0.005)\end{array}$ & $\begin{array}{c}-0.020 * * * \\
(0.007)\end{array}$ & $\begin{array}{c}-0.028 * * * \\
(0.005)\end{array}$ \\
\hline North-West & $\begin{array}{c}0.005 \\
(0.007)\end{array}$ & $\begin{array}{c}0.027 * * * \\
(0.008)\end{array}$ & $\begin{array}{c}0.024^{* *} \\
(0.010)\end{array}$ & $\begin{array}{c}0.028 * * * \\
(0.008)\end{array}$ \\
\hline Central-Volga & $\begin{array}{c}0.022^{* * *} \\
(0.005)\end{array}$ & $\begin{array}{c}0.023^{* * *} \\
(0.005)\end{array}$ & $\begin{array}{c}0.027 * * * \\
(0.006)\end{array}$ & $\begin{array}{c}0.028^{* * *} \\
(0.005)\end{array}$ \\
\hline South & $\begin{array}{c}0.068 * * * \\
(0.007)\end{array}$ & $\begin{array}{c}0.054^{* * *} \\
(0.007)\end{array}$ & $\begin{array}{c}0.068 * * * \\
(0.008)\end{array}$ & $\begin{array}{c}0.057 * * * \\
(0.007)\end{array}$ \\
\hline East & $\begin{array}{c}0.047 * * * \\
(0.005)\end{array}$ & $\begin{array}{c}0.043 * * * \\
(0.005)\end{array}$ & $\begin{array}{c}0.049 * * * \\
(0.007)\end{array}$ & $\begin{array}{c}0.046 * * * \\
(0.005)\end{array}$ \\
\hline City & $\begin{array}{c}-0.008^{* *} \\
(0.004)\end{array}$ & $\begin{array}{l}-0.003 \\
(0.004)\end{array}$ & $\begin{array}{l}-0.008^{*} \\
(0.004)\end{array}$ & $\begin{array}{l}-0.005 \\
(0.004)\end{array}$ \\
\hline Village & $\begin{array}{c}-0.029 * * * \\
(0.004)\end{array}$ & $\begin{array}{c}-0.013^{* * *} \\
(0.004)\end{array}$ & $\begin{array}{l}-0.009 * \\
(0.005)\end{array}$ & $\begin{array}{c}-0.017^{* * *} \\
(0.004)\end{array}$ \\
\hline Immigrant & & & $\begin{array}{c}0.015^{* * *} \\
(0.004)\end{array}$ & \\
\hline $\begin{array}{l}\text { Immigrant } \\
\text { Caucasus,CA }\end{array}$ & & & & $0.091^{* * *}$ \\
\hline $\begin{array}{l}\text { Immigrants not } \\
\text { CCA, not Russia } \\
\text { Other immigrants }\end{array}$ & & & & $\begin{array}{c}(0.008) \\
0.062 * * * \\
(0.010) \\
0.004 \\
(0.003)\end{array}$ \\
\hline y2003 & $\begin{array}{c}-0.021^{* * *} \\
(0.007)\end{array}$ & & & \\
\hline y2005 & $\begin{array}{l}-0.008 \\
(0.007)\end{array}$ & $\begin{array}{c}-0.014^{* *} \\
(0.006)\end{array}$ & $\begin{array}{l}-0.026 \\
(0.018)\end{array}$ & $\begin{array}{c}-0.014^{* *} \\
(0.006)\end{array}$ \\
\hline y2006 & $\begin{array}{c}0.007 \\
(0.007)\end{array}$ & $\begin{array}{c}0.010 \\
(0.006)\end{array}$ & $\begin{array}{l}-0.003 \\
(0.014)\end{array}$ & $\begin{array}{c}0.010 \\
(0.006)\end{array}$ \\
\hline y2007 & $\begin{array}{c}0.004 \\
(0.007)\end{array}$ & $\begin{array}{c}0.002 \\
(0.006)\end{array}$ & $\begin{array}{c}0.023 \\
(0.019)\end{array}$ & $\begin{array}{c}0.003 \\
(0.006)\end{array}$ \\
\hline y2008 & $\begin{array}{l}-0.007 \\
(0.007)\end{array}$ & $\begin{array}{l}-0.007 \\
(0.006)\end{array}$ & $\begin{array}{l}-0.020^{*} \\
(0.012)\end{array}$ & $\begin{array}{l}-0.007 \\
(0.006)\end{array}$ \\
\hline y2009 & $\begin{array}{c}0.019 * * * \\
(0.007)\end{array}$ & $\begin{array}{l}0.012^{*} \\
(0.006)\end{array}$ & $\begin{array}{l}-0.002 \\
(0.013)\end{array}$ & $\begin{array}{l}0.012^{*} \\
(0.006)\end{array}$ \\
\hline y2010 & $\begin{array}{l}0.012 * \\
(0.006)\end{array}$ & $\begin{array}{c}0.007 \\
(0.006)\end{array}$ & $\begin{array}{l}-0.007 \\
(0.012)\end{array}$ & $\begin{array}{c}0.007 \\
(0.006)\end{array}$ \\
\hline y2011 & $\begin{array}{l}0.016 * * \\
(0.006)\end{array}$ & $\begin{array}{c}0.009 \\
(0.006)\end{array}$ & $\begin{array}{l}-0.004 \\
(0.012)\end{array}$ & $\begin{array}{l}0.010^{*} \\
(0.006)\end{array}$ \\
\hline Machine building & & $\begin{array}{c}-0.079 * * * \\
(0.006)\end{array}$ & $\begin{array}{c}-0.076^{* * * *} \\
(0.008)\end{array}$ & $\begin{array}{c}-0.078 * * * \\
(0.006)\end{array}$ \\
\hline Military & & $\begin{array}{c}-0.097 * * * \\
(0.006)\end{array}$ & $\begin{array}{c}-0.104^{* * * *} \\
(0.007)\end{array}$ & $\begin{array}{c}-0.098 * * * \\
(0.006)\end{array}$ \\
\hline Gas and oil ind. & & $\begin{array}{c}-0.077^{* * *} \\
(0.006) \\
(2)\end{array}$ & $\begin{array}{c}-0.078 * * * \\
(0.008) \\
(3)\end{array}$ & $\begin{array}{c}-0.076 * * * \\
(0.006) \\
(4)\end{array}$ \\
\hline Other heavy ind. & & $-0.071 * * *$ & $-0.070 * * *$ & $-0.071 * * *$ \\
\hline
\end{tabular}




\begin{tabular}{|c|c|c|c|c|}
\hline & & $(0.006)$ & $(0.008)$ & $(0.006)$ \\
\hline Construction & & $\begin{array}{c}0.112 * * * \\
(0.009)\end{array}$ & $\begin{array}{c}0.103 * * * \\
(0.012)\end{array}$ & $\begin{array}{c}0.110 * * * \\
(0.009)\end{array}$ \\
\hline Transport, & & $0.019 * * *$ & $0.021^{* *}$ & $0.019 * *$ \\
\hline Communication & & $(0.007)$ & $(0.009)$ & $(0.007)$ \\
\hline Agriculture & & $\begin{array}{c}-0.024 * * * \\
(0.007)\end{array}$ & $\begin{array}{c}-0.029 * * * \\
(0.009)\end{array}$ & $\begin{array}{c}-0.021^{* * *} \\
(0.007)\end{array}$ \\
\hline Public & & $-0.069 * * *$ & $-0.069 * * *$ & $-0.067 * * *$ \\
\hline Administration & & $(0.008)$ & $(0.010)$ & $(0.008)$ \\
\hline Education & & $\begin{array}{c}-0.058^{* * *} \\
(0.006)\end{array}$ & $\begin{array}{c}-0.069 * * * \\
(0.007)\end{array}$ & $\begin{array}{c}-0.058 * * * \\
(0.006)\end{array}$ \\
\hline Science and culture & & $\begin{array}{c}0.002 \\
(0.011)\end{array}$ & $\begin{array}{c}0.001 \\
(0.013)\end{array}$ & $\begin{array}{c}0.002 \\
(0.011)\end{array}$ \\
\hline Health & & $\begin{array}{c}-0.070 * * * \\
(0.006)\end{array}$ & $\begin{array}{c}-0.078 * * * \\
(0.007)\end{array}$ & $\begin{array}{c}-0.070 * * * \\
(0.006)\end{array}$ \\
\hline Defence & & $\begin{array}{c}-0.094 * * * \\
(0.004)\end{array}$ & $\begin{array}{c}-0.098^{* * *} \\
(0.005)\end{array}$ & $\begin{array}{c}-0.094 * * * \\
(0.004)\end{array}$ \\
\hline Trade, related & & $0.158 * * *$ & $0.150 * * *$ & $0.158 * * *$ \\
\hline Services & & $(0.009)$ & $(0.011)$ & $(0.009)$ \\
\hline Finance & & $\begin{array}{c}-0.042 * * * \\
(0.010)\end{array}$ & $\begin{array}{c}-0.036 * * * \\
(0.013)\end{array}$ & $\begin{array}{c}-0.043 * * * \\
(0.010)\end{array}$ \\
\hline Energy ind. & & $\begin{array}{c}-0.084 * * * \\
(0.007)\end{array}$ & $\begin{array}{c}-0.087 * * * \\
(0.009)\end{array}$ & $\begin{array}{c}-0.083^{* * *} \\
(0.007)\end{array}$ \\
\hline Housing & & $\begin{array}{c}-0.035 * * * \\
(0.008)\end{array}$ & $\begin{array}{c}-0.038^{* * *} \\
(0.009)\end{array}$ & $\begin{array}{c}-0.033^{* * *} \\
(0.008)\end{array}$ \\
\hline Other ind. & & $\begin{array}{c}0.175^{* * *} \\
(0.015)\end{array}$ & $\begin{array}{c}0.166^{* * *} \\
(0.021)\end{array}$ & $\begin{array}{c}0.173 * * * \\
(0.016)\end{array}$ \\
\hline $\begin{array}{l}\text { Legislators, senior } \\
\text { managers, officials }\end{array}$ & & $\begin{array}{l}-0.004 \\
(0.007)\end{array}$ & $\begin{array}{c}-0.039 * * * \\
(0.007)\end{array}$ & $\begin{array}{l}-0.006 \\
(0.007)\end{array}$ \\
\hline Professionals & & $\begin{array}{c}-0.080^{* * *} \\
(0.005)\end{array}$ & $\begin{array}{c}-0.089 * * * \\
(0.006)\end{array}$ & $\begin{array}{c}-0.080 * * * \\
(0.005)\end{array}$ \\
\hline $\begin{array}{l}\text { Assoc. Profess. } \\
\text { with sec. spec. ed. }\end{array}$ & & $\begin{array}{c}-0.089 * * * \\
(0.004)\end{array}$ & $\begin{array}{c}-0.098 * * * \\
(0.005)\end{array}$ & $\begin{array}{c}-0.088 * * * \\
(0.004)\end{array}$ \\
\hline Clerks & & $\begin{array}{c}-0.093 * * * \\
(0.004)\end{array}$ & $\begin{array}{c}-0.098 * * * \\
(0.005)\end{array}$ & $\begin{array}{c}-0.092^{* * *} \\
(0.004)\end{array}$ \\
\hline Service workers & & $\begin{array}{c}0.018 * * * \\
(0.006)\end{array}$ & $\begin{array}{c}0.005 \\
(0.007)\end{array}$ & $\begin{array}{c}0.017 * * * \\
(0.006)\end{array}$ \\
\hline $\begin{array}{l}\text { Skilled agricultural } \\
\text { and fishery workers }\end{array}$ & & $\begin{array}{c}0.087 * * * \\
(0.027)\end{array}$ & $\begin{array}{c}0.139 * * * \\
(0.040)\end{array}$ & $\begin{array}{c}0.091 * * * \\
(0.027)\end{array}$ \\
\hline Craft and related & & $-0.015^{* * *}$ & $-0.013^{* *}$ & $-0.014 * * *$ \\
\hline Trades & & $(0.005)$ & $(0.006)$ & $(0.005)$ \\
\hline $\begin{array}{l}\text { Plant /Machine } \\
\text { operators/Ind. W-s }\end{array}$ & & $\begin{array}{c}-0.046 * * * \\
(0.004)\end{array}$ & $\begin{array}{c}-0.048^{* * *} \\
(0.005)\end{array}$ & $\begin{array}{c}-0.044 * * * \\
(0.004)\end{array}$ \\
\hline Observations & 61965 & 56100 & 35374 & 55493 \\
\hline
\end{tabular}

Notes: Robust standard errors in parentheses. * significant at 10\%; ** significant at 5\%; *** significant at $1 \%$.

Reference categories are: female, not married, primary edu. level, Moscow/St. Petersburg, large regional center, nonimmigrants, year 2004, Light and food industry, Unskilled workers. 
Table A5: Determinants of informal employment - absence of three mandatory benefits, main and secondary jobs: marginal effects

\begin{tabular}{|c|c|c|c|c|}
\hline & $\begin{array}{l}(1) \\
\text { informbenall, } \\
\text { Probit }\end{array}$ & $\begin{array}{l}(2) \\
\text { informbenall, } \\
\text { Probit }\end{array}$ & $\begin{array}{l}(3) \\
\text { informbenall, } \\
\text { Probit }\end{array}$ & $\begin{array}{l}(4) \\
\text { informbenall, } \\
\text { Probit }\end{array}$ \\
\hline \multirow[t]{2}{*}{ Age } & $-0.002 * * *$ & $-0.001^{* * *}$ & $-0.001 * * *$ & $-0.001^{* * *}$ \\
\hline & $(0.000)$ & $(0.000)$ & $(0.000)$ & $(0.000)$ \\
\hline \multirow{2}{*}{ Male } & $0.028 * * *$ & $0.025 * * *$ & $0.028 * * *$ & $0.025 * * *$ \\
\hline & $(0.003)$ & $(0.003)$ & $(0.004)$ & $(0.003)$ \\
\hline \multirow[t]{2}{*}{ Married } & $-0.022 * * *$ & $-0.017 * * *$ & $-0.020 * * *$ & $-0.018 * * *$ \\
\hline & $(0.003)$ & $(0.003)$ & $(0.004)$ & $(0.003)$ \\
\hline \multirow[t]{2}{*}{ Sec. edu. } & $-0.015 * * *$ & -0.001 & 0.000 & -0.001 \\
\hline & $(0.004)$ & $(0.004)$ & $(0.005)$ & $(0.004)$ \\
\hline \multirow[t]{2}{*}{ High edu. } & $-0.061 * * *$ & $-0.010 * *$ & -0.007 & $-0.011 * *$ \\
\hline & $(0.004)$ & $(0.005)$ & $(0.007)$ & $(0.005)$ \\
\hline \multirow[t]{2}{*}{ North-west } & $-0.043 * * *$ & $-0.020 * * *$ & $-0.021 * * *$ & $-0.019 * * *$ \\
\hline & $(0.004)$ & $(0.005)$ & $(0.007)$ & $(0.005)$ \\
\hline \multirow[t]{2}{*}{ Central-Volga } & $-0.052 * * *$ & $-0.037 * * *$ & $-0.035 * * *$ & $-0.035 * * *$ \\
\hline & $(0.004)$ & $(0.003)$ & $(0.005)$ & $(0.003)$ \\
\hline \multirow[t]{2}{*}{ South } & $-0.027 * * *$ & $-0.022 * * *$ & $-0.020 * * *$ & $-0.021 * * *$ \\
\hline & $(0.005)$ & $(0.004)$ & $(0.005)$ & $(0.004)$ \\
\hline \multirow[t]{2}{*}{ East } & $-0.026 * * *$ & $-0.015 * * *$ & $-0.010 * *$ & $-0.015^{* * *}$ \\
\hline & $(0.004)$ & $(0.004)$ & $(0.005)$ & $(0.004)$ \\
\hline \multirow[t]{2}{*}{ City } & $-0.032 * * *$ & $-0.020 * * *$ & $-0.019 * * *$ & $-0.021 * * *$ \\
\hline & $(0.003)$ & $(0.003)$ & $(0.004)$ & $(0.003)$ \\
\hline \multirow[t]{2}{*}{ Village } & $-0.058 * * *$ & $-0.041 * * *$ & $-0.037 * * *$ & $-0.043 * * *$ \\
\hline & $(0.003)$ & $(0.003)$ & $(0.004)$ & $(0.003)$ \\
\hline \multirow[t]{2}{*}{ y2003 } & $-0.018 * * *$ & & & \\
\hline & $(0.005)$ & & & \\
\hline \multirow[t]{2}{*}{ y2005 } & $-0.011^{*}$ & $-0.014 * * *$ & $-0.036 * * *$ & $-0.012 * *$ \\
\hline & $(0.006)$ & $(0.005)$ & $(0.011)$ & $(0.005)$ \\
\hline \multirow[t]{2}{*}{ y2006 } & -0.008 & -0.008 & $-0.030 * * *$ & -0.007 \\
\hline & $(0.005)$ & $(0.005)$ & $(0.008)$ & $(0.005)$ \\
\hline \multirow[t]{2}{*}{ y2007 } & $-0.025 * * *$ & $-0.024 * * *$ & $-0.022 * *$ & $-0.024 * * *$ \\
\hline & $(0.005)$ & $(0.004)$ & $(0.010)$ & $(0.004)$ \\
\hline \multirow[t]{2}{*}{ y2008 } & $-0.022 * * *$ & $-0.022 * * *$ & $-0.040 * * *$ & $-0.021 * * *$ \\
\hline & $(0.005)$ & $(0.004)$ & $(0.008)$ & $(0.004)$ \\
\hline \multirow[t]{2}{*}{ y2009 } & $-0.016 * * *$ & $-0.020 * * *$ & $-0.038 * * *$ & $-0.019 * * *$ \\
\hline & $(0.005)$ & $(0.004)$ & $(0.008)$ & $(0.004)$ \\
\hline \multirow[t]{2}{*}{ y2010 } & $-0.016 * * *$ & $-0.020 * * *$ & $-0.039 * * *$ & $-0.019 * * *$ \\
\hline & $(0.005)$ & $(0.004)$ & $(0.008)$ & $(0.004)$ \\
\hline Immigrant & & & $\begin{array}{l}0.008 * * \\
(0.004)\end{array}$ & \\
\hline \multicolumn{2}{|l|}{ Immigrant } & & & $0.051 * * *$ \\
\hline Caucasus,CA & & & & $(0.008)$ \\
\hline Immigrants not & & & & $0.028 * * *$ \\
\hline CCA, not Russia & & & & $(0.008)$ \\
\hline Other immigrants & & & & 0.003 \\
\hline & & & & $(0.003)$ \\
\hline Machine building & & $-0.053 * * *$ & $-0.053 * * *$ & $-0.052 * * *$ \\
\hline & & $(0.005)$ & $(0.006)$ & $(0.005)$ \\
\hline Military & & $-0.072 * * *$ & $-0.069 * * *$ & $-0.071^{* * *}$ \\
\hline & & $(0.004)$ & $(0.005)$ & $(0.004)$ \\
\hline Gas and oil ind. & & $-0.047 * * *$ & $-0.051 * * *$ & $-0.047 * * *$ \\
\hline & & $(0.006)$ & $(0.007)$ & $(0.006)$ \\
\hline Other heavy ind & & $-0.054 * * *$ & $-0.054 * * *$ & $-0.054 * * *$ \\
\hline & & $(0.004)$ & $(0.006)$ & $(0.004)$ \\
\hline Construction & & $0.052^{* * *}$ & $0.041^{* * *}$ & $0.050 * * *$ \\
\hline & & $(0.008)$ & $(0.010)$ & $(0.008)$ \\
\hline
\end{tabular}




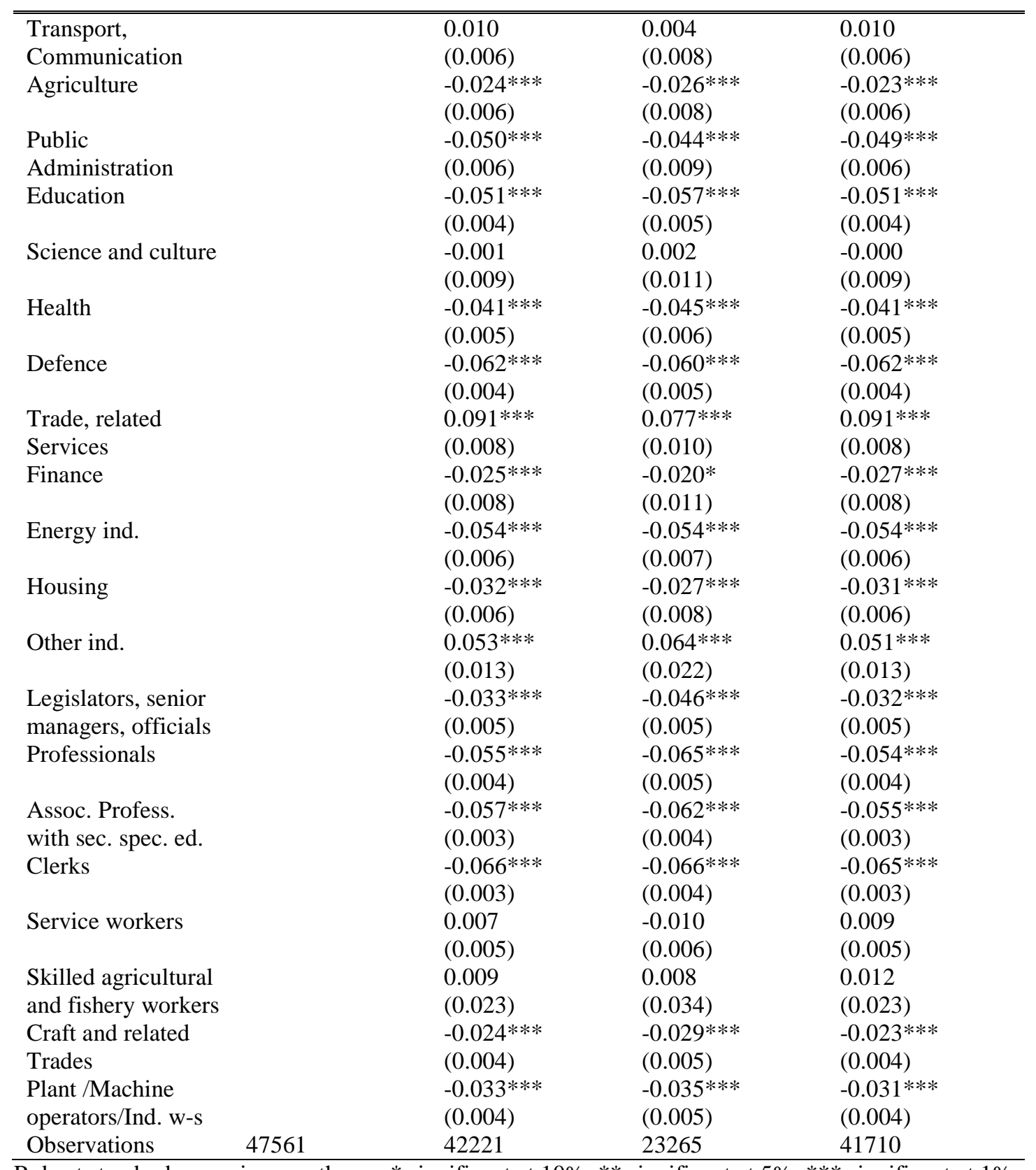

Notes: Robust standard errors in parentheses. * significant at 10\%; ** significant at 5\%; *** significant at $1 \%$. Reference categories are: female, not married, primary education level, Moscow/St. Petersburg, large regional center, non-immigrants, year 2004, Light and food industry, Unskilled workers. 
Table A6 Determinants of informal employment - firm size $<5$ employees: marginal effects.

\begin{tabular}{|c|c|c|c|c|}
\hline & (1) & (2) & (3) & (4) \\
\hline & Probit & Probit & Probit & Probit \\
\hline \multirow{2}{*}{ Age } & $-0.001 * * *$ & $0.000 * *$ & $0.000 * * *$ & $0.000 * *$ \\
\hline & $(0.000)$ & $(0.000)$ & $(0.000)$ & $(0.000)$ \\
\hline \multirow[t]{2}{*}{ Male } & $-0.032 * * *$ & $-0.009 * * *$ & $-0.008 * *$ & $-0.009 * * *$ \\
\hline & $(0.003)$ & $(0.003)$ & $(0.003)$ & $(0.003)$ \\
\hline \multirow[t]{2}{*}{ Married } & -0.001 & 0.001 & -0.000 & 0.001 \\
\hline & $(0.003)$ & $(0.002)$ & $(0.003)$ & $(0.002)$ \\
\hline \multirow[t]{2}{*}{ Sec. edu. level } & $-0.010 * *$ & $-0.009 * *$ & $-0.013^{* * *}$ & $-0.008 * *$ \\
\hline & $(0.004)$ & $(0.003)$ & $(0.005)$ & $(0.003)$ \\
\hline \multirow[t]{2}{*}{ High edu. level } & $-0.038 * * *$ & $-0.016^{* * *}$ & $-0.021 * * *$ & $-0.016 * * *$ \\
\hline & $(0.004)$ & $(0.004)$ & $(0.005)$ & $(0.004)$ \\
\hline \multirow[t]{2}{*}{ North-West } & $-0.010 *$ & 0.003 & 0.003 & 0.003 \\
\hline & $(0.006)$ & $(0.006)$ & $(0.007)$ & $(0.006)$ \\
\hline \multirow[t]{2}{*}{ Central-Volga } & $0.016^{* * *}$ & $0.023 * * *$ & $0.023 * * *$ & $0.022 * * *$ \\
\hline & $(0.004)$ & $(0.004)$ & $(0.005)$ & $(0.004)$ \\
\hline \multirow[t]{2}{*}{ South } & $0.029 * * *$ & $0.029 * * *$ & $0.028 * * *$ & $0.029 * * *$ \\
\hline & $(0.006)$ & $(0.005)$ & $(0.006)$ & $(0.005)$ \\
\hline \multirow[t]{2}{*}{ East } & $0.018 * * *$ & $0.023 * * *$ & $0.016 * * *$ & $0.022 * * *$ \\
\hline & $(0.005)$ & $(0.004)$ & $(0.005)$ & $(0.004)$ \\
\hline \multirow[t]{2}{*}{ City } & $-0.008 * *$ & 0.004 & 0.001 & 0.004 \\
\hline & $(0.003)$ & $(0.003)$ & $(0.004)$ & $(0.003)$ \\
\hline \multirow[t]{2}{*}{ Village } & $0.044^{* * *}$ & $0.054 * * *$ & $0.055 * * *$ & $0.055^{* * *}$ \\
\hline & $(0.004)$ & $(0.004)$ & $(0.005)$ & $(0.004)$ \\
\hline \multirow{2}{*}{ Immigrant } & & & 0.001 & \\
\hline & & & $(0.003)$ & \\
\hline Immigrant & & & & -0.003 \\
\hline \multirow{2}{*}{ Caucasus,CA } & & & & \\
\hline & & & & $(0.005)$ \\
\hline \multirow{3}{*}{$\begin{array}{l}\text { Immigrants not } \\
\text { CCA, not Russia }\end{array}$} & & & & 0.010 \\
\hline & & & & \\
\hline & & & & $(0.007)$ \\
\hline \multirow{2}{*}{ Other immigrants } & & & & $-0.004^{*}$ \\
\hline & & & & $(0.002)$ \\
\hline \multirow[t]{2}{*}{ y2003 } & -0.000 & & & \\
\hline & $(0.006)$ & & & \\
\hline \multirow[t]{2}{*}{ y2005 } & 0.006 & 0.002 & 0.007 & 0.001 \\
\hline & $(0.006)$ & $(0.005)$ & $(0.020)$ & $(0.005)$ \\
\hline \multirow[t]{2}{*}{ y2006 } & $0.011^{*}$ & $0.010^{*}$ & 0.017 & $0.010^{*}$ \\
\hline & $(0.006)$ & $(0.005)$ & $(0.015)$ & $(0.005)$ \\
\hline y2007 & 0.000 & -0.001 & 0.016 & -0.002 \\
\hline & $(0.006)$ & $(0.005)$ & (0.019) & $(0.005)$ \\
\hline y2008 & 0.000 & -0.001 & -0.001 & -0.001 \\
\hline & $(0.006)$ & $(0.005)$ & $(0.011)$ & $(0.005)$ \\
\hline y2009 & 0.002 & -0.003 & -0.003 & -0.003 \\
\hline & $(0.006)$ & $(0.005)$ & $(0.011)$ & $(0.005)$ \\
\hline y2010 & $0.018 * * *$ & $0.009 *$ & 0.009 & $0.009 *$ \\
\hline & $(0.006)$ & $(0.005)$ & $(0.012)$ & $(0.005)$ \\
\hline y2011 & $0.018 * * *$ & 0.008 & 0.008 & 0.007 \\
\hline & $(0.006)$ & $(0.005)$ & $(0.011)$ & $(0.005)$ \\
\hline Machine building & & $-0.024 * * *$ & $-0.023^{* *}$ & $-0.024 * * *$ \\
\hline & & $(0.007)$ & $(0.010)$ & $(0.007)$ \\
\hline Military & & $-0.028 * * *$ & -0.014 & $-0.028 * * *$ \\
\hline & & $(0.009)$ & $(0.015)$ & $(0.009)$ \\
\hline Gas and oil ind. & & -0.001 & -0.001 & -0.001 \\
\hline & & $(0.010)$ & $(0.013)$ & $(0.010)$ \\
\hline Other heavy ind. & & $-0.033^{* * *}$ & $-0.025^{* * *}$ & $-0.033 * * *$ \\
\hline & & $(0.005)$ & $(0.009)$ & $(0.005)$ \\
\hline
\end{tabular}




\begin{tabular}{|c|c|c|c|c|}
\hline & & (2) & (3) & (4) \\
\hline \multirow[t]{2}{*}{ Construction } & & $0.022 * * *$ & $0.028 * *$ & $0.022 * * *$ \\
\hline & & $(0.008)$ & $(0.011)$ & $(0.008)$ \\
\hline \multirow{2}{*}{$\begin{array}{l}\text { Transport, } \\
\text { communication }\end{array}$} & & $0.054 * * *$ & $0.065^{* * *}$ & $0.055^{* * *}$ \\
\hline & & $(0.010)$ & $(0.014)$ & $(0.010)$ \\
\hline \multirow[t]{2}{*}{ Agriculture } & & $0.020 * *$ & $0.029 * *$ & $0.021 * *$ \\
\hline & & $(0.009)$ & $(0.012)$ & $(0.009)$ \\
\hline \multirow{2}{*}{$\begin{array}{l}\text { Public } \\
\text { administration }\end{array}$} & & $0.034 * * *$ & $0.055 * * *$ & $0.035 * * *$ \\
\hline & & $(0.012)$ & $(0.018)$ & $(0.012)$ \\
\hline \multirow[t]{2}{*}{ Education } & & $-0.024 * * *$ & $-0.027 * * *$ & $-0.024 * * *$ \\
\hline & & $(0.005)$ & $(0.006)$ & $(0.005)$ \\
\hline \multirow[t]{2}{*}{ Science and culture } & & $0.095 * * *$ & $0.104^{* * *}$ & $0.096 * * *$ \\
\hline & & $(0.015)$ & $(0.020)$ & $(0.016)$ \\
\hline \multirow[t]{2}{*}{ Health } & & 0.008 & $0.022 * *$ & 0.009 \\
\hline & & $(0.007)$ & $(0.011)$ & $(0.007)$ \\
\hline \multirow[t]{2}{*}{ Defence } & & -0.001 & 0.011 & -0.001 \\
\hline & & $(0.008)$ & $(0.012)$ & $(0.008)$ \\
\hline \multirow{2}{*}{$\begin{array}{l}\text { Trade, related } \\
\text { services }\end{array}$} & & $0.133^{* * *}$ & $0.150 * * *$ & $0.134^{* * *}$ \\
\hline & & $(0.012)$ & $(0.015)$ & $(0.012)$ \\
\hline \multirow[t]{2}{*}{ Finance } & & $0.038 * * *$ & $0.039 * *$ & $0.035 * *$ \\
\hline & & $(0.014)$ & $(0.019)$ & $(0.014)$ \\
\hline \multirow[t]{2}{*}{ Energy ind. } & & $-0.017^{*}$ & -0.004 & $-0.017 *$ \\
\hline & & $(0.010)$ & $(0.015)$ & $(0.010)$ \\
\hline \multirow[t]{2}{*}{ Housing } & & $0.038 * * *$ & $0.041 * * *$ & $0.038 * * *$ \\
\hline & & $(0.012)$ & $(0.015)$ & $(0.012)$ \\
\hline \multirow[t]{2}{*}{ Other ind. } & & $0.128 * * *$ & $0.150 * * *$ & $0.132 * * *$ \\
\hline & & $(0.020)$ & $(0.031)$ & $(0.021)$ \\
\hline \multirow{2}{*}{$\begin{array}{l}\text { Legislators, senior } \\
\text { managers, officials }\end{array}$} & & $0.091 * * *$ & $0.086 * * *$ & $0.091 * * *$ \\
\hline & & $(0.012)$ & $(0.014)$ & $(0.012)$ \\
\hline \multirow[t]{2}{*}{ Professionals } & & 0.007 & 0.004 & 0.008 \\
\hline & & $(0.006)$ & $(0.007)$ & $(0.006)$ \\
\hline \multirow{2}{*}{$\begin{array}{l}\text { Assoc. Profess. } \\
\text { with sec. spec. ed. }\end{array}$} & & 0.006 & -0.000 & 0.007 \\
\hline & & $(0.005)$ & $(0.006)$ & $(0.005)$ \\
\hline \multirow[t]{2}{*}{ Clerks } & & $0.013^{*}$ & 0.004 & $0.012 *$ \\
\hline & & $(0.007)$ & $(0.008)$ & $(0.007)$ \\
\hline \multirow[t]{2}{*}{ Service workers } & & $0.101 * * *$ & $0.087 * * *$ & $0.101 * * *$ \\
\hline & & $(0.010)$ & $(0.011)$ & $(0.010)$ \\
\hline \multirow{2}{*}{$\begin{array}{l}\text { Skilled agricultural } \\
\text { and fishery workers }\end{array}$} & & $0.145^{* * *}$ & $0.191^{* * *}$ & $0.147 * * *$ \\
\hline & & $(0.039)$ & $(0.061)$ & $(0.040)$ \\
\hline \multirow{2}{*}{$\begin{array}{l}\text { Craft and related } \\
\text { trades }\end{array}$} & & $0.024^{* * *}$ & $0.024^{* * *}$ & $0.024^{* * *}$ \\
\hline & & $(0.007)$ & $(0.009)$ & $(0.007)$ \\
\hline \multirow{2}{*}{$\begin{array}{l}\text { Plant / Machine } \\
\text { operators/Ind. w-s }\end{array}$} & & -0.001 & -0.003 & -0.000 \\
\hline & & $(0.005)$ & $(0.006)$ & $(0.005)$ \\
\hline Observations & 40049 & 36169 & 22784 & 35787 \\
\hline
\end{tabular}

Notes: Robust standard errors in parentheses. * significant at 10\%; ** significant at 5\%; *** significant at $1 \%$.

Reference categories are: female, not married, primary education level, Moscow/St. Petersburg, large regional center, non-immigrants, year 2004, Light and food industry, Unskilled workers. 
Table A7: Hourly wage gap: Informal employees. Based on average monthly wage over the last 12 months, main job

\begin{tabular}{|c|c|c|c|c|c|c|}
\hline & (1) & $\begin{array}{l}(2) \\
\text { OLS }\end{array}$ & (3) & (4) & $\begin{array}{l}(5) \\
\text { FE }\end{array}$ & (6) \\
\hline Informal employee & $\begin{array}{c}-0.088 * * * \\
(0.012)\end{array}$ & $\begin{array}{c}-0.111 * * * \\
(0.012)\end{array}$ & $\begin{array}{c}-0.062^{* * *} \\
(0.012)\end{array}$ & $\begin{array}{c}0.005 \\
(0.016)\end{array}$ & $\begin{array}{l}-0.006 \\
(0.017)\end{array}$ & $\begin{array}{l}-0.001 \\
(0.017)\end{array}$ \\
\hline Age & $\begin{array}{c}0.034 * * * \\
(0.002)\end{array}$ & $\begin{array}{c}0.033^{* * *} \\
(0.002)\end{array}$ & $\begin{array}{c}0.030 * * * \\
(0.002)\end{array}$ & $\begin{array}{c}0.074 * * * \\
(0.012)\end{array}$ & $\begin{array}{c}0.071 * * * \\
(0.013)\end{array}$ & $\begin{array}{c}0.069 * * * \\
(0.013)\end{array}$ \\
\hline Age squared & $\begin{array}{c}-0.000^{* * * *} \\
(0.000)\end{array}$ & $\begin{array}{c}-0.000^{* * *} \\
(0.000)\end{array}$ & $\begin{array}{c}-0.000^{* * * *} \\
(0.000)\end{array}$ & $\begin{array}{c}-0.001^{* * *} \\
(0.000)\end{array}$ & $\begin{array}{c}-0.001^{* * * *} \\
(0.000)\end{array}$ & $\begin{array}{c}-0.001^{* * *} \\
(0.000)\end{array}$ \\
\hline Male & $\begin{array}{c}0.322 * * * \\
(0.005)\end{array}$ & $\begin{array}{l}0.252 * * * \\
(0.006)\end{array}$ & $\begin{array}{c}0.228 * * * \\
(0.006)\end{array}$ & & & \\
\hline Married & $\begin{array}{c}0.042 * * * \\
(0.006)\end{array}$ & $\begin{array}{l}0.039 * * * \\
(0.006)\end{array}$ & $\begin{array}{c}0.033^{* * *} \\
(0.006)\end{array}$ & $\begin{array}{c}0.006 \\
(0.011)\end{array}$ & $\begin{array}{c}0.008 \\
(0.012)\end{array}$ & $\begin{array}{c}0.010 \\
(0.012)\end{array}$ \\
\hline Sec. edu. & $\begin{array}{c}0.162 * * * \\
(0.008)\end{array}$ & $\begin{array}{c}0.138 * * * \\
(0.008)\end{array}$ & $\begin{array}{c}0.089 * * * \\
(0.008)\end{array}$ & $\begin{array}{l}-0.001 \\
(0.019)\end{array}$ & $\begin{array}{l}-0.001 \\
(0.020)\end{array}$ & $\begin{array}{c}0.001 \\
(0.020)\end{array}$ \\
\hline Higher edu. & $\begin{array}{c}0.501^{* * *} \\
(0.009)\end{array}$ & $\begin{array}{c}0.484 * * * \\
(0.009)\end{array}$ & $\begin{array}{c}0.296 * * * \\
(0.010)\end{array}$ & $\begin{array}{l}0.050^{*} \\
(0.030)\end{array}$ & $\begin{array}{c}0.026 \\
(0.030)\end{array}$ & $\begin{array}{c}0.017 \\
(0.030)\end{array}$ \\
\hline City & $\begin{array}{c}-0.113^{* * *} \\
(0.006)\end{array}$ & $\begin{array}{c}-0.125^{* * *} \\
(0.006)\end{array}$ & $\begin{array}{c}-0.127^{* * * *} \\
(0.006)\end{array}$ & & & \\
\hline Village & $\begin{array}{c}-0.430 * * * \\
(0.007)\end{array}$ & $\begin{array}{c}-0.315^{* * *} \\
(0.008)\end{array}$ & $\begin{array}{c}-0.301 * * * \\
(0.007)\end{array}$ & & & \\
\hline Region dummies & Yes & Yes & Yes & Yes & Yes & Yes \\
\hline Year dummies & Yes & Yes & Yes & Yes & Yes & Yes \\
\hline Sector dummies & No & Yes & Yes & No & Yes & Yes \\
\hline Occupations dummies & No & No & Yes & No & No & Yes \\
\hline Constant & $\begin{array}{c}2.817 * * * \\
(0.033)\end{array}$ & $\begin{array}{l}2.873 * * * \\
(0.035)\end{array}$ & $\begin{array}{c}2.734 * * * \\
(0.034)\end{array}$ & $\begin{array}{c}1.625^{* * *} \\
(0.390)\end{array}$ & $\begin{array}{c}1.252^{* * *} \\
(0.363)\end{array}$ & $\begin{array}{c}1.603^{* * *} \\
(0.412)\end{array}$ \\
\hline Observations & 46754 & 42414 & 42358 & 46754 & 42414 & 42358 \\
\hline $\begin{array}{l}\text { R-squared } \\
\text { Number of groups }\end{array}$ & 0.54 & 0.54 & 0.57 & $\begin{array}{c}0.58 \\
15087\end{array}$ & $\begin{array}{c}0.53 \\
14410\end{array}$ & $\begin{array}{c}0.54 \\
14398\end{array}$ \\
\hline
\end{tabular}

Notes: Robust standard errors in parentheses. ${ }^{*}$ significant at $10 \%$; $* *$ significant at $5 \%$; *** significant at $1 \%$. 


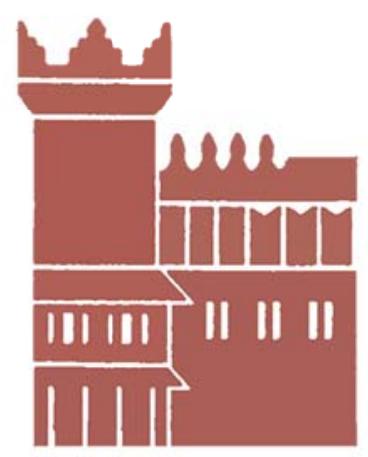

Alma Mater Studiorum - Università di Bologna DEPARTMENT OF ECONOMICS

Strada Maggiore 45

40125 Bologna - Italy

Tel. +39051 2092604

Fax +390512092664

http://www.dse.unibo.it 